\title{
Geologic Map of Nevada
}

By A. Elizabeth Jones Crafford'

With a section on A Digital Conodont Database of Nevada

By Anita G. Harris² and A. Elizabeth Jones Crafford ${ }^{1}$

Prepared in cooperation with the Nevada Bureau of Mines and Geology

Pamphlet to accompany Data Series 249

${ }^{1}$ GeoLogic, 9501 Nettleton Drive, Anchorage, Alaska

${ }^{2}$ U.S. Geological Survey, Denver, Colo. 


\title{
U.S. Department of the Interior DIRK KEMPTHORNE, Secretary
}

\section{U.S. Geological Survey \\ Mark D. Myers, Director}

\author{
U.S. Geological Survey, Reston, Virginia: 2007 \\ Version 1.0
}

For sale by U.S. Geological Survey Information Services

Box 25286, Denver Federal Center

Denver, Colo. 80225

For more information about the USGS and its products:

Telephone: 1-888-ASK-USGS

World Wide Web: http//www.usgs.gov/

Any use of trade, product, or firm names in this publication is for descriptive purposes only and does not imply endorsement by the U.S. Government.

Although this report is in the public domain, permission must be secured from the individual copyright owners to reproduce any copyrighted materials contained within this report.

Suggested citation:

Crafford, A.E.J., 2007, Geologic Map of Nevada: U.S. Geological Survey Data Series 249,

1 CD-ROM, 46 p., 1 plate.

\section{Library of Congress Cataloging-in-Publication Data}

Crafford, A. Elizabeth Jones,

Geologic Map of Nevada

p. cm. -(U.S. Geological Survey data series ; 249)

Includes bibliographic references.

1. Geology—Nevada. 


\section{Contents}

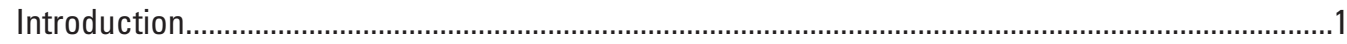

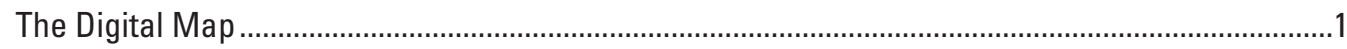

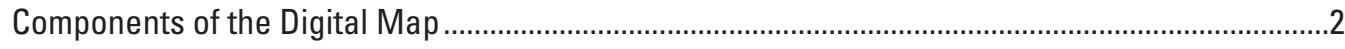

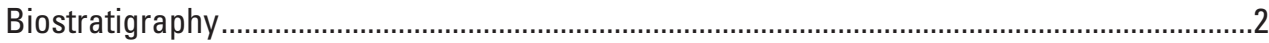

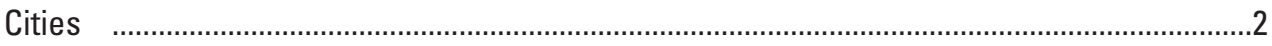

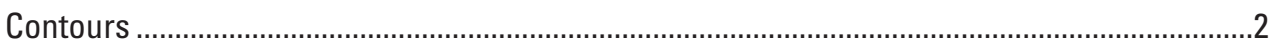

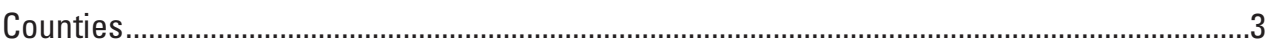

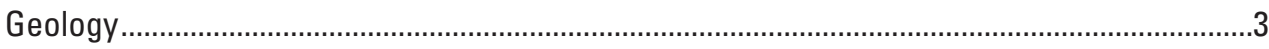

Lakes

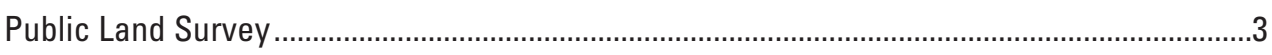

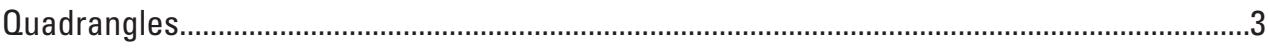

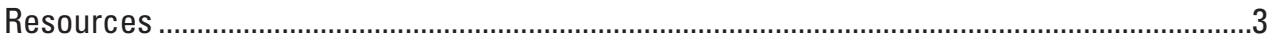

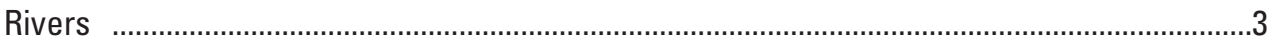

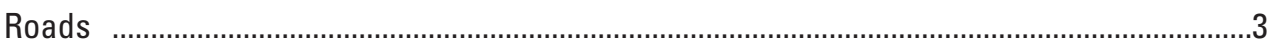

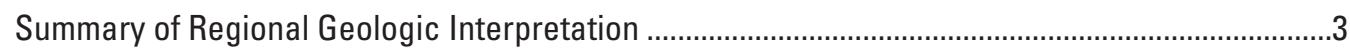

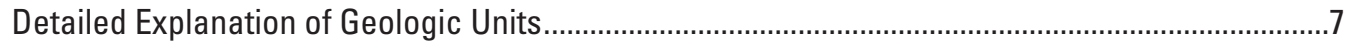

Quaternary Sediments and Rocks (Holocene and Pleistocene) ...............................................

Sediments and Sedimentary Rocks .............................................................................

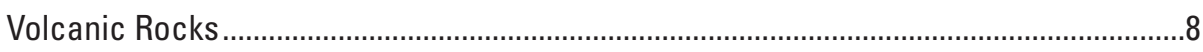

Quaternary and Pliocene Sediments and Rocks ...............................................................8

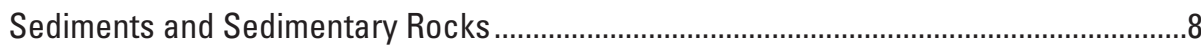

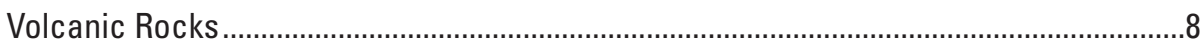

Tertiary and Upper Cretaceous(?) Rocks............................................................................

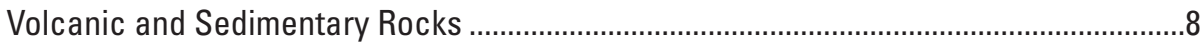

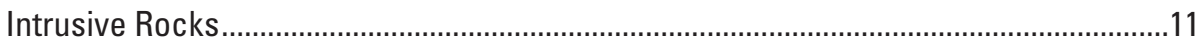

Miocene(?) to Jurassic(?) Intrusive Rocks..............................................................................11

Mesozoic Intrusive and Volcanic Rocks.................................................................................11

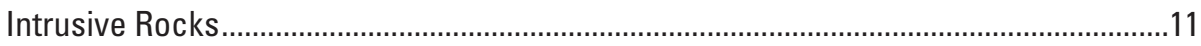

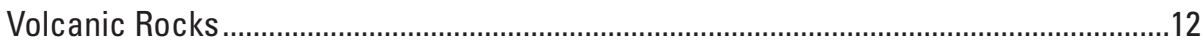

Mesozoic Terranes, Sedimentary Rocks, and Assemblages .................................................13

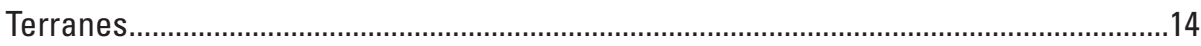

Walker Lake Terrane ........................................................................................... 14

Black Rock-Jackson Terrane............................................................................. 15

Sand Springs Terrane............................................................................................ 15

Quartz Mountain Terrane.................................................................................. 16

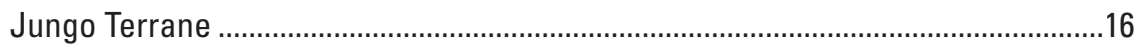

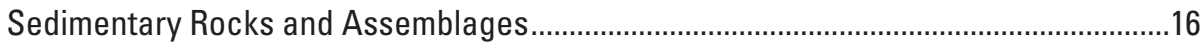

Localized Clastic Rocks ..................................................................................... 16

Gold Range Assemblage ........................................................................................... 17

Humboldt Assemblage ............................................................................................. 18

Siliciclastic Overlap Assemblage ...................................................................... 18

Cratonal Sequence ........................................................................................... 19 


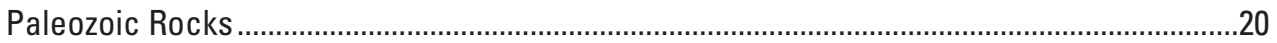

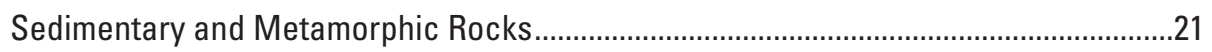

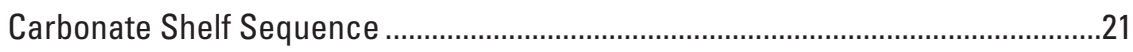

Undivided and Metamorphosed Carbonate Shelf Sequence Rocks........................24

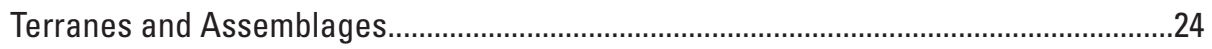

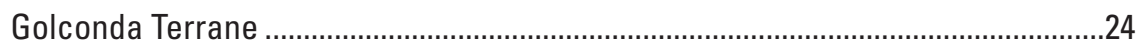

Siliciclastic Overlap Assemblage ...................................................................26

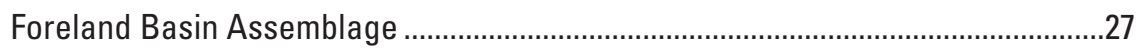

Dutch Flat Terrane .................................................................................................

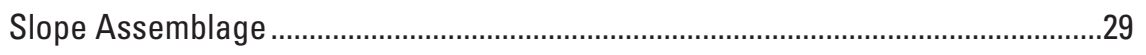

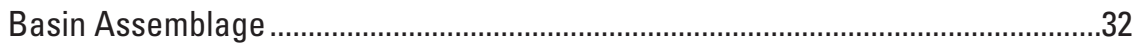

Nolan Belt .........................................................................................................

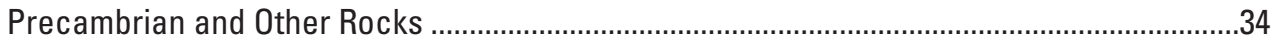

Lower Cambrian to Latest Proterozoic Clastic Rocks ....................................................34

Proterozoic Basement Rocks ......................................................................................35

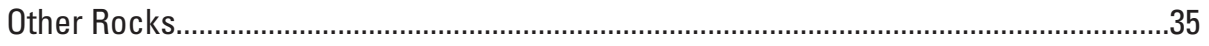

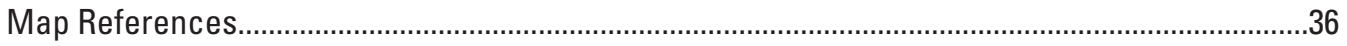

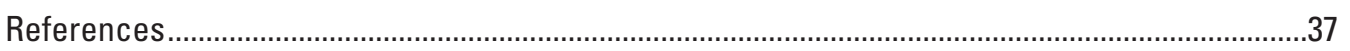

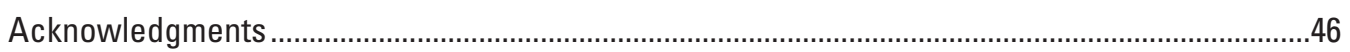




\title{
Geologic Map of Nevada
}

\author{
By A. Elizabeth Jones Crafford'
}

\section{Introduction}

The purpose of the Geologic Map of Nevada is to provide an integrated set of digital geologic information that can be used for regional geologic and rigorous spatial analysis. Two components of this map represent new information that has not been published in this form before. The new geology layer was created by merging into a single file individual digital Nevada county geologic maps (Hess and Johnson, 1997), published at a scale of 1:250,000. A new regional interpretation was created to unify all of the different county rock units, and then appropriate edits and modifications were made to the file to reflect additional geologic information and more current geologic interpretations. All possible sources of information were not utilized in the scope of this project, but rather the goal was to create a consistent Statewide 1:250,000scale map that would facilitate regional geologic interpretation and be a foundation for future spatial analyses of digital data. Secondly, a new database of conodont biostratigraphic data compiled and analyzed by Anita Harris is also incorporated into the map. Information about many, but not all, of these conodont samples have been published separately elsewhere over the years, but they have not been presented together in a single digital database. Other previously published data layers are used in this map to enhance the usefulness of the geologic information. These layers include mineral deposit locations, oil well locations, and cartographic layers such as county boundaries, roads, towns, cities, rivers, water bodies, township, range and section grids, quadrangle grids, and topography. A summary of these components is given below, and complete descriptions of each layer are provided in the digital metadata.

\section{The Digital Map}

The necessary first step to create the Geologic Map of Nevada was creation of digital polygon and line coverages from the original published county geologic maps. This was done by the Nevada Bureau of Mines and Geology (NBMG)

${ }^{1}$ GeoLogic, 9501 Nettleton Drive, Anchorage, Alaska 99507; ecrafford@Alaska.com in 1996 (Hess and Johnson, 1997). Their careful creation of over 34,000 polygons of geology made possible the next step of integrating together geologic information from the different maps into a new, unified explanation. The 16 different geologic maps were created over a time span of more than 20 years by different people using different geologic standards, but all at a scale of 1:250,000. Remarkably, in spite of the large number of contributors over such a long period of time, the locational accuracy of the basic geologic polygon boundaries are good to excellent, with only a few areas needing significant modification. Interpretations of the units, however, vary significantly, and some required substantial modification on the basis of newer information, ideas, and interpretations. A new regional interpretation of the geology of Nevada is presented with this map and applied to the polygons from the county maps. The interpretation draws on the work of many, including the original State geologic map (Stewart, 1980; Stewart and Carlson, 1978). This new regional interpretation resulted in combining the thousand plus different units used on the county maps into just over 100 Statewide units. In addition to geology polygons, boundaries of the polygons with their attributes and fault traces were combined from the multiple county maps into individual Statewide layers, but they were not edited for this project. The user of the map will benefit greatly from studying the accompanying explanation presented as a separate document "Explanation for Geologic Map of Nevada.pdf."

The benefits of a digital map are many. The user can easily choose layers to turn on or off, modify those layers to suit their needs, and display or print information of particular interest at a particular scale. A digital map also introduces important caveats and responsibilities of which the user must be aware. The only layer of this map that has been spatially edited (the boundaries of the polygons themselves have been altered in some cases, and new polygons have been created) is the geology polygon layer (NevadaGeology.shp). The other two geology layers, the faults layer, and the geologic boundaries layers have not been edited yet to match the new geology polygon boundary layers. Therefore, in places where the geology has been edited, the boundaries of the polygons will no longer match the lines associated with the faults layer or the boundaries layer. Additionally, there are cases where one existing polygon was split into numerous pieces to improve either the location or interpretive accuracy of the 
map, with the different pieces being assigned to different units. This procedure results in a more accurate display of the geology, but also introduces spurious boundaries that have no geologic meaning. The boundaries are transparent, but the user needs to be aware that an area of a single geologic unit may be composed of several adjoining polygons. Hopefully a future release of this map will be able to address these challenging issues. These concerns, however, only apply to approximately 10 percent of the polygons on the map, and thus most boundary and fault lines still agree with the geology polygons, and should not affect general use of the map.

When combining layers of data from different sources, such as biostratigraphic or radiometric data with the geologic data, inherent variation of the spatial accuracy of the raw data from the different layers will not always match as expected. Location inaccuracies in point samples, map-scale inaccuracies of geologic polygons, and many other factors make this a significant issue. For this first release of the digital map, geologic and biostratigraphic layers are not all reconciled-in other words, for example, some Devonian conodonts plot in alluvium adjacent to the Devonian rock unit from which they were sampled, not within the boundaries of the polygon as expected. With continued support, resolution of these discrepancies is a primary goal for future releases of the map, so that data will be fully integrated and benefits of an ArcGIS system can be utilized to carry out true spatial analyses of the data. Attributes in both the geology and biostratigraphy layers attempt to document the discrepancies with the future hope of resolving them.

An important benefit of a digital map is that any number of attributes can be attached to any spatial object. This means that information about a specific polygon, such as boundary edits or value changes can easily be attached to that feature to help the user interpret the information. The user should take advantage of the many annotations included as attributes to the individual polygons explaining reference details, discrepancies, and unsolved problems for that particular polygon when interpreting the geology. The metadata that accompanies the geology file (NevadaGeology.shp) has a complete explanation of all the attributes and the meaning of their values.

The only component of the map that is ready for rigorous spatial analysis is the geology polygon layer (NevadaGeology. shp) using the GEOLOGICFM attribute field. If the user wishes to create topology for the file, they will have to input a $0.1 \mathrm{~m}$ cluster tolerance in order to have an error free file. Additionally, for conversion to a raster file, grouping of the Quaternary units Qya and Qal will be required to eliminate significant county boundary discontinuities. Other minor discontinuities are discussed in the file metadata.

\section{Components of the Digital Map}

To provide context for the geologic information, additional layers of geographic and geologic information are also portrayed on the map. A brief description of each of the map's components is provided below under a heading that matches the folder on the $\mathrm{CD}$ that contains the data. A complete listing of the files in each folder is provided in the accompanying Readmefile.txt document. Additional details including descriptions of all the attributes for each data set are provided in the metadata accompanying each data file. To access the digital map and metadata, the user needs ArcGIS 9.x software, and should open the NevadaStateDigitalGeologicMap.mxd file included on the CD-ROM. The map is accessed through ArcMap, and the .xml metadata files can be viewed through ArcCatalog.

\section{Biostratigraphy}

The biostratigraphic information presented here consists of 2,617 conodont sample locations from A.G. Harris ${ }^{2}$, U.S. Geological Survey (USGS), emeritus in a shapefile called ConodontSamples.shp. They represent samples collected by many individuals over many years, and examined by Anita Harris. Sample locations were provided by Harris and except for a handful have not been verified for this publication. Information about many, but not all, of these samples has been published over the years in various maps and other publications, and references to USGS reports are given in the attribute table. Conodont data are displayed in seventeen different layers in the project. Fifteen layers have data broken out by sample age or age range, and colored by Conodont Color Alteration Index Minimum (CAImin) value. One layer shows samples taken from the subsurface such as drill holes or underground mine workings. Another single layer shows all of the conodonts, not differentiated by time, colored by their CAImin value. Each age or age range has a different color rim on the symbol or a different shape symbol. The CAI color scale used is intended to mimic the actual conodont color. Explanation of all the attributes for the conodont data is provided in the metadata for the file.

\section{Cities}

The CITIES_P.shp shapefile provided by the Nevada Bureau of Mines and Geology is a layer showing 101 point locations for Nevada cities and towns at 1:1,000,000 scale.

\section{Contours}

The CTOUR2.shp shapefile is a layer consisting of 150 $\mathrm{m}, 2$-arc-second contours that were derived from the DLG map of Nevada, and created at the Nevada Bureau of Mines and Geology by the author and Ron Hess.

${ }^{2}$ U.S. Geological Survey, Box 25046, Denver Federal Center, Mail Stop 973, Denver, Colo. 80225-0046; aharris@usgs.gov 


\section{Counties}

NEVADACOUNTIES.shp is a shapefile of Nevada counties with the latest boundary locations updated. It was provided by the Nevada Department of Transportation in 2006.

\section{Geology}

Three different layers are used for the primary geologic information. All are shapefiles. The geology polygon file, NevadaGeology.shp has attributes to describe each of the polygons used on the map. The geologic boundaries shapefile (StatewideGeoBoundaries.shp) describes the characteristics of the boundaries of the geology polygons, such as whether they are known, inferred, faulted, concealed, or map boundaries. The faults layer is the shapefile StatewideFaults.shp and shows all the faults from the county maps, attributed by type of fault. The faults and boundaries layers have not been edited from their original digital version created by NBMG except to combine them into a single Statewide file. This means that in places where the geology polygon boundaries have been edited, they will no longer match the fault or contact boundaries. This only affects about 10 percent of the geology polygons. The original contact boundaries still need to be displayed (instead of the new ones) because they are attributed to make the map boundary lines invisible. While efforts have been made to check that the representation of the fault attributes is correct (such as upper plate and lower plate symbology) it has not been comprehensively examined. Errors observed should be brought to the author's attention. A summary of the geologic interpretation and details of the meaning of the codes used in the GEOLOGICFM field are provided in this document. Layer files (.lyr) have been created for virtually all layers to preserve the symbology associated with a given layer, especially the layout of all of the geologic units.

\section{Lakes}

Water bodies taken from the 1:100,000-scale topographic maps were compiled into a shapefile, lake_100.shp by the Nevada Natural Heritage Program of the Department of Conservation and Natural Resources. The geology layer (NevadaGeology.shp) includes 23 polygons attributed as water bodies (WBDY). They are not displayed on the geology layer shown in the project. The user will see a much more accurate representation of the water bodies in the State by turning on the Water Bodies layer.

\section{Public Land Survey}

The township and range grid is shapefile tr100grid.shp, and the section grid is shapefile plss 100k.shp. These data sets were created and provided by the U.S. Bureau of Land Management (BLM).

\section{Quadrangles}

Two quadrangle files are included. The 1:100,000-scale quadrangles shapefile, nv_100kquads.shp, provided by the BLM, and 7.5' (1:24,000-scale) quadrangle shapefile, NVQDP. shp, provided by the USGS.

\section{Resources}

Two different resource layers are included, Oil Wells and Gold Deposits. The Oil Wells are plotted from an edited version of a .dbf file provided by the Nevada Bureau of Mines and Geology, OFR04_1. It is current to June 2004. The SHOWEDIT attribute was cleaned up to remove duplication and symbolized. The mineral deposit information is taken from the USGS data file of MRDS deposits, mrds-fUS32.shp, now available online, updated from the 2000 version in 2005. Only those deposits that are designated as Model 19c, distaldisseminated $\mathrm{Ag}-\mathrm{Au}$, or Model 26a carbonate-hosted Au-Ag (Bliss, 1992; Cox and Singer, 1992) are currently displayed on the map, but the user can modify the display as needed by changing the definition query to show any of the Nevada sites and multiple deposit models.

\section{Rivers}

The perennial and intermittent rivers and streams in Nevada are displayed with the RIVER_TYPE attribute from the nevadarivers.shp shapefile provided by the Nevada Bureau of Mines and Geology.

\section{Roads}

The primary roads in Nevada are shown in the roads layer, ROADS_A.shp shapefile provided by the Nevada Bureau of Mines and Geology.

\section{Summary of Regional Geologic Interpretation}

A twofold challenge of creating this map was to combine the 1,000 plus county map geologic units into slightly more than 100 regional units while modifying the overall regional geologic interpretation from the original ideas in Stewart and Carlson (1978) to reflect new data and ideas. The value of a digital product is that it provides opportunity for trial and experimentation, allowing for as much iteration as necessary to create an interpretation that is as consistent with the data as possible. Many iterations were required for this interpretation.

The new regional geologic interpretation is visually presented in the accompanying file "Explanation for Geologic Map of Nevada.pdf," and discussed in this text. A separate interpretation of the tectonic history of the region is presented 
elsewhere. The rock unit designations for this new map include stratigraphic units as well as assemblages and terranes. This method was deliberately chosen to reflect more clearly both the stratigraphic and tectonic history of these rocks as an inherent component of the unit. It is the combination of lithologic and structural characteristics, not one or the other, that define a unit as distinct from other groups of rocks. The third variable in regional interpretation is always the incompleteness of our understanding of the basic geologic data in many places, which contributes significantly to how they can be reasonably grouped.

Quaternary to Pliocene sediments and rocks reflect more inconsistency from county to county than rock units from most other age periods. Some counties differentiated older and younger alluvium and some did not, so two units were used but not always designated in each county (Qal, Qya). Sand dunes, playas, and glacial moraines are also included as Quaternary units (Qs, Qpl, Qg). Only one Quaternary volcanic unit, basalt flows, $(\mathrm{Ob})$ is designated. Quaternary and Pliocene sediments and sedimentary rocks include hot spring deposits (OThs), landslide deposits (OTIs), older gravels (QTg), older alluvium (QToa), and volcaniclastic sediments (QTs). Apart from the Quaternary basalt, the youngest volcanic rocks in the State include late Tertiary or early Quaternary basalt flows (QTb), andesite (QTa), and rhyolite (QTr).

Most Tertiary rocks in Nevada are volcanic. Lacustrine, fluvial, and tuffaceous sedimentary rocks were deposited in Tertiary (and possibly Upper Cretaceous) basins scattered around the State. The classification of the Tertiary volcanic and sedimentary rocks in this map follows closely the scheme used in Stewart and Carlson (1978) with a few consolidations supported by new information. There are three age groupings, from youngest to oldest, T3 (6-17 Ma), T2 (18-34 Ma), and T1 (35-43). There are five primary compositional and (or) textural groupings for the volcanic and sedimentary rocks: sedimentary (Ts3, Ts2, TKs1), basaltic (Tb3, Tb2), andesitic (Ta3, Ta2, Ta1), tuffaceous (Tt3, Tt2, Tt1) and rhyolitic (Tr3, Tr2, Tr1). In addition, a few Tertiary units (Tba, Tbg, Ths) are present that cross time and compositional boundaries, and they are designated separately. Tertiary intrusive rocks are shown as phaneritic felsic or mafic composition (Tfi, Tmi), or aphanitic rhyolite (Tri). Mafic or felsic intrusive rocks of unknown age are mapped separately from Tertiary and Mesozoic intrusions (TJmi, TJfi).

Mesozoic intrusive, volcanic, sedimentary, and metamorphic rocks, including those associated with accreted terranes are all present in Nevada. These rocks formed in a variety of tectonic environments and depositional settings-they reflect many diverse structural and tectonic histories. A few Triassic ( $\mathrm{kfi}$ ), and numerous Jurassic (Jgb, Jmi, Jfi, Ji) and Cretaceous (Kmi, Kfi, Ki) plutons of mafic, felsic, and unknown compositions are scattered across the State, with a concentration near the Sierra Nevada Mountains associated with the Mesozoic arcs. Triassic ( $\mathrm{k} v \mathrm{~m}, \mathrm{k} k \mathrm{v}$ ), Jurassic (Jvr, Jvb), and Jurassic(?) and Triassic(?) age (JkV) volcanic rocks also range in composition from felsic to mafic and are spread across the central part of the State. Their tectonic settings and origins are not well understood, but they are likely related to the Triassic and Jurassic arc complexes, and possibly also to the accreted terranes.

Ten different groupings of Mesozoic terranes, sedimentary rocks and assemblages are recognized. They include clastic rocks and conglomerates that unconformably overlie older, folded and faulted rocks, distinct stratigraphic sequences in the southern, eastern, and central parts of the State, and numerous different assemblages with distinct stratigraphic and structural histories that are juxtaposed in several different terranes along tectonic boundaries in the western half of the State. Mesozoic sedimentary rocks are difficult to classify because of the diversity of their structural histories, depositional settings, and basements coupled with our incomplete knowledge of their relations to each other. Generally, they can be grouped into two categories-those sequences that are deposited on a known basement, and those sequences that are strongly disrupted and their basement is either unknown or intimately deformed along with them as part of a larger terrane. In places where Mesozoic rocks have a complex deformation history, they are not grouped by formation, but rather are grouped as either terranes or assemblages. Terranes are used in the classic sense for fault-bounded geologic entities of regional extent, each characterized by a geologic history that is different from the histories of contiguous terranes (Jones, Howell, and others, 1983). Assemblage is used for a group of related rock units within a terrane, or for a unit (or units) that has a known basement, but is geographically isolated and lithologically and (or) structurally distinct from other coeval rocks. This can result in formation names being used across assemblages, but it provides a clearer picture of regional tectonic groupings of the rocks. This, in turn, provides the framework for understanding the overall tectonic evolution of these rocks and how their complex relations to one another have evolved over time. The groupings used here generally follow earlier terrane maps and discussions (Silberling, 1991; Silberling, Jones, and others, 1987; Silberling, Jones, and others, 1992) although several modifications have been made to reflect additional information. The groupings are displayed in the accompanying map sheet "Explanation of Geologic Map of Nevada.pdf."

The disrupted rocks with unknown basement include those in:

- the Walker Lake terrane composed of Mesozoic carbonate, siliclastic, volcanic, and volcaniclastic rocks in Lyon, Mineral, and western Nye Counties which is divided into three distinct assemblages (WPN, WPL, WLB),

- the Black Rock-Jackson terrane (BRJ) that includes Mississippian to Middle Jurassic carbonate, clastic, and volcaniclastic rocks,

- the Sand Springs terrane (SAS), which extends from the northwestern corner of Nye County northwest into 
Washoe County, consisting mostly of volcanic rocks of Late Triassic and Early Jurassic age,

- the Quartz Mountain terrane (OM), a structurally disrupted unit of unknown Mesozoic or Paleozoic age in Churchill and northern Nye Counties, which is distinguished lithologically by the association of orthoquartzite with feldspathic sandstone and (or) volcanic rocks, and

- the Jungo terrane (JO) in west-central and northwestern Nevada consisting of Triassic to Lower Jurassic fine-grained terrigenous clastic rocks.

All of the rocks of these terranes have experienced varying degrees of deformation and metamorphism, and have complex tectonic histories.

The rocks that are deposited on a known basement include:

- Localized clastic rocks (TKcg, $\mathrm{Kcg}, \mathrm{Jcg}$ ) scattered in several places across the State,

- the Gold Range assemblage (Jkgor) in Mineral and western Nye Counties,

- the Humboldt assemblage ( $\mathrm{kc}, \mathrm{Jks}$ ) in a large area of Pershing, Churchill, and Lander Counties,

- the Candelaria Formation ( $\mathrm{Kcl}$ ) of the Siliciclastic overlap assemblage best exposed south of Mina, and

- the Cratonal sequence ( $\mathrm{kmt}, \mathrm{J} \mathrm{kch}$, Jas) in the eastern and southern parts of the State.

Interpretation of Paleozoic rocks in Nevada has had a long and colorful history. Paleozoic rocks in Nevada are grouped into six categories that include stratigraphic sequences and lithologic assemblages, and three accreted terranes. These groupings were chosen to best represent the similarities and differences among different rock units, and are shown in the accompanying explanation. The sequence and assemblages are:

- In the eastern third of the State, the Carbonate shelf sequence (Pc, Psc, PPc, PMbc, Mc, Dc, Dcd, DSc, SOc, Ocq, O€c, $€ c$ ) includes Cambrian through Permian sedimentary rocks and their metamorphosed or undivided equivalents (D€c, DOcm, Ocqm,

$O € \mathrm{~cm}$ ). While these rocks have seen significant postPaleozoic disruption in places, the regional pattern of these rocks is one of either continuous conformable or disconformable sequences. Major unconformities are not part of this sequence. The Carbonate shelf sequence lies conformably on Precambrian to Lower Cambrian quartzite.

- The Siliciclastic overlap assemblage ( $\mathrm{kcl}, \mathrm{Pacl}$, PPacl) is a Pennsylvanian through Lower Triassic sequence of siliciclastic and carbonate rocks lying above a major unconformity. Rocks of this assemblage unconformably overlie rocks of the Carbonate shelf sequence, the Foreland basin assemblage, lower Paleozoic rocks of the Slope and Basin assemblages, the Nolan belt, and the Dutch Flat terrane. Its sparse regional distribution but consistent stratigraphic (and structural) position makes it an important regional tectonic constraint. Lower Triassic rocks of the Siliciclastic overlap assemblage ( $\mathrm{kcl}$ ) are only exposed in southwestern and south-central Nevada, and their relation to the underlying unit $\mathrm{Pacl}$ is unclear but inferred to be depositional.

- The Foreland basin assemblage (PMcl, MDcl) is an Upper Devonian through Lower Pennsylvanian siliciclastic sequence deposited on the western part of the Carbonate shelf sequence. There may be unconformities within the Foreland basin assemblage, but much of the sequence is conformable or disconformable, and lithologies above and below any breaks are similar, making them difficult to identify.

- In a north-south belt in the east-central part of the State, Ordovician through Lower Mississippian rocks are grouped into the Slope assemblage (MDst, DSt, DOts). Parts of this assemblage are in conformable depositional contact with Carbonate shelf sequence rocks, and fairly coherent stratigraphic sequences can be defined. In most places, however, these rocks are imbricated in thrust sheets with rocks of both the Carbonate shelf sequence and the Basin assemblage. The lithologies of the Slope assemblage reflect both slope and basin depositional settings.

- Rocks of the Basin assemblage (D€s, Ss) are exposed in a belt trending southwest and south from northeastern Nevada towards Esmeralda County. These Upper Cambrian through Devonian rocks are characteristic of deep marine and base-of-slope paleogeographic settings and include both sedimentary rocks and occasionally their mafic volcanic substrate. Apart from fragments of basaltic rocks, no true basement is preserved along with these rocks, and they are everywhere structurally emplaced over other generally coeval rocks. They are imbricated with Carbonate shelf sequence rocks, Slope assemblage rocks, and rocks of the Nolan belt. The amount of displacement experienced by the rocks in this assemblage is unknown and likely highly variable.

- A belt of lower Paleozoic rocks with affinity to the continental margin but with unusual structural characteristics forms a discrete belt west and northwest of displaced rocks of the Slope and Basin assemblages, and is here named the Nolan belt. They are different from the other Paleozoic rocks in a number of important ways that warrant distinction as a separate group. These rocks have structural characteristics of 
an accreted terrane, that is, they exhibit polyphase deformation, but have stratigraphic ties to North America that suggest they have not traveled great distances laterally from the continental margin. The three principal characteristics that define the Nolan belt of rocks are that (1) lithologically they define a region of outer shelf and slope Cambrian and Ordovician rocks, originally deposited in a more proximal position to the Carbonate shelf sequence than the rocks of the Basin assemblage, some of which now lie structurally to the east of this belt, (2) unlike rocks of the Basin or most of the Slope assemblage, they are stratigraphically attached to their Precambrian to Cambrian quartzite basement, and (3) they exhibit a unique polyphase deformation history distinct from adjacent coeval rocks.

Three accreted terranes are defined for the Paleozoic rocks, including the Black Rock-Jackson terrane described in the Mesozoic section which also contains Paleozoic rocks. These terranes represent rocks that have a range of ages and lithologies, and have structural or tectonic characteristics that make them distinct from adjacent rocks. Some of these rocks may be displaced only tens of kilometers from their places of origin, while others may be displaced thousands of kilometers. The rocks in these terranes also have tectonic histories distinct from the rocks of the continental margin prior to the time of their accretion. The terranes were accreted by a combination of translational and compressional movement leading to large, steeply dipping fault zones and many imbricate slices of deformed rocks along the boundaries between these terranes and the continental margin.

- The Golconda terrane (GC, GChr) is a strongly deformed group of Upper Devonian through Middle Permian deep basinal sedimentary, distal shelf clastic, volcaniclastic, and volcanic rocks. The only basement known for the Golconda terrane is Mississippian to Permian slivers of ocean floor mafic and ultramafic rocks interleaved with the deep marine sedimentary and clastic rocks. It is structurally emplaced over coeval rocks of the Pennsylvanian to Triassic Siliciclastic overlap assemblage.

- The Upper Devonian Dutch Flat terrane (DF) is represented by the Harmony Formation, a feldspathic sandstone long thought to be Cambrian (Roberts, 1964). It is unconformably overlain by Pennsylvanian rocks of the Siliciclastic overlap assemblage providing an upper age limit. Its contacts with adjacent rock units are structural. It has a unique structural history and unique lithologic characteristics. Its origin and mode of emplacement remain unknown.

- The Paleozoic rocks of the Black Rock-Jackson terrane (BRJ) exposed in northwestern-most Nevada have stratigraphic and structural affinities with coeval rocks in the eastern Klamath Mountains. These rocks were accreted to other Mesozoic rocks in Nevada during Jurassic and (or) Cretaceous time.

Finally, Precambrian and Lower Cambrian clastic rocks conformably underlie the Carbonate shelf sequence in eastern and southern Nevada (€Zq, €Zqm, Zqs). They also form the stratigraphic base of the rocks of the Nolan belt. This sequence of Precambrian rocks is interpreted to represent the original rifted margin of western North America (Stewart, 1972), prior to the formation of the carbonate shelf. They rest unconformably over Proterozoic basement rocks (Yfi, Xm) that are only exposed in southernmost Nevada.

Three units are classified as Other rocks. A breccia unit of mixed breccias (br) not classifiable elsewhere identifies locally disrupted rocks. A metamorphic-igneous complex with Tertiary and Mesozoic metamorphic ages and Paleozoic to Archean protolith ages (TAgn) in Elko County is the only high-grade metamorphic rock in Nevada. Upper Paleozoic or Triassic ultramafic rocks including serpentine ( $\mathrm{kP} \mathbf{z p}$ ) are scattered in a few places around the State adjacent to major terrane boundaries. 


\section{Detailed Explanation of Geologic Units}

All of the descriptions below use information from the 1978 State map of Stewart and Carlson and from the accompanying text (Stewart, 1980), as well as material from each county map that is not always specifically referenced. Additional references are cited in the text. The county maps that were merged to create the Statewide geology layer consist of 16 different geologic maps that do not correspond exactly with the individual counties. References are commonly made in the text to the maps, not necessarily to the counties. The complete references for each county report are listed in the bibliography. The sixteen maps and the counties (or parts of counties) they represent are as follows:

\begin{tabular}{|lll|}
\hline Map name & County & Reference \\
\hline 1. Churchill & Churchill & Willden and Speed, 1974 \\
2. Clark & Clark & Longwell, Pampeyan, and others, 1965 \\
3. Elko & Elko & Coats, 1987 \\
4. Esmeralda & Esmeralda & Albers and Stewart, 1972 \\
5. Eureka & Eureka & Roberts, Montgomery, and Lehner, 1967 \\
6. Humboldt & Humboldt & Willden, 1964 \\
7. Lander & Lander & Stewart, McKee, and Stager, 1977 \\
8. Lincoln & Lincoln & Tschanz and Pampeyan, 1970 \\
9. LDC & Lyon, Douglas, and Carson & Moore, 1969 \\
10. Mineral & Mineral & Ross, 1961 \\
11. Nye North & Northern Nye & Kleinhampl and Ziony, 1985 \\
12. Nye South & Southern Nye & Cornwall, 1972 \\
13. Pershing & Pershing & Johnson, 1977 \\
14. Washoe North & Northern Washoe & Bonham and Papke, 1969 \\
15. Washoe South & Southern Washoe and Storey & Bonham and Papke, 1969 \\
16. White Pine & White Pine & Hose, Blake, and Smith, 1976 \\
\end{tabular}

\section{Quaternary Sediments and Rocks (Holocene and Pleistocene)}

Quaternary sediment and rock units reflect more inconsistency from county to county than rock units from most other age periods. Some counties differentiated older and younger alluvium and some did not, so two units were used but not always designated in each county, and their names are not consistent across county boundaries. Sand dunes, playas, and glacial moraines are also included as Quaternary units. Only one Quaternary volcanic unit, basalt flows, is designated. Quaternary and Pliocene sediments and sedimentary rocks include hot spring deposits, landslide deposits, older gravels, older alluvium, and volcaniclastic sediments. The youngest volcanic rocks in the State apart from the Quaternary basalt include late Tertiary or early Quaternary age basalt flows, andesite, rhyolite, and volcaniclastic sediments.

\section{Sediments and Sedimentary Rocks}

Qal Alluvium, undifferentiated-Unit is present in all counties. Some counties divided the alluvium into younger and older units, and some did not. For those that did not, or used other generalized terms for Quaternary rocks, the unit Qal has been used for the general undivided alluvium. Additionally, when polygons have been edited and changed to alluvium, Qal was used as the general value; hence it now is present in all counties

Qya Younger alluvium-Map unit is used in Churchill, Elko, Esmeralda, Eureka, Humboldt, Lander, and Lincoln Counties where geologic information suggests betterdefined younger versus older alluvium. It is mostly interchangeable with Oal, except that it implies some specifically younger Quaternary deposits

Qs Sand dunes-Unit is present in Clark, Humboldt, Lincoln, Churchill, Washoe, and Pershing Counties. There may be sand dunes in other counties that are not distinguished

Opl Playa, lake bed, and flood plain deposits-Map unit used in all counties for recent lake beds, playas, and flood plains. Polygons from the 1978 State map unit $\mathrm{Q} p$ were added where no playa was shown on the county maps

Og Glacial moraines-Sediments are present in southern Washoe, northern Nye, Esmeralda, Elko, Humboldt, White Pine, and Lander Counties in high mountain ranges 


\section{Volcanic Rocks}

$\mathrm{Qb}$

Basalt flows-Basalt flows, plugs, cinder cones, basaltic ash, scoria, and basaltic sediments. They are present in Nye, Esmeralda, and Churchill Counties

\section{Quaternary and Pliocene Sediments and Rocks}

\section{Sediments and Sedimentary Rocks}

QThs Hot spring travertine, sinter, and tufa (Holocene to Pliocene)—Calcareous and siliceous sinter and tufa deposits that are present in Washoe, Nye, Elko, Eureka, and Lander Counties

QTIs Landslide deposits, colluvium, and talus (Holocene to Pliocene)-Unit is mixed on the Washoe North map with basalt, tuff, diatomite, and tuffaceous sediments. It includes the units mapped as Qls from the 1978 State map. It is present in Churchill, Washoe, Nye, Esmeralda, Elko, Eureka, Humboldt, Lander, Lincoln, Mineral, and Pershing Counties

QTg Older gravels (Pleistocene and Pliocene)-Unit is used for pre-Lake Lahontan deposits, weakly consolidated gravel and sand, older gravels, pediment gravels, and gravel deposits. It includes all units designated as QToa on the 1978 State map. This unit is used in all counties

QToa Older alluvium and alluvial fan deposits (Pleistocene and Pliocene)—Unit consists mostly of older alluvium and alluvial fans. It also includes various stream deposits, gravel, fanglomerates, and older gravels. It is not very consistent in description from county to county. This is used in all counties except Clark

QTs Tuffaceous limestone, siltstone, sandstone, and conglomerate (Holocene to Pliocene)Present in Esmeralda, Elko, Mineral, Lyon, Douglas, Carson, and Eureka Counties and corresponds to unit QTs on the 1978 State map

\section{Volcanic Rocks}

QTb Basalt flows (Holocene to Pliocene)-Olivine basalt and basaltic and andesitic rocks. This unit is present in Clark, Elko, Mineral, Esmeralda, Humboldt, Lincoln, Lyon, Douglas, Carson, Nye, Washoe, and Lander Counties. It corresponds to the 1978 State map unit QTb
Andesite flows and breccias (Holocene to Pliocene)_Present in southern Washoe, Esmeralda, Lyon, Douglas, Carson, Mineral, and Lander Counties. It corresponds to unit QTa on the 1978 State map

Rhyolite dome (Holocene to Pliocene)_Unit is only present in southern Washoe and Mineral Counties. It corresponds to unit QTr on the 1978 State map

\section{Tertiary and Upper Cretaceous(?) Rocks}

Most Tertiary rocks in Nevada are volcanic. There are also a few lacustrine, fluvial, and tuffaceous sedimentary rocks that were deposited in Tertiary and possibly Upper Cretaceous basins scattered around the State. Tertiary intrusive rocks are distinguished by compositional and textural characteristics.

\section{Volcanic and Sedimentary Rocks}

Map unit names of the Tertiary volcanic and sedimentary rocks on this map follow closely the scheme used in Stewart and Carlson (1978) with a few additions and consolidations. There are three age groupings, from youngest to oldest, T3 (6-17 Ma), T2 (18-34 Ma), and T1 (35-43 Ma). There are five primary compositional and textural groupings for the volcanic and sedimentary rocks; sedimentary (Ts3), basaltic (Tb3), andesitic (Ta3), tuffaceous (Tt3), and rhyolitic (Tr3). The distinction between the Ts_ units and the Tt_units is that Ts_ represents sedimentary rocks that formed in a primary depositional environment (lake bed, fluvial, and so forth) with some amount of tuff or tuffaceous sedimentary rock as part of the sequences, while the $\mathrm{Tt}$ _ units are primarily volcanic in nature (welded or nonwelded tuffs) that may have interlayered tuffaceous sedimentary horizons. In addition to the scheme described above, there are a few Tertiary units (Tba, Tbg, and Ths) that cross time and compositional boundaries, and they are designated separately as described below.

Tba

Andesite and basalt flows (Miocene and Oligocene)_Generally poorly age constrained. This unit includes rocks originally mapped as the Pyramid sequence in Washoe County, the Mizpah Trachyte in Nye County, the Malpais Basalt, Rabbit Spring Formation, and Mira Basalt in Esmeralda County, and many other poorly dated unnamed basaltic and andesitic rocks around the State. It corresponds to unit Tba on the 1978 State map

Tbg Basalt, gravel, and tuffaceous sedimentary rocks (Miocene)_Basalt flows, cinder and lava cones, gravel, and tuffaceous sedimentary rocks mostly in Elko and some in Humboldt Counties. This unit includes the Banbury 
Formation (Stewart and Carlson, 1978) and the Big Island Formation in Elko County and other unnamed units. It corresponds to unit Tbg from the 1978 State map

Ths

Tuffaceous sedimentary rocks (middle Miocene to upper Oligocene)-Consists of the Horse Spring Formation in Clark and southern Nye Counties. This unit corresponds to unit Ths from the 1978 State map, and likely represents a composite of units Ts3 and Ts2. It is poorly known and may include rocks of other ages including Cretaceous

Ts3 Younger tuffaceous sedimentary rocks (Pliocene and Miocene)_-Tuffaceous and other young Tertiary sedimentary rocks. Most of these rocks are sedimentary with a strong volcanic component - a few are tuffaceous with a strong sedimentary component. This unit includes rocks originally mapped as the High Rock sequence in Washoe County; the Horse Camp Formation in northern Nye County; the Esmeralda Formation in Mineral and Esmeralda Counties; older lake beds in Lincoln County; the Belted Range Tuff; the Indian Trail Formation (now abandoned); Timber Mountain, Paintbrush, and Crater Flat Tuffs; Wahmonie and Salyer Formations in southern Nye County; the Siebert Tuff in Esmeralda County; the Muddy Creek Formation in Clark County; and the Thousand Creek and Virgin Valley "beds" in Humboldt County; and other unnamed units. It corresponds to units Ts 3 and Tts from the 1978 State map. It is present in all counties

Tb3 Basalt (Miocene)_Basalt flows, plugs and dikes, some olivine basalt, and andesite and latitic rocks. This unit corresponds with unit Tb on the 1978 State map. It is present on the Washoe North, Washoe South, Lincoln, Clark, Elko, Eureka, Humboldt, Nye South, and Lander County maps

Ta3 Younger andesite and intermediate flows and breccias (Miocene)-Includes some rocks mapped as the Kate Peak and Alta Formations on the Washoe South map; Wahmonie and Salyer Formations on the Nye South map; Gilbert Andesite on the Esmeralda map; pyroxene, hornblende phenoandesite, and phenodacite on the Elko map; and other unnamed units. It corresponds to the unit Ta3 on the 1978 State map. It is present everywhere except Eureka and White Pine Counties

Tt3 Younger silicic ash flow tuffs (Miocene)-Includes units mapped as the High Rock sequence on the Washoe North map; the Timber
Mountain, Paintbrush, Crater Flat, and Belted Range Tuffs, and Indian Trail Formation (now abandoned) on the Nye South map; the Thirsty Canyon Tuff on the Nye South and Esmeralda maps; and other unnamed units. Locally it includes tuffaceous sedimentary rocks interstratified with tuffs. It is present in the northernmost part and southernmost parts of the State, and is not exposed in the central region. It corresponds to unit Tt3 on the 1978 State map, although a few rocks also mapped as Trt on the 1978 State map also are included. It is present in Clark, Churchill, Washoe, Nye, Lincoln, Lyon, Douglas, Carson, Esmeralda, Elko, Humboldt, Pershing, and Mineral Counties

Tr3 Younger rhyolitic flows and shallow intrusive rocks (Miocene)-Rhyolitic flows, domes, plugs, breccias, quartz latite, rhyodacite, quartz porphyry dikes, and other shallow intrusive rocks. This unit includes rocks mapped as the Cañon Rhyolite on the Washoe North map, the Jarbidge Rhyolite and phenorhyolitic and phenodacitic flows and domes on the Elko County map, and other unnamed units. It has a distribution similar to Tt3, with exposures in the northern and southern parts of the State, but only crops out in a few places in the central region. It corresponds to unit $\operatorname{Tr} 3$ on the 1978 State map, and also includes a few rocks mapped as Trt on the 1978 State map. This unit is exposed in every county except White Pine

Ts2 Older tuffaceous sedimentary rocks (lower Miocene and Oligocene)_Locally includes minor amounts of tuff. It includes rocks mapped as the Titus Canyon Formation on the Nye South map, the Gilmore Gulch Formation on the Nye North map, lacustrine limestone in Lincoln County, and other unnamed units. This unit corresponds to unit Ts2 on the 1978 State map. It is present in Nye, Lincoln, Elko, and Lander Counties

Tb2 Basalt, tuff, and breccia (lower Miocene and Oligocene)_Basalt flows, basaltic tuff, tuff breccia, and andesitic rocks in Elko and Humboldt Counties. These rocks correspond to unit Tob on the 1978 State map

Intermediate andesite and intermediate flows and breccias (lower Miocene and Oligocene)Andesite flows and breccias and other related rocks of intermediate composition such as dacite, rhyodacite, quartz latite, and biotite-hornblende porphyries. This unit 
includes units mapped as the South Willow Formation on the Washoe North map, the Milltown Andesite on the Nye South and Esmeralda County maps, the Mizpah Trachyte on the Nye North map, and other units. It corresponds to unit Ta2 on the 1978 State map. It crops out in all counties except Clark, Eureka, Lyon, Douglas, and Carson

Intermediate silicic ash flow tuff (lower Miocene and Oligocene)—Welded and nonwelded silicic ash flow tuffs. Aside from alluvium, this unit covers more of Nevada than any other rock, with over 4,000 polygons representing it on this map. It is principally exposed in the central regions of the State. It locally includes thin units of air fall tuff and sedimentary rocks. It includes rocks mapped on the Washoe South, Lyon, Douglas, and Carson Counties maps as the Hartford Hill Rhyolite Tuff (now abandoned); on the Nye South map as the tuff of White Blotch Spring, the tuffs of Antelope Springs, and the tuff of Monotony Valley; in Lander County it is mapped as the Bates Mountain Tuff, Caetano Tuff, Edwards Creek Tuff, New Pass Tuff, tuff of Hall Creek, and the tuff of McCoy Mine; in Lander and Pershing Counties it is the Fish Creek Mountains Tuff; on both of the Nye County maps it is the Fraction Tuff; it also includes the Pancake Summit Tuff, Northumberland Tuff, Shingle Pass Tuff, some outcrops of Darrough Felsite shown to be Tertiary (other outcrops have been shown to be Mesozoic or Paleozoic), tuffs of Moores station, tuffs of Peavine Canyon, tuffs of the Pancake caldera complex, the Stone Cabin Formation, tuff of Saulsbury Wash, tuff of Kiln Canyon, the Tonopah Formation, tuffs of Hannapah, tuff of Bald Mountain, the Needles Range Formation, and the Calloway Well Formation on the Nye North map; in Esmeralda County it is the Kendall Tuff and latite; and in northern Nye and Lander Counties it is the Toiyabe Quartz Latite (now abandoned), and other unnamed units. It corresponds to unit Tt2 on the 1978 State map. It crops out in every county except Clark

Intermediate rhyolitic flows and shallow intrusive rocks (lower Miocene and Oligocene)Includes rocks mapped as the rhyolite of Big Sand Springs Valley on the Nye North map, the Sandstorm Formation in Esmeralda County, rhyolite flow domes in the Sheep
Creek Range in Lander County, and other units. It corresponds to unit Tr2 on the 1978 State map. It is present in Nye, Lincoln, Churchill, Esmeralda, Eureka, Mineral, Elko, Humboldt, and Lander Counties

TKs1 Conglomerate, lacustrine, and tuffaceous sedimentary rocks (lower Oligocene to Upper Cretaceous(?))_Includes the Sheep Pass Formation and equivalents in northern Nye, Lincoln, Elko, Eureka, Lander, and White Pine Counties. In most places the Sheep Pass Formation is Paleocene or Eocene (Fouch, Hanley, and Forester, 1979), although rocks from the Carlin-Piñon Range area that contain Late Cretaceous fossils have been included in the Sheep Pass Formation (Smith and Ketner, 1976, 1978). It corresponds to unit Ts 1 on the 1978 State map

Ta1 Older andesite and intermediate flows and breccias (lower Oligocene to middle Eocene)—Unit includes andesite or dacite flows, flow breccias, and hypabyssal rocks in Lander County, andesitic to latitic flows, pyroclastic rocks, and phenoandesitic and phenolatitic flows in Elko County, and other undifferentiated volcanic rocks in other counties. Present in Humboldt, northern Nye, Churchill, Elko, Eureka, Lander, and White Pine Counties. It corresponds to the 1978 State map unit Ta1

Tt1 Older silicic ash flow tuffs (lower Oligocene to middle Eocene)—Welded and nonwelded silicic ash flow tuffs, locally includes thin units of air fall tuff and sedimentary rock. This unit corresponds with the 1978 State map unit Tt1. These rocks are present in northern Nye, Elko, Eureka, and White Pine Counties

Tr1 Older rhyolitic flows and shallow intrusive rocks (lower Oligocene to middle Eocene) Includes rhyolitic lava of Portuguese Mountain in northern Nye County, rhyodacite in Elko Hills in Elko County, and other unnamed units. The rhyodacite in Elko Hills was shown on the 1978 State map as unit $\operatorname{Tr} 1$, and on the Elko County map as the Jurassic Frenchie Creek Rhyolite. It was subsequently renamed the Rhyodacite of Elko Mountain (Ketner, 1990) when the late Eocene radiometric age of approximately 39.5 Ma was obtained. It corresponds to unit $\operatorname{Tr} 1$ on the 1978 State map. This unit is present in northern Nye, Elko, Eureka, and White Pine Counties 


\section{Intrusive Rocks}

The groupings for Tertiary intrusive rocks are both compositional and textural. Two phaneritic compositions, mafic (Tmi) and felsic (Tfi), and one aphanitic composition, rhyolitic (Tri), are shown. More detail on definitions of intrusive rocks is provided under Mesozoic Intrusive Rocks. A companion publication to this one with more detailed, updated, and accurate intrusive rock assignments should be consulted for northeastern Nevada (du Bray and Crafford, 2007).

\section{Tmi Mafic phaneritic intrusive rocks (Miocene to} middle Eocene)—-Tertiary mafic intrusive rocks are widely scattered across Nevada north of Clark County. They include rocks mapped as dacite and rhyodacite, diorite, quartz latite, and numerous undivided intrusive rocks on the county maps

Felsic phaneritic intrusive rocks (Miocene to Eocene)-Tertiary felsic intrusive rocks are widely scattered in every county across the State. They are generally described as granitic rocks, granodiorite, monzonite, quartz monzonite, alaskitic granite, quartz diorite, dacite, and rhyodacite in the places where they are shown separately on county maps

\section{Rhyolitic intrusive rocks with aphanitic} groundmass (Miocene to middle Eocene)-Tertiary rhyolitic intrusive rocks also are present in every county of Nevada. They include many rocks mapped as rhyolite or rhyolite porphyry, rhyolite intrusive rocks, rhyolite plugs or flows, microgranite dikes, and many other undifferentiated intrusive rocks

\section{Miocene(?) to Jurassic(?) Intrusive Rocks}

These rocks are poorly constrained in age, and are shown only as mafic or felsic phaneritic intrusive rocks. They could range in age from Miocene to Jurassic. See the description below under Mesozoic intrusions for more details about the unit definitions.

TJmi Mafic phaneritic intrusive rocks-Poorly dated mafic intrusions are concentrated in two regions of Nevada, northwestern and westcentral to southwestern parts of the State. They crop out in northern Nye, Mineral, Esmeralda, Eureka, Humboldt, and Lander Counties, and include rocks described on the county maps as dioritic to andesitic rocks, diorite and related rocks, and granodiorite felsic intrusions described as granitic rocks,

$\mathrm{Kfi}$ granite porphyry, granodiorite, quartz monzonite, and many undivided plutonic rocks are included here. They crop out in every county except Elko and northern Washoe

\section{Mesozoic Intrusive and Volcanic Rocks}

A few Triassic, and numerous Jurassic and Cretaceous plutons of various compositions are scattered across the State, with a concentration along the Sierra Nevada Mountains associated with Mesozoic arcs. Mesozoic volcanic rocks ranging in composition from felsic to mafic are spread across the central part of the State. Their tectonic settings and origins are not well understood, but they are likely related to Triassic and Jurassic arc complexes, and possibly also to accreted terranes.

\section{Intrusive Rocks}

Intrusive rocks include many Jurassic and Cretaceous plutons ranging in composition from diorite to granitepredominantly granodiorite and quartz monzonite. The classification scheme for the intrusive rocks is a designation by age (Triassic, Jurassic, or Cretaceous) and composition, and is much generalized, taken primarily from designations given in Stewart and Carlson (1978). Compositionally, rocks are designated as either felsic (fi) or mafic ( $m i$ ), except for the Jurassic gabbro complex (Jgb). Where composition is poorly known, rocks are simply designated as $(i)$. A more comprehensive analysis of intrusive rock compositions and textures, with updated values using actual modal data for northeastern Nevada, is presented in a separate publication (du Bray and Crafford, 2007).

Kmi Mafic phaneritic intrusive rocks (Cretaceous) Rocks mapped as Cretaceous dioritic rocks only crop out in northern Nye County in the San Antonio Mountains, and in a belt in far northwestern Nye County from the Monte Cristo Mountains east to the Shoshone Mountains

Felsic phaneritic intrusive rocks (Cretaceous) Granodiorite, granite, and related rocks make up the largest group of granitic intrusions exposed in Nevada. They are present in every county, and are especially abundant in west-central Nevada in an arcuate belt along the border with California extending north and eastward towards Idaho

Dikes (Cretaceous) — These dike rocks of unknown composition are mapped in the Shawave Mountains in Pershing County, the Osgood Mountains and Edna Mountain in Humboldt County, and just outside of Eureka

Gabbro complex, anorthosite, and albitite (Early Cretaceous to Middle Jurassic)—A large complex of gabbroic rocks forms a series 
of related intrusions in the northern parts of the Stillwater Range and Clan Alpine Mountains of Churchill County and in the West Humboldt Range of Pershing County (Willden and Speed, 1974). It also may extend into the Trinity Range and Shawave Mountains in western Churchill County (Greene, Stewart, and others, 1991). The complex contains highly differentiated facies near the periphery of the body and more homogeneous gabbro in the interior. Layered rocks near the margins include picrite, olivine gabbro, hornblende gabbro, and anorthosite. The homogeneous rocks consist largely of feldspathic hornblende gabbro and analcite gabbro. The complex is interpreted to be part of a continental Jurassic volcanic arc that is the northern continuation of a Jurassic continental margin arc that extended from the Sonora Desert region in the south to northern California in the north (Dilek and Moores, 1995; Zientek, Sidder, and Zierenberg, 2004). Biotites from several places in the gabbro have been dated by K/Ar and range from 140 to $170 \mathrm{Ma}$

Jmi Older mafic phaneritic intrusive rocks (Jurassic)—Unit includes diorite in northern Elko County, diorite to granodiorite in the Toquima Range of northern Nye County, and dioritic rocks in western Churchill County

\section{Older felsic phaneritic intrusive rocks} (Jurassic)-Concentrated in two areas of the State; common in the west-central part of the State along the California border in Mineral, Esmeralda, Lyon, Douglas, and Carson Counties. There is another more widely scattered group in eastern and central Nevada in Elko, Eureka, and White Pine Counties. Scattered occurrences also are present in Humboldt, Churchill, Lander, and Pershing Counties. Compositions are mainly granitic, granodiorite, and quartz monzonite
Phaneritic intrusive rocks (Jurassic)—Quartz monzonite to Quartz diorite intrusions crop out in west-central Nevada in the Singatse Range in Lyon County, the Gillis Range in Mineral County, the Toquima Range on the Nye/Lander County boundary, in northern Nevada at Buffalo Mountain in Humboldt County, and in the East Range in Pershing County

Felsic phaneritic intrusive rocks (Triassic)Intrusive rocks crop out in the East Range and Humboldt Range in Pershing County associated with the Koipato Group volcanic rocks ( $\mathrm{k} k \mathrm{k}$ ). They intrude upper Paleozoic rocks of the Golconda terrane (GC) and rocks of the Koipato Group. Limited older evidence suggests that these rocks may be Triassic (Silberling and Wallace, 1967; Wallace, Silberling, and others, 1969; Wallace, Tatlock, and Silberling, 1960; Wallace, Tatlock, and others, 1969), but new data (du Bray and Crafford, 2007) suggests that most of the intrusive rocks mapped as Triassic in the East and Humboldt Ranges are Cretaceous or younger. In northern Esmeralda County between the Royston Hills and the Monte Cristo Range small exposures of Upper Triassic plutons are inferred to relate to the Lee Vining intrusive epoch in eastern California (Stewart, 1980). These rocks also intrude into the Golconda terrane $(\mathrm{GC})$

\section{Volcanic Rocks}

Triassic volcanic rocks are present only in west-central Nevada. They include the Koipato Group ( $\mathrm{k} k \mathrm{k}$ ) volcanic and sedimentary rocks which unconformably overlie the Golconda terrane in a large area of eastern Pershing County and mafic volcanic rocks ( $\mathrm{k} v \mathrm{~m}$ ) in the Humboldt and East Ranges in Pershing County that are present as flows interbedded with Triassic carbonate rocks. Jurassic felsic volcanic rocks (Jvr) are isolated in the Cortez Mountains and Dry Hills around Crescent Valley in northern Eureka County near Carlin. Jurassic basaltic rocks (Jvb) are present in Churchill County in the Stillwater Range associated with Jurassic gabbro (Jgb) and quartzose sandstone (Jcg). In far western Nevada around Reno, a sequence of Triassic(?) and Jurassic(?) metamorphosed volcanic rocks ( $\mathrm{J} \mathrm{k} \mathrm{v}$ ) is dissimilar to other Mesozoic rocks in the area, and may represent a distinct terrane.

Jvb Flows, basaltic tuffs, and lapilli tuffs (Middle(?) Jurassic)—Layered tuff, lapilli tuff, bedded agglomerate, tuff breccia, autobreccia, and lava, chiefly basaltic. Jurassic mafic volcanic rocks are present in the Stillwater Range in Churchill County, with smaller exposures in the West Humboldt Range. In the Stillwater Range they are intimately associated with gabbroic intrusive rocks (Jgb). They conformably overlie and locally are interbedded with quartz arenite (Jcg). The lavas are homogeneous basalts that contain microphenocrysts of labradorite, diopsidic augite, and talc-hematite after olivine. The groundmass is plagioclase-clinopyroxeneiron oxide (Willden and Speed, 1974). They are believed to be Middle Jurassic because 
they are thought to be comagmatic with the gabbro (Jgb). This unit is included within the 1978 State map unit Jgb

Jvr Rhyolite flows, tuffs, and volcaniclastic rocks (Upper Jurassic)—Rhyolite flows, felsic ash-flow tuffs and volcaniclastic rocks of the Pony Trail Group (Muffler, 1964) are the only recognized Jurassic felsic volcanic rocks in Nevada, cropping out in northern Eureka County in the Cortez Mountains area. They are dated as Jurassic by a radiometric date from 1972 (Smith and Ketner, 1976). The Pony Trail Group is made up of (in ascending order) the volcaniclastic Big Pole Formation; a silicic ash-flow tuff unit, the Sod House Tuff; and the boldly outcropping Frenchie Creek Rhyolite made of tuffs, volcaniclastic horizons and flows (Smith and Ketner, 1976). While some of these rocks likely are Jurassic, rocks mapped on the Elko County map as the Frenchie Creek Rhyolite exposed in the Elko Hills northeast of Elko have been shown to be Tertiary and renamed (Ketner, 1990) so it is possible that parts of the section included in the Frenchie Creek Rhyolite are not Jurassic. This unit corresponds to unit JV on the 1978 State map

J RV Metavolcanic rocks (Jurassic(?) and Triassic(?))—Metamorphosed (generally greenschist-facies) andesite and dacite flows and breccias, flow-banded rhyolite and rhyodacite, welded tuff, local hypabyssal intrusive rocks, and minor amounts of volcaniclastic sandstone and conglomerate (Greene, Stewart, and others, 1991). This unit includes the Peavine sequence in Washoe County, and other unnamed metasedimentary and metavolcanic rocks in Lyon, Douglas, Carson, and Churchill Counties. These rocks are considered distinct from the other metavolcanic and metasedimentary rocks in adjacent Mesozoic terranes. They are included in unit J ksv on the 1978 State map

Kvm Mafic flows and volcanic breccias (lower Upper Triassic to lower Middle Triassic)Amygdaloidal, nonporphyritic, massive flows and breccia, tuff, and tuffaceous argillite are interbedded with limestones in the Smelser Pass Member of the Augusta Mountain Formation in the Star Peak Group Triassic sedimentary rocks ( $\mathrm{kc}$ ) in Pershing County (Nichols and Silberling, 1977b). They are well dated by abundant fossils from the surrounding rocks and range from lower Upper Triassic (Carnian) to lower Middle Triassic (Anisian) (Silberling and Wallace, 1969). They are not divided out on the 1978 State map from the surrounding Triassic carbonate unit $\mathrm{kc}$

K kv Andesite, rhyolite, tuff, and volcaniclastic rocks (Middle and Lower Triassic)_Andesite, rhyolite, tuff, and generally siliceous volcaniclastic rocks make up the Koipato Group, which lies unconformably below the Humboldt assemblage. The Koipato Group consists of altered porphyritic andesite flows and flow breccia of the Limerick Greenstone, altered felsite and coarsegrained tuffaceous sedimentary rocks of the Rochester Rhyolite, and quartz-rich ash-flow tuff and tuffaceous sedimentary rocks of the Weaver Rhyolite. It is present in Churchill, Humboldt, Lander, and mostly Pershing Counties where it unconformably overlies deformed rocks of the Golconda terrane (GC). The upper part of the Koipato contains late Early Triassic (Spathian) fossils (Silberling, 1973; Wallace, Tatlock, and others, 1969). It is depositionally overlain by the Star Peak Group ( $\mathrm{kc}$ ), a sequence of carbonate platform deposits at the base of the Humboldt assemblage. Radiometric dates from the 1970s (McKee and Burke, 1972) suggest a Middle to Early Triassic age

\section{Mesozoic Terranes, Sedimentary Rocks, and Assemblages}

Ten different groupings of Mesozoic terranes, sedimentary rocks, and assemblages are recognized in the State. Mesozoic sedimentary rocks are difficult to classify because of the diversity of their structural histories, depositional settings, and basements coupled with our incomplete knowledge of their relations to one another. Generally, they can be grouped into two categories - those sequences that are deposited on a known basement, and those sequences that are strongly disrupted and their basement is either unknown or intimately deformed along with them as part of a larger terrane. In places where the Mesozoic rocks have a complex deformation history, they are not grouped by formation, but rather they are grouped as either terranes or assemblages. Terranes are used in the classic sense for fault-bounded geologic entities of regional extent, each characterized by a geologic history that is different from the histories of contiguous terranes (Jones, Howell, and others, 1983). Assemblage, an informal term, is used for a group of related rock units within a terrane or for a unit (or units) that 
has a known basement, but is geographically isolated and lithologically and (or) structurally distinct from other coeval rocks. This can result in traditional formation names being used across assemblages, but it provides a clearer picture of the tectonic groupings of the rocks. This, in turn, provides the framework for understanding the overall tectonic evolution of these rocks and how their complex relations to one another have evolved over time. The groupings used here generally follow earlier terrane maps and discussions (Silberling, 1991; Silberling, Jones, and others, 1987; Silberling, Jones, and others, 1992) with a few modifications.

The disrupted rocks with unknown basement include those in:

- the Walker Lake terrane composed of Mesozoic carbonate, siliclastic, volcanic, and volcaniclastic rocks in Lyon, Mineral, and western Nye Counties which is broken into three distinct assemblages (WPN, WPL, WLB),

- the Black Rock-Jackson terrane (BRJ) that includes Mississippian to Middle Jurassic carbonate, clastic, and volcaniclastic rocks,

- the Sand Springs terrane (SAS) which extends from the northwestern corner of Nye County northwest into Washoe County, consisting mostly of volcanic rocks of Late Triassic and Early Jurassic age,

- the Quartz Mountain terrane (QM), a structurally disrupted unit of unknown Mesozoic or Paleozoic age in Churchill and northern Nye Counties, which is distinguished lithologically by the association of orthoquartzite with feldspathic sandstone and (or) volcanic rocks, and

- the Jungo terrane (JO) in west central and northwestern Nevada consisting of Triassic to Lower Jurassic fine-grained terrigenous clastic rocks.

All of the rocks of these terranes have experienced varying degrees of deformation and metamorphism, and have complex tectonic histories.

The rocks that are deposited on a known basement include:

- Localized clastic rocks (TKcg, Kcg, Jcg) scattered in several places across the State,

- the Gold Range assemblage (J kgor) in Mineral and western Nye Counties,

- the Humboldt assemblage ( $\mathrm{kc}, \mathrm{J} \mathrm{ks}$ ) in a large area of Pershing, Churchill, and Lander Counties,

- the Candelaria Formation ( $\mathrm{k} \mathrm{cl}$ ) of the Siliciclastic overlap assemblage best exposed south of Mina, and

- the Cratonal sequence ( $\mathrm{kmt}, \mathrm{J}$ kch, Jas) in the eastern and southern parts of the State.

\section{Terranes}

\section{Walker Lake Terrane}

The Walker Lake terrane is divided into three assemblages or allochthons, not two subterranes as in earlier discussions (Silberling, oral commun., 2006). The three assemblages, Pine Nut (WPN), Pamlico-Lodi (WPL), and Luning-Berlin (WLB), have similar but not identical stratigraphic characteristics, and the Pine Nut assemblage has a distinct structural history. The Pamlico-Lodi and LuningBerlin assemblages have different degrees of similar deformation, and different stratigraphic sequences in the oldest and youngest rocks. All three assemblages are structurally bounded from one another. Together, they form a southeastvergent accretionary complex of Triassic volcanogenic rocks, in part, interfingering with and overlain by an extensive Upper Triassic to Lower Jurassic carbonate platform assemblage that has intercalations of terrigenous and volcaniclastic rocks, and grades upward into nonmarine terrigenous clastic and volcanogenic rocks (Silberling, 1991). The upper Paleozoic andesitic rocks originally included here (Pablo Formation) are now reassigned to the Golconda terrane, and are overlain by the distinct Gold Range assemblage (Jkgor). The Sand Springs assemblage, originally included in the Paradise terrane (Silberling, Jones, and others, 1987), also has been designated as a separate terrane and is not included here. The oldest Mesozoic rocks in this terrane containing abundant quartzose and continentally derived clastic materials are latest Triassic in age; the youngest stratified rocks are partly synorogenic deposits of late Early Jurassic and possibly younger age (Silberling, 1984; Whitebread and John, 1992). Rocks in the Pamlico-Lodi and Luning-Berlin assemblages are present in numerous thrust nappes representing several major juxtaposed allochthons (Oldow, 1984a; Oldow, Satterfield, and Silberling, 1993; Silberling and John, 1989; Silberling, Jones, and others, 1992; Speed, Silberling, and others, 1989).

WPN Nut assemblage-Volcanogenic, carbonate,
and clastic rocks (Middle(?) Jurassic
to Middle Triassic)_This assemblage is
composed of Upper Triassic basinal-marine
volcanic and carbonate rocks overlain
by Lower Jurassic fine-grained, marine
siliciclastic and tuffaceous sedimentary
rocks, and by partly nonmarine sandstone,
coarse clastic rocks, and volcanic rocks of
late Early Jurassic and possibly younger
age. This assemblage has stratigraphic
similarities to the Luning-Berlin and
Pamlico-Lodi assemblages, but shares
only part of their late Mesozoic structural
history, and is separated from them by the
linear trace of the northwesterly trending
Pine Nut fault (Oldow, 1984a; Silberling,
Jones, and others, 1992). Structurally, the
rocks are involved in only a single phase of


tight to isoclinal folds with north-northwest striking axial planes, and no major internal thrust faults are known (Oldow, 1984a). The Pine Nut assemblage crops out in southern Washoe, Lyon, Douglas, Carson, and Mineral Counties, and includes rocks originally mapped as the Excelsior Formation, the Peavine sequence, and other metasedimentary and metavolcanic rocks

WPL Pamlico-Lodi assemblage-Carbonate and volcanogenic rocks (Middle(?) Jurassic to Middle Triassic)—The PamlicoLodi assemblage differs stratigraphically from the Luning-Berlin assemblage in that the Triassic carbonate sequences are interstratified with volcanic and volcanogenic rocks, not continentally derived epiclastic chert, conglomerate, sandstone, and argillite (Oldow, Satterfield, and Silberling, 1993; Silberling and John, 1989). The uppermost part of the sequence is a regionally extensive carbonate shelf like the Luning-Berlin assemblage. This is conformably overlain by quartz arenite and poorly sorted coarse clastic rocks faunally dated as Early Jurassic that grade upward into volcanogenic sedimentary and volcanic rocks (Oldow, 1984a; Oldow and Bartel, 1987). The Pamlico-Lodi assemblage has a polyphase folding history similar to the Luning-Berlin assemblage that was caused by northwest-southeast directed thrusting that displaced the rocks tens of kilometers toward the southeast (Oldow, 1984a). Compared with the Luning-Berlin assemblage to the east, however, rocks of the Pamlico-Lodi assemblage manifest much more shortening from this first deformation of southeast-directed tectonic transport (Speed, Silberling, and others, 1989). This assemblage is exposed in Churchill, Mineral, and northern Nye Counties. It includes rocks mapped as Dunlap, Excelsior, Gabbs, Sunrise, and Luning Formations

WLB Luning-Berlin assemblage-Carbonate and terrigenous clastic rocks (Middle(?) Jurassic to Middle Triassic)—Assemblage is underlain by the regionally extensive Luning thrust and lies structurally below the Pamlico-Lodi assemblage (WPL) (Oldow, 1984a). The Upper Triassic continental shelf sequence part of WLB consists of platform carbonate rocks and shallow-marine to deltaic-clastic rocks. Minor amounts of volcanogenic rocks are interbedded with terrigenous clastic rocks near the western margin of the assemblage (Oldow, 1984a). These are conformably overlain by Lower (Pliensbachian) to Middle Jurassic quartz arenite and coarse clastic rocks which grade upward into volcanogenic rocks (Oldow, 1984a; Oldow and Bartel, 1987).

Rocks of the Luning-Berlin assemblage are involved in a complex deformational history involving first northwest-southeast thrusting, followed by second folds with northnorthwest to west-northwest axial planes (Oldow, 1984a). The folding is constrained between Middle Jurassic and Late Cretaceous (90 Ma) (Oldow, 1984a). Rocks that have been assigned to the Dunlap, Gabbs, Sunrise, Luning, and Grantsville Formations are included in this assemblage (Silberling, 1984; Whitebread and John, 1992)

\section{Black Rock-Jackson Terrane}

\section{BRJ Basinal, island arc, carbonate, and} volcanogenic rocks (Middle Jurassic to Mississippian)-This composite terrane includes Mississippian to Middle Triassic oceanic-basin and island-arc rocks in isolated exposures in northwesternmost Nevada originally assigned to the Black Rock terrane, and Upper Triassic to Middle Jurassic volcanogenic and volcanic rocks of the Jackson terrane in the same region. These rocks crop out in southern Washoe, Humboldt, and Pershing Counties. Parts of the Black Rock terrane can be interpreted as the base of the Jackson terrane, but they are generally structurally juxtaposed throughout the region (Jones, 1990; Russell, 1984; Silberling, Jones, and others, 1987; Wyld, 1990). Rocks of this terrane have affinities with correlative rocks in the Eastern Klamath and Northern Sierra terranes in California (Silberling, Jones, and others, 1992)

\section{Sand Springs Terrane}

\section{SAS}

\section{Basinal volcanogenic rocks and carbonate} turbidites (Lower Jurassic and Upper Triassic)-The Sand Springs terrane is a highly deformed, thick, mainly basinal volcanogenic assemblage of rocks at least partly of early Mesozoic age and possibly having affinities with rocks of the Black Rock-Jackson terrane (Silberling, 1991). The presumably oldest Mesozoic rocks are volcanogenic and carbonate turbidites 
interbedded with mudstone which grade upward into interbedded basinal carbonates and volcanogenic rocks containing Late Triassic faunas (Oldow, 1984a). Elsewhere, interbedded carbonate, volcanic, and volcanogenic rocks are assigned an Early to Middle Jurassic age and represent relatively shallow-marine to subaerial deposition (Oldow, 1984a). Although structural relations in the Sand Springs terrane are locally complicated by later Cenozoic deformation, the rocks appear to have been involved in major northwest-southeast shortening between the Early Jurassic and Late Cretaceous (80 Ma) (Oldow, 1984a). The rocks of the Sand Springs terrane crop out in southern Washoe, Pershing, Churchill, Mineral, and northern Nye Counties

\section{Quartz Mountain Terrane}

\section{QM Orthoquartzite, feldspathic sandstone, and volcan-} ic rocks (Mesozoic or Paleozoic, possibly Jurassic)—The Quartz Mountain terrane, of unknown Mesozoic or Paleozoic age, is distinguished lithologically by the association of orthoquartzite with feldspathic sandstone and (or) volcanic rocks (Silberling, oral commun., 2006). Other rock types include metapelite, dolomite, and locally derived coarse clastic rocks (Silberling and John, 1989). This structurally disrupted mass is intricately intruded by and structurally brecciated with igneous rocks in the Lodi Hills. The structures that bound the intrusive rocks are thought to postdate the fault or faults on which the sedimentary rocks of the Quartz Mountain terrane were originally emplaced (Silberling and John, 1989). Exposures in the La Plata quadrangle mapped as the Mountain Well sequence, have here been assigned to the Quartz Mountain terrane (John and Silberling, 1994). These rocks are exposed in Churchill and northern Nye Counties

\section{Jungo Terrane}

JO Turbiditic, fine-grained, terrigenous clastic rocks (Middle Jurassic to Upper Triassic)—The Jungo terrane, also called the Lovelock assemblage or Fencemaker allochthon (Oldow, Satterfield, and Silberling, 1993), consists of complexly deformed, thick basinal, turbiditic, fine-grained, terrigenous clastic rocks, mainly Norian, but also as young as Pliensbachian (Late Triassic and
Early Jurassic) age. It crops out in southern Washoe, Churchill, Humboldt, and Pershing Counties. These rocks represent the basinal facies component of the Auld Lang Syne Group (Burke and Silberling, 1973; Lupe and Silberling, 1985). The Jungo terrane has no known basement and is structurally detached from coeval shelf facies (Silberling, Jones, and others, 1992). It is locally overlain unconformably by Middle or Upper Jurassic peritidal sedimentary rocks (Jcg) intruded by a gabbroic igneous assemblage (Silberling, 1991). Rocks included with the Jungo terrane were originally mapped as the Grass Valley Formation of the Auld Lang Syne Group in Humboldt and Pershing Counties; some rocks were mapped as the Happy Creek Volcanic "series" (now the Happy Creek Volcanic Complex) in Humboldt County, the Nightingale sequence in southern Washoe County, the Osobb Formation of the Auld Lang Syne Group in Churchill County, and the Winnemucca and Raspberry Formations of the Auld Lang Syne Group (Compton, 1960) in the Santa Rosa Range in Humboldt County

\section{Sedimentary Rocks and Assemblages}

\section{Localized Clastic Rocks}

Scattered occurrences of Mesozoic conglomeratic rocks and sandstone (TKcg, Kcg, Jcg) are present in several places in Nevada. They lie unconformably over older, deformed rocks thus serving as important age constraints on underlying rocks and deformation. Their isolated occurrences are significant indicators of local and regional tectonic events, but their ages are generally poorly constrained.

TKcg Conglomerate and clastic rocks (Tertiary(?) and Cretaceous(?)) - These conglomeratic, tuffaceous, and other clastic rocks are not well enough constrained to be assigned either a Tertiary (unit TKs1) or Cretaceous (unit Kcg) age, so they are grouped as TKcg. Like the Cretaceous clastic unit Kcg, these rocks sit unconformably on many different age rocks. Included in this unit are units previously mapped as "Older clastic rocks" in Lincoln County; conglomerate, clastic rocks, and tuff in northern Nye County; the Gale Hills Formation in Clark County; and the Pansy Lee Conglomerate in the Krum Hills and Jackson Mountains in Humboldt County

Kcg Siltstone, shale, conglomerate, and limestone (Cretaceous)_-Includes detrital deposits of 
continental origin, and locally derived fluvial and lacustrine clastic rocks, some interbedded with siltstone and freshwater limestone. Outcrops are concentrated in three separate areas of the State. In each place, limited biostratigraphic data indicate these rocks are Cretaceous. The King Lear Formation in the Jackson Mountains in Humboldt County lies unconformably on Triassic and older rocks of the Black Rock-Jackson terrane. The Newark Canyon Formation crops out mostly in Eureka and White Pine Counties but extends into Elko and Nye Counties as well, and rests unconformably on Ordovician to Permian rocks. In places it is difficult to distinguish Upper Devonian, Pennsylvanian, and Permian clastic rocks also derived from the nearby underlying bedrock from the Newark Canyon Formation, and some confusion still exists. The Willow Tank Formation in Clark County lies unconformably on Jurassic rocks and is overlain by what was mapped as the Baseline Sandstone and Overton Fanglomerate (now referred to as the Overton Conglomerate Member of the Baseline Sandstone), all of Cretaceous age (Middle and Lower Jurassic)—The Boyer Ranch Formation in the Clan Alpine and Stillwater Ranges in Pershing and Churchill Counties consists of a basal conglomerate overlain by partly silicified limestone that is overlain by quartz sandstone. In places it rests unconformably over Upper Triassic or younger rocks (Speed and Jones, 1969) of the Jungo terrane ( $\mathrm{JO}$ ), constraining its maximum age, and elsewhere it is faulted over Late Triassic and Early Jurassic rocks (Speed and Jones, 1969). The occurrence of conglomerate-bearing clasts of underlying units at the base of the formation supports the interpretation of unconformable basal contacts even though the unit is strongly folded (Speed and Jones, 1969). It is overlain by volcanic rocks that are comagmatic with the adjacent Middle Jurassic gabbro. In the Pamlico-Lodi (WPL) and Luning-Berlin (WLB) assemblages of the Walker Lake terrane and the Gold Range assemblage (Jkgor), a coarse clastic and shallow marine unit of Jurassic age has been mapped as the Dunlap Formation (Stewart and Carlson, 1978). It lies unconformably over both Permian and Triassic rocks (Oldow, 1981), and disconformably over other Triassic and Lower Jurassic rocks
(Oldow and Bartel, 1987). Some of the rocks mapped as Dunlap likely belong in unit $\mathrm{Jcg}$, however, it is not consistently defined on the Nye, Mineral, and Esmeralda County maps, and in many places rocks originally mapped as Dunlap have turned out to be a variety of other units. The Dunlap Formation therefore has not been separated from the other Mesozoic rocks on this map at this time, but it may belong with a more regional Jcg unit that defines an important mid-Mesozoic tectonic constraint

\section{Gold Range Assemblage}

\section{Jkgor Terrigenous clastic and volcanogenic rocks} (Lower Jurassic and Upper Triassic) The Gold Range assemblage consists of mainly nonmarine, terrigenous clastic, and volcanogenic rocks of probable Late Triassic to Middle Jurassic ages, and local volcanic rocks having younger Mesozoic radiometric ages (Silberling, 1991). It is lying with angular unconformity over Permian rocks included in the Golconda terrane (GC). The oldest rocks are interbedded, subaerial and shallow-marine terrigenous clastic, volcaniclastic, and minor carbonate rocks overlain by shelf carbonates containing Early Jurassic pelecypods. Unfossiliferous quartz arenite and coarse clastic rocks disconformably overlie the shelf carbonate and grade upward into poorly sorted volcanogenic sandstone and coarse clastic rocks (Oldow, 1984a; Oldow and Bartel, 1987). The assemblage is deformed by northeast-trending folds associated with the overlying Luning thrust as well as younger northwest-trending folds (Oldow, 1984a). Archbold and Paul (1970) named these rocks the Gold Range Formation. They were originally mapped as the Luning Formation and in a few cases, the Excelsior Formation by early workers (Archbold and Paul, 1970, p. 6). Speed (1977a) later modified the definition of the Gold Range Formation. Oldow (1981) included some of these rocks in the Water Canyon assemblage. These rocks were included with the Paradise terrane (Silberling, Jones, and others, 1987; Silberling, Jones, and others, 1992), but have been separated here in agreement with Silberling (1991). Silberling (1991) used "Gold Range terrane" to include the unconformably underlying Permian rocks of the Mina Formation. Since the 
basement rocks are here included with the Golconda terrane, the term "Gold Range assemblage" is used only for the Mesozoic rocks unconformably overlying the Permian basement. The Gold Range assemblage is in the same tectonostratigraphic position as the Humboldt assemblage- - both are overlying rocks of the Golconda terrane with a strong angular unconformity. While these assemblages are similar in overall age, they have different stratigraphic sequences and thus paleogeographic settings. The exact stratigraphy of the Gold Range assemblage and whether or not it includes younger Cretaceous volcanic rocks (Silberling, Jones, and others, 1987; Stewart, 1980) is not clear. This assemblage crops out in Esmeralda, Mineral, and northern Nye Counties

\section{Humboldt Assemblage}

A thick carbonate and clastic sequence of Triassic and Early Jurassic age ( $\mathrm{kc}, \mathrm{J}$ Ks) was deposited on top of the Lower Triassic volcanic Koipato Group ( $k$ kv) throughout a large area of Pershing, Churchill, and Lander Counties (Oldow, 1984a). These sedimentary rocks crop out in central Nevada and are geographically isolated and stratigraphically distinct from stratigraphic sequences to the east. They exhibit varying degrees of deformation, but can still be defined as coherent sequences of strata. They may be paleogeographically related to rocks of similar ages and facies that are part of accreted terranes now located to the west, but each terrane and assemblage has somewhat different structural and stratigraphic characteristics.

JKs Shale, siltstone, sandstone, and minor carbonate (Lower Jurassic to Upper Triassic)— Rocks of the Grass Valley, Osobb, and Dun Glen Formations, and their unnamed overlying rocks elsewhere known as the Winnemucca Formation, exposed in Pershing, Churchill, Lander, and Humboldt Counties, characterize this unit. These rocks are depositional on top of the Star Peak Group carbonate and detrital rocks ( $\mathrm{k} \mathrm{c}$ ). Crossbedding, lode casts, and other depositional features indicate uniform northwest-trending current directions. The lithology and depositional characteristics of these rocks suggest shallow marine conditions on and around a westerly prograding delta (Silberling and Wallace, 1969). Fossils from these rocks range in age from Late Triassic (Norian) to Early Jurassic (Toarcian) (Silberling and Wallace, 1969) glomerate (middle Upper to upper Lower

Triassic (Carnian to Spathian))_Unit consists of the Star Peak Group which lies depositionally on the volcanic and volcaniclastic rocks of the Koipato Group ( $\mathrm{k} k v$ ). Map unit includes rocks mapped as Cane Spring, Natchez Pass, Prida, Augusta Mountain, Congress Canyon, Fossil Hill, Favret, Dixie Valley, and Tobin Formations, including Smelser Pass, Panther Canyon, and Home Station Members of the Augusta Mountain Formation. Basaltic flows and volcanic breccias ( $\mathrm{k} \vee \mathrm{m}$ ) are present in the Humboldt and northern Stillwater Ranges within the Smelser Pass Member of the Augusta Mountain Formation. The Star Peak Group includes carbonate platform deposits and grades westward into slope and basin paleogeographic environments. Complex stratigraphic patterns of carbonate and terrigenous rocks in the lower part of the group result from localized relative uplift. Widespread diagenetic secondary dolomitization of calcareous rocks complicates the stratigraphic patterns (Nichols and Silberling, 1977b). There is a major unconformity within the Star Peak Group underneath the Panther Canyon Member, which is late Ladinian (late Middle Triassic) in age. The Panther Canyon Member rests in places directly on the noncarbonate rocks of either the Koipato Group ( $\mathrm{k} \mathrm{kv}$ ) or the Golconda terrane (GC), and elsewhere on varying thicknesses of secondary dolomite that replaces Star Peak Group carbonate rocks. The Star Peak Group crops out in Churchill, Humboldt, Lander, and mostly Pershing Counties. Abundant fossil data from the Star Peak Group indicates this unit is latest Early (Spathian) to middle Late (Carnian) Triassic in age (Nichols and Silberling, 1977b)

\section{Siliciclastic Overlap Assemblage}

The Candelaria Formation ( $\mathrm{kcl}$ ) is the only Mesozoic unit grouped with the Siliciclastic overlap assemblage $(\mathrm{K} \mathrm{cl}$, Pacl, PPacl) which is discussed in detail under Paleozoic rocks.

$\mathrm{K} \mathrm{cl}$ Shale, sandstone, and limestone (Lower Triassic)_Shale with interbedded sandstone and minor limestone characterize the Lower Triassic Candelaria Formation (Ferguson, Muller, and Cathcart, 1954). This vertically coarsening sequence grades up into a distal volcanogenic turbidite in the middle and a proximal turbidite and breccia near the top (Stewart, 1980). The 
basal strata of the Candelaria are earliest Triassic (Griesbachian) and the highest are late Early Triassic (early Spathian) (Speed, Silberling, and others, 1989). It is equivalent in age to the marine Dinwoody Formation of northwestern Utah and southeastern Idaho, and possibly, to the lower part of the predominantly volcanic Koipato Group in northwestern Nevada (Poole and Wardlaw, 1978). The Candelaria Formation is mainly exposed near the old mining camp of Candelaria, located a little more than $20 \mathrm{mi}$ south of Mina, in Mineral County. Another exposure also has been described from the southern Toquima Range in Nye County, and a collection of Early Triassic fauna was recovered from flaggy brown siltstone from the west side of the Toiyabe Range east of Ione (Poole and Wardlaw, 1978). Early Triassic conodonts in clastic rocks in the northern Hot Creek Range near Morey Peak suggest that some of these rocks may also be correlative with the Candelaria. These additional Early Triassic locals suggest that the Candelaria may have been more extensive, or is still unrecognized elsewhere in the central part of the State. The nature of the basal contact is critical to determining the appropriate paleogeographic setting and regional grouping for this unit. If the basal contact is a major structure, then the Candelaria likely represents a section of one of the many Mesozoic terranes that have been emplaced from the west. If the contact is fundamentally sedimentary, albeit disconformable or unconformable, then it constrains an important piece of the paleogeographic tectonic puzzle of Nevada geology. The Candelaria Formation lies on the subjacent Permian Diablo Formation where it is described as unconformable by Ferguson and others (1954), conformable by Speed and others (1977, p. 303), and nearly conformable by Page (1959). The Candelaria near Willow Spring in the Toquima Range is described as a "probable unconformity" by Poole and Wardlaw (1978). The regional map relations for this unit suggest that the base is a disconformity or slight unconformity with the underlying Diablo Formation (Ferguson, Muller, and Cathcart, 1954; Page, 1959), but not a major structure. The Diablo Formation, included here with the Permian siliciclastic overlap assemblage, lies with marked unconformity on lower Paleozoic basinal rocks of chert, argillite, and shale, as discussed below. The Candelaria Formation is unusual in that it is the oldest Mesozoic sedimentary sequence known in Nevada, and is present in a restricted area only over the Permian rocks of the Siliciclastic overlap assemblage, which also suggests that it was originally deposited directly on those rocks. The presence of volcaniclastic rocks in the upper part of the section is an important tectonostratigraphic link to the rocks of adjacent terranes. Rocks near Quinn River, Nevada that are almost as old and contain volcaniclastic rocks in the upper part of the section, belong to the Black RockJackson terrane (Blome and Reed, 1995; Jones, 1990). Triassic rocks of similar age exposed south of Jarbidge in northeastern Elko County are juxtaposed with Permian rocks of the Siliciclastic overlap assemblage and may correlate with the Candelaria, but the base of the section is unknown and no volcanic facies are reported from those rocks, so they are currently included with the Cratonal sequence, $\mathrm{kmt}$

\section{Cratonal Sequence}

Marine and continental deposits of Triassic and Jurassic rocks crop out east of $116^{\circ}$ longitude. They can be correlated with similar deposits present to the east on the Colorado Plateau and eastward across the western United States. The older Triassic rocks are marine ( $\mathrm{k} \mathrm{mt}$ ) and grade upward in a depositional sequence into continentally derived rocks (J $\mathrm{k}$ ch) and crossbedded sandstone (Jas).

Jas Eolian crossbedded sandstone (Jurassic)-Consists of the Aztec Sandstone. Unit is a friable fine- to medium-grained sandstone with conspicuous large scale cross-strata (Stewart and Carlson, 1978). It is considered eolian. Its age is wholly Jurassic and does not include Triassic rocks as indicated on the 1978 State map (Stewart, 1980). The Aztec is the westward continuation of the Navajo Sandstone of the Colorado Plateau. It crops out only in southern Nevada in Clark and Lincoln Counties

J Kch Continentally derived siltstone and clay (Lower Jurassic and Upper Triassic)—These continental deposits include variegated bentonitic claystone, siltstone, and clayey sandstone, ledge-forming sandstone, and red siltstone (Stewart and Carlson, 1978). The lower part of this unit is equivalent to the Upper Triassic Chinle Formation and the upper part corresponds to the Moenave and Kayenta Formations which are now 
considered Lower Jurassic (Stewart, 1980). It crops out in Elko, Lincoln, and Clark Counties

kmt Marine siltstone, limestone, and conglomerate (Middle(?) and Lower Triassic)—Unit consists of marine deposits of siltstone, sandstone, claystone, mudstone, limestone, and conglomerate (Stewart and Carlson, 1978). It includes rocks assigned to the Moenkopi and Thaynes Formations and related unnamed rocks in northern Nevada (Stewart, 1980). It crops out in the eastern part of the State in Elko, White Pine, Lincoln, and Clark Counties

\section{Paleozoic Rocks}

The interpretation of Paleozoic rocks in Nevada has had a long and colorful history that is almost as interesting as the rocks themselves. Paleozoic rocks in Nevada are here grouped into nine categories that include stratigraphic sequences, lithologic assemblages, and accreted terranes. These groupings were chosen to best represent the similarities and differences among different rock units.

- In the eastern third of the State, the Carbonate shelf sequence includes Cambrian through Permian rocks and their metamorphosed equivalents. While these rocks have seen significant post-Paleozoic disruption in places, the regional pattern of these rocks is one of either continuous conformable or disconformable sequences. Major unconformities are not part of this sequence.

- The Siliciclastic overlap assemblage is a Pennsylvanian through Lower Triassic sequence of siliciclastic and carbonate rocks that lies above a major unconformity over several other assemblages and terranes. It lies disconformably on Pennsylvanian Carbonate shelf sequence rocks and on the Foreland basin assemblage, and with major unconformity on lower Paleozoic rocks of the Slope assemblage, the Basin assemblage, the Nolan belt, and the Dutch Flat terrane. Its sparse regional distribution but consistent stratigraphic (and structural) position makes it an important regional tectonic constraint. Lower Triassic rocks of the Siliciclastic overlap assemblage only are exposed in southwestern and south-central Nevada.

- The Foreland basin assemblage is an Upper Devonian through Lower Pennsylvanian siliciclastic sequence deposited on the western part of the Carbonate shelf sequence. There may be unconformities within the Foreland basin assemblage, but much of the sequence is conformable or disconformable, and lithologies above and below any breaks are similar, making them difficult to identify.
- In a north-south belt in the east-central part of the State, Ordovician through Lower Mississippian rocks are grouped into the Slope assemblage. In places parts of this assemblage are in conformable depositional contact with Carbonate shelf sequence rocks, and fairly coherent stratigraphic sequences can be defined. In most places, these rocks are imbricated in thrust sheets with rocks of both the Carbonate shelf sequence and the Basin assemblage. The lithologies of the Slope assemblage reflect deeper slope and basin depositional settings than their coeval Carbonate shelf sequence counterparts.

- Rocks of the Basin assemblage are exposed in a belt trending southwest and south from northeastern Nevada towards Esmeralda County. These Upper Cambrian through Devonian rocks are characteristic of deep marine paleogeographic settings and include both sedimentary rocks and occasionally their mafic volcanic substrate. Apart from fragments of basaltic rocks, no basement is preserved with these rocks, and they are structurally emplaced over other generally coeval rocks. In many places they are intimately imbricated with Slope assemblage rocks, and in some places they are imbricated with Carbonate sequence rocks. While biostratigraphic evidence indicates that these rocks range from Upper Cambrian through Devonian, few stratigraphic sequences can be defined within these strongly deformed rocks. The amount of displacement experienced by the rocks in this assemblage is unknown and likely highly variable.

- A belt of lower Paleozoic rocks with strong affinity to the North American continental margin but with unusual structural characteristics forms a discrete belt west and northwest of displaced rocks of the Slope and Basin assemblages, and is here named the Nolan belt. They are different from the other Paleozoic rocks in a number of important ways that warrant distinction as a separate group. These rocks have structural characteristics of an accreted terrane, that is, they exhibit polyphase deformation, but have stratigraphic ties to North America that suggest they have not traveled great distances laterally from the continental margin. The three principal characteristics that define the Nolan belt of rocks are that (1) lithologically they define a region of outer shelf and slope Cambrian and Ordovician rocks, originally deposited in a more proximal position to the Carbonate shelf sequence than the rocks of the Basin assemblage, some of which now lie structurally to the east of this belt, (2) unlike rocks of the Basin or most of the Slope assemblage, they are stratigraphically attached to their Precambrian to Cambrian quartzite basement, and (3) they exhibit a unique polyphase deformation history distinct from adjacent coeval rocks. 
Two Paleozoic terranes are included, in addition to the Black Rock terrane described in the Mesozoic terranes section which also contains Paleozoic rocks. These terranes represent groups of rocks that have a range of ages and lithologies, but share structural or tectonic characteristics that indicate they have a common structural history that is distinct from the history of adjacent rocks. Some of these rocks may be displaced only tens of kilometers from their places of origin, while others may be displaced by thousands of kilometers. The rocks in these terranes also have tectonic histories distinct from the rocks of the continental margin prior to the time of their accretion. The terranes were accreted by a combination of translational and compressional movement leading to large steeply dipping fault zones and many imbricate slices of deformed rocks along the boundaries between these terranes and the continental margin.

- The Golconda terrane is a strongly deformed group of Upper Devonian through Middle Permian deep basinal sedimentary, distal shelf clastic, volcaniclastic, and volcanic rocks. The only basement known for the Golconda terrane is slivers of Mississippian to Permian ocean floor mafic and ultramafic rocks interleaved with the deep marine sedimentary and clastic rocks. It is structurally emplaced over Pennsylvanian and Permian rocks of the Siliciclastic overlap assemblage.

- The Late Devonian or younger Dutch Flat terrane is represented by the Harmony Formation, feldspathic sandstone long thought to be Cambrian. It is unconformably overlain by Pennsylvanian rocks of the Siliciclastic overlap assemblage providing an upper age limit. Its contacts with adjacent rock units are structural. It has a unique structural history and unique lithologic characteristics. Its origin and mode of emplacement remain uncertain.

- Finally, the Paleozoic rocks of the Black Rock-Jackson terrane exposed in northwesternmost Nevada have stratigraphic and structural affinities with coeval rocks in the eastern Klamath Mountains. These rocks were accreted to other Mesozoic rocks in Nevada during Jurassic and (or) Cretaceous time.

\section{Sedimentary and Metamorphic Rocks}

\section{Carbonate Shelf Sequence}

In the eastern third of the State, the Carbonate shelf sequence includes Cambrian through Permian rocks and their metamorphosed equivalents. While these rocks have seen significant post-Paleozoic disruption in places, the regional pattern of these rocks is one of either continuous conformable or disconformable sequences. Major unconformities are not part of this sequence, although disconformities are. The Carbonate shelf sequence rocks are principally carbonate and dolomite, with lesser amounts of shale, sandstone, quartzite, and other clastic rocks typical of middle inner shelf to platform margin depositional environments. Metamorphic equivalents are also present in Cambrian through Devonian rocks and are included in the next section. Two clastic units, the Middle and Upper Ordovician Eureka Quartzite (Ocq) and the Lower Permian siltstone and sandstone (Psc), are also part of this sequence, the former serving as an important marker horizon in the Ordovician rocks, and the latter indicating a period of extended subaerial deposition during the Early Permian across the region. The area of exposure of the Carbonate shelf sequence of rocks generally defines the extent of the Paleozoic continental shelf, although locally this area has been significantly modified as the result of post-Paleozoic tectonism. The Cambrian through Devonian sequence of shelf rocks can be broken out reasonably well according to the depositional sequences discussed in Cook and Corboy (2004), which is similar to, but provides more detail than the groupings used in Stewart and Carlson (1978). Units DSc and SOc are not uniformly broken out across their area of exposure. In some places unit DSc is lumped with unit SOc, in other places unit SOc is lumped with unit O€c. The resulting local differences in the stratigraphic section are largely an artifact of the map units, but may locally be caused by the irregular distribution of these units.

Pc Cherty limestone, dolomite, shale, and sandstone (Middle to Lower Permian)-These Permian rocks include cherty limestone, dolomite, shale, sandstone, bioclastic limestone, and phosphatic limestone exposed in Elko, White Pine, Lincoln, and Clark counties. This unit includes rocks mapped as the Phosphoria Formation; the Gerster Limestone, Plympton Formation, Kaibab Limestone, and Grandeur Formation of the Park City Group; the Park City Group undivided; the Toroweap Formation; and the Coconino Sandstone. Unit Pc is disconformably overlain by Triassic unit $\mathrm{kmt}$ in scattered places in eastern and southern Nevada. It depositionally overlies unit Psc. It matches closely with unit Pc of Stewart and Carlson (1978)

Psc Siltstone, sandstone, limestone, and dolomite (Lower Permian, Leonardian and Wolfcampian)-This largely siliciclastic unit of siltstone, sandstone, limestone, and dolomite crops out in Elko, White Pine, Lincoln, and Clark Counties. It includes rocks originally mapped as the Arcturus Formation, Rib Hill Sandstone, undivided Kaibab Limestone, Toroweap Formation, and Coconino Sandstone in Clark County; and the Pequop Formation and red beds in Lincoln County. Unit Psc represents a strong influx of clastic material over the carbonate shelf during the Early Permian, presumably derived 
primarily from the craton to the east. It is depositionally overlain by unit $\mathrm{Pc}$ and lies conformably above unit PPc. At its western and northern edges it can be difficult to distinguish from Permian clastic rocks of the Siliciclastic overlap assemblage (units Pacl and PPacl). It follows closely with unit Psc of Stewart and Carlson (1978)

PPC Limestone, dolomite, siltstone, sandstone, and shale (Lower Permian and Pennsylvanian)_-Present in Elko, White Pine, Lincoln, and Clark Counties. This unit represents mostly Upper Pennsylvanian and Lower Permian rocks that have not otherwise been separated into units Psc or PMbc. Unit includes unnamed Pennsylvanian and Lower Permian limestone and sandstone beds in Lincoln County, the Bird Spring Formation in Clark County, the Riepe Spring and Ely Limestones (undivided) in White Pine County, and limestone and dolomite rocks not otherwise assigned in Elko County. This unit lies depositionally below unit Psc and above the Ely Limestone (PMbc) where it is mapped separately. Where unit PMbc is not mapped separately in southern Nevada, the unit lies directly on Mississippian carbonate (Mc) and in White Pine County it rests on undivided Chainman and Pilot Shales and Joana Limestone (shown as either unit $\mathrm{PMcl}$ or $\mathrm{MDcl}$ )

PMbc Bioclastic limestone (Pennsylvanian and Upper Mississippian)-Mostly Lower Pennsylvanian limestone is present in Nye, Elko, Eureka, White Pine, Lincoln, and Clark Counties, and is most commonly referred to as the Ely Limestone. A ledgy gray limestone mapped as the Moleen Formation is included here. It is not mapped separately from unit PPc in most of White Pine County, southeastern Elko County, southern Lincoln, and western Clark Counties. Throughout most of the area of exposure unit lies conformably or disconformably beneath unit PPC and depositionally above unit $\mathrm{PMcl}$. In southern Nye County this unit includes the Tippipah Limestone, and in Clark County it includes the Callville Limestone. In a north-south trending belt starting at the north end of the Pancake Range in Nye County and continuing north up through the Diamond Mountains along the Eureka-White Pine County border, Lower Pennsylvanian limestone is overlain unconformably by

clastic rocks of the Siliciclastic overlap assemblage (Pacl, PPacl). North of the Diamond Mountains, where Lower Pennsylvanian carbonate is not recognized separately, the coeval facies are grouped with unit $\mathbb{P M c l}$. Unit $\mathbb{P M b c}$ is primarily Pennsylvanian, but in places contains Late Mississippian fossils as well

Mc

Dc

Dcd
Limestone (Mississippian)_-This unit is present in southern Nye, Lincoln, and Clark Counties. Unit includes the Monte Cristo Limestone, and Lower Mississippian rocks referred to as the Joana, Mercury, Bristol Pass, and Rogers Spring Limestones. It generally lies depositionally above Devonian carbonate rocks and beneath Pennsylvanian carbonate and clastic rocks. In the Meadow Valley Mountains in southern Lincoln County it is also shown sitting on a thin horizon of Pilot Shale and overlain by a thin Mississippian clastic unit assigned to unit $\mathrm{PMcl}$

Limestone and minor dolomite (Upper and Middle Devonian)_-Includes generally cliff-forming, thin- to thick-bedded limestone. These rocks are mainly shallowwater subtidal, intertidal, and supratidal deposits formed on a broad inner carbonate shelf (Stewart, 1980). The Devils Gate Limestone and Guilmette Formation in northern Nevada are the principal units, and the Sultan Limestone is included from the southern part of the State. Unit is overlain (usually disconformably) by the Pilot Shale of unit MDcl except in southernmost Nevada where it is overlain by Mississippian carbonate (Mc). It depositionally overlies Middle and Lower Devonian unit Dcd. In a few places, such as southern Nevada and parts of Eureka County, regional mapping did not distinguish the Upper and Middle Devonian section from the Lower Devonian section, and all of the Devonian is included in unit Dc. Rocks mapped as the Simonson Dolomite would fit into this depositional sequence (sequences 9 and 10 of Cook and Corboy, 2004), but they are not differentiated from the underlying dolomites in White Pine or Elko Counties, so they are all included in unit Dcd here, not unit Dc. This unit crops out in Clark, Elko, Eureka, Lander, Lincoln, Nye, and White Pine Counties

Dolomite, sandstone, and limestone (Middle and Lower Devonian)_Crops out over the same area as unit Dc. Its primary formations are the Sevy Dolomite and the Nevada 
Formation (now abandoned). In White Pine County, there may be some undivided Guilmette Formation included with unit Dcd. Also included are the Lower Devonian Tor and McMonnigal Limestones in northern Nye County. The Simonson Dolomite is also included here as it is not differentiated in White Pine and Elko Counties. These rocks correspond to depositional sequences 6, 7, and 8 of Cook and Corboy (2004). Unit Dcd is overlain by unit Dc and is depositional on DSc. In White Pine County and most of Elko County, unit DSc is not broken out from unit SOc, hence the Devonian dolomite sequence appears to rest directly on $\mathrm{SOc}$

DSc Dolomite (Lower Devonian and Silurian)_Unit corresponds with sequence 5 of Cook and Corboy (2004) and includes the Laketown and Lone Mountain Dolomites and equivalent unnamed rocks. In White Pine County these rocks are grouped with the underlying unit SOc, but otherwise are mapped in Elko, Eureka, Nye, Lincoln, and Clark Counties. Disconformities and discontinuities are commonplace along both upper and lower contacts (Langenheim and Larson, 1973). Unit DSc is depositionally overlain by unit Dcd, except where those rocks are grouped with unit Dc. In general, unit DSc overlies unit SOc. In Clark County and parts of Elko County, unit SOc is not differentiated from unit $\mathrm{O} € \mathrm{c}$, and therefore DSc lies directly on $\mathrm{O} C \mathrm{c}$. In the Sulphur Spring Range, DSc depositionally overlies unit DSt, and in the Roberts Mountains it grades laterally and vertically down into unit DSt. The Lone Mountain Dolomite has been shown to be both primary and secondary dolomite (Nichols and Silberling, 1977a). Therefore the boundaries mapped between unit DSc and both underlying DSt and overlying Dcd are not primary depositional features in all cases, especially in the Roberts Mountains

SOc Dolomite, limestone, and shale (Lower Silurian to Middle Ordovician)_Ely Springs Dolomite and Hanson Creek Formation are the main formations included in this unit. Many of the rocks in this unit are not assigned to a formation. A large section of the carbonate platform from Early Devonian through latest Ordovician time is represented by dolomitic rocks. They commonly look similar, have poor biostratigraphic control, and thus are not always well differentiated on the county maps. Additionally, not all of the dolomite is primary, and thus boundaries between secondary dolomite and other rock units have been misinterpreted as primary stratigraphic boundaries, further confusing the stratigraphy of the lower Paleozoic shelf (Nichols and Silberling, 1977a). Rocks in this unit correspond to sequence 4 of Cook and Corboy (2004). This unit includes rocks deposited immediately above the Eureka Quartzite, but disconformably below the Lone Mountain and Laketown Dolomites, hence it includes the Silurian and uppermost Ordovician. Rocks included in unit SOc that are mapped as the Hanson Creek Formation are depositionally overlain by the Roberts Mountains Formation of unit DSt in the northern and western part of the exposure area. The SOc rocks mapped as Hanson Creek Formation are difficult to distinguish from units DSt and DOts, and should more appropriately be included in unit DOts, but inconsistent mapping makes this difficult. In general unit SOc is not differentiated from unit $\mathrm{O} € \mathrm{c}$ in Clark County, and thus unit $\mathrm{DSc}$ lies directly on unit O€c. In Lincoln and Nye Counties unit SOc lies directly on the Eureka Quartzite (Ocq) and is overlain by the Laketown Dolomite (DSc). In southern Nye County, rocks mapped as Ely Springs Formation are grouped with the Eureka Quartzite as unit Ocq. In White Pine and eastern Elko Counties, the Eureka Quartzite is not mapped separately, and unit SOc therefore lies directly on unit $\mathrm{O} € \mathrm{c}$, which includes the quartzite. Also in White Pine and eastern Elko Counties, unit DSc is not differentiated from unit SOc, so SOc is overlain directly by unit Dcd. In the northern and western areas of exposure where unit SOc is mapped as Hanson Creek Formation it is overlain depositionally by unit DSt of the Slope assemblage

Quartzite (Middle Ordovician)—Because of its importance as a stratigraphic marker horizon, the Eureka Quartzite is depicted on this map wherever it is mapped separately from the Ordovician carbonate shelf rocks. It represents depositional sequence 3 of Cook and Corboy (2004). It is not differentiated from the rest of the Ordovician $(\mathrm{O} € \mathrm{c}$ ) in White Pine or Clark Counties, but is shown in Elko, Eureka, Nye, and Lincoln Counties. Rocks mapped as the Ely Springs Dolomite are included with the Eureka Quartzite in southern Nye County. The Eureka Quartzite depositionally overlies the Pogonip Group 
$(\mathrm{O} \in \mathrm{c})$, and is overlain by either the Hanson Creek Formation or the Ely Springs Dolomite (SOc)

O€c Limestone, dolomite, and quartzite (Middle Ordovician to Upper Cambrian)Carbonate platform rocks are present in Nye, Lincoln, Elko, Eureka, Lander, White Pine, Esmeralda, and Clark Counties. This unit is primarily Ordovician in age but does include Upper Cambrian rocks at the base (Page, Lundstrom, and others, 2005). The Pogonip Group, including the Antelope Valley Limestone is the most common name used. In Clark County it also includes the Ely Springs Dolomite, and includes the Eureka Quartzite in White Pine and Clark Counties. Unit $\mathrm{O} \in \mathrm{c}$ corresponds to depositional sequence 2 of Cook and Corboy (2004). Where Ocq is mapped separately, it overlies $\mathrm{O} €_{c}$. Otherwise $\mathrm{O} €_{\mathrm{c}}$ is depositional under SOc, or in southern Nye and Clark Counties, it is overlain directly by DSc where SOc is not differentiated. Unit $\mathrm{O} €_{c}$ depositionally overlies unit $\ell_{c}$

$€ c$

Dolomite, limestone, and shale (Cambrian)Occurs in southern and eastern Nevada. The Bonanza King and Carrara Formations are the primary formations in southern Nye County; the Dunderberg Shale in northern Nye and Lincoln Counties; the Hamburg Dolomite in Eureka County; the Nopah Formation in southern Nye and Esmeralda Counties; the Patterson Pass and Pioche Shales, the Chisholm and Highland Peak Formations, and the Lyndon Limestone in Lincoln County; the Pole Canyon Limestone and the Lincoln Peak and Windfall Formations in northern Nye County; and undifferentiated limestone and dolomite in Lincoln, Clark, White Pine, Eureka, northern Nye, and Elko Counties. This unit is conformably overlain by the Ordovician shelf rocks $(\mathrm{O} \mathrm{Cc}$ ), and is depositional on the underlying Proterozoic-Cambrian quartzite of $€ Z q$

Undivided and Metamorphosed Carbonate Shelf Sequence Rocks

DEc Dolomite and limestone (Middle Devonian to Upper Cambrian)_Lower Paleozoic dolomite and limestone present in southeastern Lincoln and Clark Counties are grouped together into unit $D \in c$. The lower Paleozoic section is too thin to map regionally as individual units, and the structure is too complex in these rocks to accurately portray the individual units at this scale. In part of Clark County, these rocks are referred to as the Goodsprings Dolomite. In the Mormon Mountains of Lincoln County, these rocks are overlain by Mississippian carbonate (Mc). In Clark County in the Spring Mountains, they are overlain by the Devonian Sultan Limestone (Dc)

DOcm Dolomite and graphitic marble (Devonian to Upper Ordovician)—Occurs in the Ruby Mountains, East Humboldt Range, and Wood Hills in Elko County and overlies the metamorphosed Eureka Quartzite (Ocqm)

Ocqm Metaquartzite (Middle Ordovician)—The metamorphosed Eureka Quartzite is shown separately in the Ruby Mountains, East Humboldt Range, and Wood Hills in Elko County, and serves as a valuable marker horizon for the thick sequence of metamorphosed lower Paleozoic shelf rocks

O€cm Calcite marble (Middle Ordovician to Cambrian)-Underlies the metamorphosed Eureka Quartzite marker horizon in the Ruby Mountains, Wood Hills, and Pequop Mountains in Elko County

\section{Terranes and Assemblages}

\section{Golconda Terrane}

GC Basinal, volcanogenic, terrigenous clastic, and minor carbonate rocks (Permian to Upper Devonian) - The Golconda terrane is composed of deformed and imbricated thrust slices of upper Paleozoic rocks including deep-marine, pelagic and turbiditic, carbonate, terrigenous clastic and volcaniclastic rocks, radiolarian chert and argillite, and pillow basalt (Silberling, Jones, and others, 1992). While the terrane is characterized by a great diversity of rock types, all rocks are strongly deformed with an east-vergent fabric, a distinguishing characteristic of this terrane (Brueckner and Snyder, 1985; Jones, 1991a; Miller, Kanter, and others, 1982; Murchey, 1990; Stewart, Murchey, and others, 1986). It crops out in a long sinuous belt, up to $100 \mathrm{mi}$ wide in places. Southwest of Mina, the belt trends east from the California border to just north of Tonopah, and then bends north-south to the west of Longitude $117^{\circ}$ to about $50 \mathrm{mi}$ north of Winnemucca, where it bends again, 
sharply to the east-north of Tuscarora with significant exposures eastward and to the northern border of the State. Outcrops of the Golconda terrane are present in Mineral, Esmeralda, northern Nye, Churchill, Elko, Humboldt, Lander, and Pershing Counties. It includes some rocks originally mapped as Banner and Nelson Formations in Elko County; rocks originally mapped as the Excelsior Formation in Mineral and Esmeralda Counties, later assigned to the Black Dyke and Mina Formations by Speed (1977b); the original Havallah and Pumpernickel Formations (Muller, Ferguson, and Roberts, 1951; Roberts, 1964; Silberling and Roberts, 1962), later revised to structural sequences (Murchey, 1990; Stewart, MacMillan, and others, 1977; Stewart, Murchey, and others, 1986; Theodore, 1991; 1994) in Elko, Humboldt, Lander, and Pershing Counties; the Inskip Formation in Pershing County; the Mitchell Creek Formation in Elko County; the Pablo Formation in northern Nye County; and the Schoonover Formation (see unit GChr) in Elko County.

In all of the places where rocks of the Golconda terrane were originally believed to form a stratigraphic sequence, detailed mapping and biostratigraphic analysis with radiolarians and conodonts has demonstrated that it is characterized by complex imbrications of rocks ranging from mid-Permian through latest Devonian age (Holdsworth, 1986; Jones, 1991b; Miller, Holdsworth, and others, 1984; Murchey, 1990; Stewart, MacMillan, and others, 1977). In Pershing County, the Golconda terrane is unconformably overlain by Triassic volcanic rocks of the Koipato Group ( $\mathrm{k} k \mathrm{k}$ ) which form the stratigraphic base to the Humboldt assemblage ( $\mathrm{kc}, \mathrm{Jks}$ ). In Mineral and Esmeralda Counties, it is unconformably overlain by the Gold Range assemblage (J kgor) of mainly nonmarine, terrigenous clastic, and volcanogenic Upper Triassic and younger rocks. Elsewhere in northern and southwestern Nevada, it is structurally overlain by Mesozoic accreted terranes.

Across the length of its exposure from the Independence Mountains north of Elko to the Candelaria region south of Mina, the base of the Golconda terrane has a remarkably consistent structural emplacement relationship with adjacent rocks. It commonly lies on a low-angle structure above Permian and Pennsylvanian rocks of the Siliciclastic overlap assemblage. In places where these rocks are missing, it is faulted directly onto either the nearby lower Paleozoic Basin assemblage, the Nolan belt rocks, or the Harmony Formation of the Dutch Flat terrane. The type locality of this regional feature, the Golconda thrust is well exposed along Interstate Highway 80 at Edna Mountain near the town of Golconda (Ferguson, Roberts, and Muller, 1952), and in the open pits of mines near Battle Mountain (Theodore, T., oral commun., 2006). In southwestern Nevada, the lower Lower Triassic rocks of the Candelaria Formation overlie Permian and Pennsylvanian Siliciclastic overlap assemblage rocks, and the Golconda terrane is exposed nearby, but not observable directly on top of the Candelaria because of younger cover rocks. Elsewhere, there is no youngest age constraint for the age of emplacement. In several places, notably in the Osgood Mountains and the Toiyabe Range, it is also bounded by large, steeply dipping, mélange-like shear zones against older rocks of the Nolan belt. Stratigraphic and structural studies within the terrane have locally identified lithostratigraphic groupings (Erickson and Marsh, 1974a, b; Jones, 1991a; Murchey, 1990), but only the Home Ranch subterrane can presently be distinguished on a regional scale (GChr). Interpretations of the size and character of the late Paleozoic basin where these rocks formed and the nature of its Late Permian or Early Triassic accretion are as varied as the lithologic and structural characteristics of the terrane itself (see references above)

\section{GChr Home Ranch subterrane (Mississippian)-}

Limestone, basalt, chert, and volcaniclastic rocks. The Home Ranch subterrane of the Golconda terrane shares similar structural characteristics with the rest of the Golconda terrane, but it has more specific age and lithologic features. It is restricted to Mississippian age (generally Early) and consists of shallow-water fossiliferous limestone, black chert, basalt, and volcaniclastic rocks. Olistostromal debris flows of basalt and limestone, indicative of steep paleotopography, are a distinguishing characteristic (Jones, 1991a). The depositional setting for this subterrane 
can be interpreted as a seamount. It includes rocks in Elko County mapped as the Banner and Nelson Formations, at least parts of the Inskip Formation in the East Range in Pershing County, the Goughs Canyon Formation in the Osgood Mountains, similar rocks in the Hot Springs Range in Humboldt County, and likely includes Mississippian limestone in the San Antonio Mountains in northern Nye County. To what extent these rocks have a history distinct from other rocks of the Golconda terrane is unclear. They are present structurally in a position outboard or west of most other exposures of the Golconda terrane, and are separated in the northern part of the State from other exposures of the terrane by the Nolan belt

\section{Siliciclastic Overlap Assemblage}

The Siliciclastic overlap assemblage is a discontinuous sequence of Pennsylvanian, Permian, and Triassic siliciclastic and carbonate rocks deposited with marked unconformity, usually with a basal conglomerate, over variably deformed Paleozoic rocks of the Dutch Flat terrane (DF), the Nolan belt (O€td, €td), the allochthonous Basin and Slope assemblages (Ss, D€s, DOts, DSt, MDst), the Foreland basin assemblage (PMcl, MDcl), and Pennsylvanian carbonates of the Carbonate shelf sequence (PMbc). The exposures are scattered over a wide area as far west as the Osgood Mountains in Humboldt County and as far east as the HD Range in northeastern Elko County. Exposures are present as far south and west as Candelaria in Mineral County and as far southeast as the Hot Creek Range and possibly into the Pancake Range in eastern Nye County. Outcrops are spotty and discontinuous regionally, but the geologic relations are always very consistent. The regionally significant characteristics of this group are (1) it lies with marked unconformity on deformed older Paleozoic rocks, (2) it is a mixed sequence of siliciclastic and carbonate rocks, commonly with locally derived conglomeratic horizons, (3) it has multiple internal disconformities and unconformities, and (4) it is structurally overlain by rocks of the Golconda terrane (GC) along a low angle structure in many places. The oldest rocks of the assemblage are Middle Pennsylvanian (Atokan), and the youngest rocks of the sequence are Late Permian age, except in southwestern Nevada where the Permian rocks are overlain disconformably by Lower Triassic rocks (unit $\mathrm{kcl}$ is described above under Mesozoic sedimentary rocks). All of the section is not present at all exposures; there is a significant unconformity within the section such that Permian rocks are commonly lying directly on deformed lower Paleozoic rocks. Everywhere except where the rocks lie on the Foreland basin assemblage and Pennsylvanian Carbonate shelf sequence, the unconformity is pronounced and the time gap ranges from as large as Permian overlying Cambrian to as small as
Middle Pennsylvanian overlying Devonian or possibly Lower Mississippian rocks. Where the rocks overlie the Foreland basin assemblage, in some areas the unconformity is marked, such as in Carlin Canyon (Dott, 1955; Trexler, Cashman, and others, 2004), but the lithologies are similar above and below the unconformity-making it difficult to distinguish in areas of poor exposure, and the time gap is much smaller with Middle or Upper Pennsylvanian rocks sitting on Lower or possibly Middle Pennsylvanian rocks (Trexler, Cashman, and others, 2004). Because this assemblage overlaps so many different rocks with distinct tectonic histories, it serves as an important regional age constraint for a number of major Paleozoic tectonic events (Theodore, Moring, and others, 2003). This assemblage is broken into three units that include rocks that are Lower Triassic ( $\mathrm{K} \mathrm{cl})$, Permian (Pacl), and Pennsylvanian to Lower Permian (PPacl). Disconformities or unconformities are present between each of these units. In places where this assemblage has not been broken into separate units it is grouped into unit PPacl. See above under Mesozoic sedimentary rocks for a description of unit $\mathrm{k} c l$.

Pacl Sandstone, siltstone, limestone, conglomerate, and carbonaceous limestone (Permian)Unit is mapped in Elko, Mineral, Humboldt, Lander, Eureka, White Pine, northern Nye, and Esmeralda Counties. Included in this unit are the Carbon Ridge Formation in Eureka and White Pine Counties, parts of the Carlin sequence of Coats (1987), the sandstone and siltstone of Horse Mountain in Elko County, the Edna Mountain Formation in Humboldt and Elko Counties, the Garden Valley Formation in Eureka County, and the Diablo Formation in northern Nye, Mineral, and Esmeralda Counties. In the Candelaria area south of Mina, unit Pacl rests unconformably on deformed Upper Cambrian through Devonian Basin assemblage (D€s) and is overlain by the Lower Triassic Candelaria Formation ( $\mathrm{Kcl}$ ). In the Toiyabe Range, it lies unconformably on deformed Cambrian through Ordovician rocks of the Nolan belt (O€td). In the Simpson Park Mountains and the Sulphur Spring Range, it rests unconformably on Ordovician and Devonian Slope assemblage rocks (DOts). In the Diamond Mountains it rests unconformably on the Ely Limestone (PMbc). In the Eureka area, Pacl unconformably overlies the Ely Limestone (PMbc) and the Diamond Peak Formation (PMcl) and is unconformably overlain by Cretaceous conglomerate (Kcg). Near Golconda it unconformably overlies PPacl. In the Adobe Range in Elko County it overlies Foreland basin assemblage rocks ( $\mathrm{PMcl}$, 
MDcl) and PPacl, and in the Snake Mountains and HD Range of northeast Nevada it lies unconformably on lower Paleozoic Slope and Basin assemblage rocks (D€s, Ss, DOts) and on older Siliciclastic overlap assemblage rocks (PPacl)

$\mathrm{PPacl}$ Conglomerate, sandstone, siltstone, and limestone (Permian to Middle Pennsylvanian)_Unit represents rocks that are stratigraphic sequences that include both Lower Permian and Pennsylvanian rocks, and also sections that have not been broken out regionally into younger and older Permian and Pennsylvanian units. The Antler sequence (Roberts, 1964) rocks are present in Humboldt and Lander Counties and include the Antler Peak Limestone, the Highway Limestone, the Battle Formation or Battle Conglomerate, and the Etchart Limestone. The Brock Canyon Formation of Permian or Pennsylvanian age is in the Cortez Mountains in Eureka County and the siliciclastic and carbonate Strathearn Formation is exposed in Elko County (Theodore, Moring, and others, 2003). Scattered remnants of conglomerate, sandstone, siltstone, and limestone in Nye County, and unnamed limestone and dolomite in Elko County are also included. In the northern Hot Creek Range in Nye County, PPacl is faulted with lower Paleozoic Carbonate shelf sequence rocks. Additionally, Early Triassic fossils in the area have caused reassignment of some of the rocks to the Candelaria Formation $(\mathrm{kcl})$. In the Pancake Range, PPacl lies on the Ely Limestone (PMbc). In the Toquima Range, the Pennsylvanian Wildcat Peak Formation lies unconformably on Slope assemblage rocks (DOts). In the Monitor Range and in Lander County, this unit lies unconformably on the lower Paleozoic Basin assemblage rocks (D€s). At Battle Mountain the Antler sequence lies unconformably on both the Harmony Formation, which is the Dutch Flat terrane (DF), and the Valmy Formation of Basin assemblage unit D€s. At Edna Mountain near Golconda and in the Osgood Mountains it lies unconformably on Cambrian and Late Proterozoic quartzite $(€ Z q)$ and Cambrian phyllite and shale ( $€ t d)$ of the Nolan belt, as well as on units of the Basin and Slope assemblages (D€s, DOts). In the Cortez Mountains of northern Eureka County, it lies unconformably on Basin and Slope assemblage rocks (D€s,
DOts). In the Adobe Range and the Sulphur Spring Range, it lies unconformably on Pennsylvanian and Mississippian Foreland basin rocks ( $\mathbb{P M c l}$ ) (Trexler, Cashman, and others, 2004). In northern Elko County in the Bull Run and Copper Mountains, it lies unconformably on strongly deformed Ordovician to Cambrian rocks of the Nolan belt (O€td). In the Snake Mountains and the HD Range, the Pennsylvanian Quilici Formation lies unconformably on the Basin and Slope assemblages (D€s, DOts, Ss) and is unconformably overlain by the Permian Siliciclastic overlap assemblage rocks (Pacl). In far northeastern Nevada, upper Paleozoic rocks around Contact are very poorly known, but are similar to the Siliciclastic overlap assemblage rocks recognized in the HD range, and are thus included in this group

\section{Foreland Basin Assemblage}

The Foreland basin assemblage is a sequence of Upper Devonian through Lower Pennsylvanian siliciclastic and carbonate rocks deposited disconformably on older Paleozoic rocks of the Carbonate shelf sequence. The boundaries between the Foreland basin assemblage and coeval rocks of the Carbonate shelf sequence migrated east and west as a result of the changing tectonic and depositional settings during this time. Disconformities may be part of this assemblage but are often difficult to identify in these rocks, some of which have limited biostratigraphic control and consist largely of reworked siliciclastic rocks. The primary distinction with coeval rocks to the east in the Carbonate shelf sequence is the principally siliciclastic nature of the units, with a secondary carbonate component. In addition, the source of much of the siliciclastic component is interpreted to be material from the west, as well as from the east. Because of significant Mesozoic and younger structural disruption of these rocks, original stratigraphic relations can be difficult to determine.

\section{PMcl Shale, siltstone, sandstone, and conglomerate (Middle Pennsylvanian to Lower} Mississippian)_Unit crops out across all of eastern Nevada, generally east of $116^{\circ}$ west longitude, and somewhat farther west in the southern half of the State. It includes rocks mapped as the Chainman Shale in Elko, northern Nye, and Lincoln Counties; the Diamond Peak Formation in northern Nye, Elko, Eureka, and White Pine Counties; the Scotty Wash Quartzite in Lincoln County; the upper part of the Eleana Formation in Nye County; and undivided sedimentary rocks in Eureka and Lincoln Counties. Clastic and carbonate rocks mapped in 
Elko County, including undivided Moleen and Tomera Formations (the Tomera Formation includes Middle Pennsylvanian rocks) are also grouped here. Most of these rocks are Upper Mississippian and Lower Pennsylvanian in age, but unit $\mathbf{P M c l}$ also includes Lower Mississippian rocks, overlapping with unit MDcl where they have not been clearly distinguished. In places the Chainman Shale is time transgressive into the Diamond Peak Formation, and in other places they represent different coeval facies, based on limited biostratigraphic data. Where possible, younger siliciclastic rocks have been separated from the older sequence that includes the Pilot Shale and Joana Limestone because of significant differences in the character of the rocks. Unit PMcl is overlain conformably or disconformably in the eastern part of its exposure by carbonate rocks of units PPc and (or) PMbc. In the northern and western parts of its exposure it is overlain unconformably by Permian and Upper Pennsylvanian clastic rocks of the Siliciclastic overlap assemblage (Pacl or P(Pacl). Assignment of siliciclastic Pennsylvanian units to either unit $\mathbb{P M c l}$ or the unconformably overlying PPacl is challenging unless biostratigraphic data are available and outcrop observations reveal the presence of the unconformity such as in Carlin Canyon (Dott, 1955). Unit PMcl lies either conformably or disconformably above unit $\mathrm{MDcl}$

MDcl Siltstone, limestone, shale, and sandstone (Lower Mississippian and Upper Devonian)Unit crops out across all of eastern Nevada, generally east of $116^{\circ}$ west longitude. It includes rocks mapped primarily as Pilot Shale, Joana Limestone, Chainman Shale, and their equivalents. This also includes the Tripon Pass Limestone in Elko County, the Cockalorum Wash Formation (now abandoned) in northern Nye County, the Mercury and Bristol Pass Limestones in Lincoln County, and some of the rocks mapped as Monte Cristo Limestone in Clark County. While it may be desirable to separate out the different lithologies, they are not well enough differentiated at this regional map scale. The Chainman, Joana and Pilot are grouped in White Pine County, and the Joana and Pilot are grouped in Elko County. The Pilot Shale lies depositionally (both conformably and disconformably) on Upper Devonian carbonate rocks (Dc) and signals a major change in the depositional setting across most of the carbonate platform which has long been attributed to the onset of deformation attributed to the Antler orogeny. The Pilot Shale is generally recognized as carbonaceous shale, overlain by the cliff-forming Joana Limestone. Siliciclastic quartz-bearing grit, chert, quartz sand, and siltstone in a calcareous matrix become increasingly common as the section turns into the Chainman Shale and other equivalent siliciclastic rocks. The sequence is interrupted by disconformities in a number of places, but structural disruption and poor age control hinder determination of the nature of the contacts between the distinct lithologies. Unit MDcl is overlain by unit $\mathbb{P M c l}$, but there are places where the age and distinction between the units is poorly constrained. In southernmost Nevada, in Clark and southeastern White Pine Counties, Devonian carbonate is overlain by Mississippian carbonate (Mc) with little or no intervening Pilot Shale equivalent and few overlying siliciclastic rocks with western-derived source material. North and west of the area of exposure of unit MDcl, fault-bounded slivers of Lower Mississippian and Upper Devonian platform margin and slope facies rocks with siliciclastic horizons have been grouped into unit MDst and separated from unit MDcl

\section{Dutch Flat Terrane}

DF Feldspathic sandstone, shale, and turbiditic limestone (Upper Devonian)_-The Dutch Flat terrane is the Late Devonian Harmony Formation. It consists of coarse-graded feldspathic sandstone and siltstone with rare quartzose turbiditic limestone interbeds that have yielded sparse, reworked Late Devonian and post-Ordovician conodonts and conodont fragments (Jones, 1997a; Ketner, Crafford, and others, 2005). The age of the Harmony has never been well constrained. It was originally interpreted as Mississippian(?) because of its position unconformably beneath Pennsylvanian conglomerate at Battle Mountain (Ferguson, Roberts, and Muller, 1952; Roberts, 1951). Cambrian fossils were later found in close proximity to the unusual feldspathic sandstone and became the most commonly assumed age (Hotz and Willden, 1964), although the Cambrian fossils have since 
been recognized to be part of a structurally disrupted upper Paleozoic section (Jones, 1991b; Jones, Wrucke, and others, 1978; McCollum and McCollum, 1991). Ordovician microfossils from the Harmony Formation in the Sonoma Range (MaddenMcGuire, Hutter, and Suczek, 1991) turned out to be unreliable as well. In 1994, a single Late Devonian Palmatolepis sp. conodont was recovered from a calcareous turbidite interbedded with the feldspathic sandstone in the Hot Springs Range (Jones, 1997a), and has remained the most convincing lower-age constraint thus far. Subsequent post-Ordovician conodont fragments also recovered from the Hot Springs Range have confirmed that the unit is clearly postOrdovician in age (Ketner, Crafford, and others, 2005). The Dutch Flat terrane crops out in Humboldt, Lander, and Pershing Counties. In the Hot Springs Range, it is structurally bounded to the northwest by the Golconda terrane and on the southeast by unit D€s of the Basin assemblage. In the Osgood Mountains, it has been structurally dismembered into mélange blocks that are part of an upper Paleozoic matrix of argillite and shale associated with the Golconda terrane (Jones, 1991b). In the Sonoma and East Ranges, much of it is mélange-like in character and has additionally been folded and faulted with Triassic and Ordovician rocks (Silberling, 1975). At Battle Mountain (Doebrich, 1994; Theodore, Murchey, and others, 1994), it is interpreted as faulted over adjacent rocks of the Basin assemblage (D€s), and is also unconformably overlain by the Pennsylvanian rocks of the Siliciclastic overlap assemblage, providing a critical constraint on the timing of its accretion to adjacent rocks. Because it is structurally bounded everywhere, its stratigraphic relation to other units in Nevada remains uncertain, although it has lithologic features in common with rocks of the Golconda terrane and the lower Paleozoic Basin assemblage (Ketner, Crafford, and others, 2005). In places it has west vergent folding throughout (Jones, 1993; Stahl, 1987), while in other places the formation is characterized by east vergent folding (Evans and Theodore, 1978). Interpretations of the origin of the rocks of the Harmony Formation and its tectonic history (Gehrels, Dickinson, and others, 2000; Ketner, Crafford, and others,
2005; Smith and Gehrels, 1994) have yet to fully explain its significant role in the midPaleozoic tectonism that affected Nevada. Its varied structural characteristics and enigmatic lithology suggest that this terrane is far traveled and has had a complex history of interaction with other Paleozoic rocks in Nevada

\section{Slope Assemblage}

The Slope assemblage rocks consist of limestone, argillaceous limestone, carbonaceous shale, calcareous siltstone, shale, argillite, quartzite, and bedded chert, with siliciclastic and conglomeratic horizons of chert clasts and quartz in places. The environment of deposition of this group of rocks is actually quite varied-in a number of cases the rocks are more typical of a "basin" environment. Slope facies rocks are difficult to identify because of their varied lithologic characteristics. These varied characteristics result from complex ocean chemistry variations through time, composition of rocks of adjacent margin(s), and tectonic setting of the margin. These factors all affect composition of sediment deposition along the slope of a continental margin through time. Nonetheless, a distinct group of rocks that was not deposited strictly in either a carbonate shelf environment or an ocean basin environment can clearly be identified in Nevada (Cook and Corboy, 2004). These rocks tend to be present in regions of naturally steep gradients along a margin, and thus do not commonly have the lateral extent that is seen in Carbonate shelf sequence rocks or Basin assemblage facies rocks. Many of these rocks are found today in structurally bounded sequences, but in a few important places, rocks of the Slope assemblage are tied depositionally to rocks of the Carbonate shelf sequence.

The slope of the margin was an important locus of disruption during mid-Paleozoic and later tectonism; these rocks were intimately involved in folding and thrusting of the margin during the Paleozoic and again during the Mesozoic. Many of these rocks are also compositionally ideal hosts for sediment-hosted gold deposits (Cook and Corboy, 2004) and have a known gold endowment of over 100 million ounces (Christensen, 1993), giving them global economic significance. In a number of cases, Slope assemblage rocks are not currently adequately distinguished at a regional map scale from Basin assemblage rocks. Three Slope assemblage rock units are designated on this map, and two other units with "slope" affinity are treated separately under the Nolan belt. Units MDst and DOts always occur in structurally bounded settings and cannot be tied to a specific place on the continental margin, except to say that they formed in proximity to a continental margin, or possibly on the slope of an oceanic feature such as a seamount. They contain significant horizons of siliciclastic material derived from a cratonal setting, and common turbiditic horizons suggesting significant sediment transport down a slope. Although units MDst and DOts are structurally bounded and have complex 
deformational histories involving imbricate thrusting, they usually contain definable stratigraphic sequences and important marker horizons (Cluer, Cellura, and others, 1997; Finney, Perry, and others, 1993; Noble, Cellura, and Cluer, 1999), and tend to be only locally altered or metamorphosed from mineralizing systems or igneous rocks. Unit DSt of the Slope assemblage is mapped as depositional on Ordovician and Silurian rocks of the Carbonate shelf sequence in a number of places, and is also involved in imbricate thrusting with Basin assemblage and Carbonate shelf sequence rocks. While great progress has been made in biostratigraphic dating of these rocks, in many areas further work is required to separate similar looking, different age rocks that have long been assumed to be part of a stratigraphic sequence, but are in fact structural imbrications of varied ages.

MDst Shale, graywacke, siltstone, chert, conglomerate, and limestone (Lower Mississippian and Devonian)-Carbonaceous shale, black chert and argillite, graywacke, chert-pebble conglomerate, and detrital limestone are the primary lithologies described from all of the rocks assigned to this unit, representing a mixed slope and basinal facies. On other maps these rocks have been included in a variety of units including the foreland basin and Devonian siliceous and transitional rocks. Mapping and new biostratigraphic data gathered in the last 30 years have shown that many of these rocks mapped only as Devonian also contain Early Mississippian fossils, thus making it difficult to distinguish them from known lithologically similar Lower Mississippian rocks. Although this unit is everywhere structurally bounded by faults, a stratigraphic link to older Slope assemblage rocks is possible. These rocks are imbricated with units $D € s$, PMcl, O€c, Ocq, DSt, Dc, and MDcl. Whether there is a definable continuous Early Mississippian through Devonian sequence within this unit is unknown, but is suggested in the Carlin-Piñon Range (Smith and Ketner, 1978). The Slaven Chert first described in the Shoshone Range (Gilluly and Gates, 1965) is black chert with carbonaceous shale beds 4-10 feet thick, limy brown-weathering sandstone as much as four ft thick with coarse fragments of chert, shale, greenstone, limestone, graywacke, feldspathic siltstone, and brown-weathering limestone 2-20 ft thick, and contains Late Devonian radiolarians (Boundy-Sanders, Sandberg, and others, 1999). The Mississippian Waterpipe Canyon Formation is a similar formation with basal medium-grained graywacke with interlayered black, carbonaceous shale; chert-pebble conglomerate; and bedded chert grading upward into sandstone layers with black, well-rounded quartz and a black, pyritic, phosphate- and baritebearing, argillaceous matrix interlayered with black, platy, quartz siltstone and finegrained graywacke interbeds. It contains Early Mississippian radiolarians (Peters, Armstrong, and others, 2003). In the HD Range in northeastern Elko County, an undated, light-gray weathering, brittle, black shale, structurally underlies the other thrust sheets and was referred to as the Chainman Shale by Riva (1970), but is included here in unit MDst. In the Windermere Hills a fissile black argillite with sporadic interbeds of quartz-chert arenite is poorly exposed with variable dips suggesting a complex structure (Oversby, 1972). In the Cockalorum Wash quadrangle along the Eureka-Nye County boundary, a pale yellow-brown, organic-detrital limestone contains quartz and chert grains locally interbedded with and succeeded upward by light-colored siliceous mudstone, claystone, and siltstone. The basal limestone contains mixed Mississippian and Devonian faunas; a thin chert from a higher zone has Osagean radiolarians (Hose, 1983). In the northern Adobe Range, this unit is recognized as dark siliceous rocks consisting of shale, argillite, and bedded chert. They are faulted and folded with sparse collections of Kinderhookian and Famennian radiolarians and conodonts (Ketner and Ross, 1990). The Webb Formation in the Carlin-Piñon Range is a gray siliceous mudstone with black to gray, tan-weathering, dense limestone in lenses near the top (Smith and Ketner, 1978). The argillite of Lee Canyon is a black siliceous argillite with a little black chert and very little conglomerate and sandstone near the top (Smith and Ketner, 1978). In the Sulphur Spring Range, the Bruffey sequence (Carlisle and Nelson, 1990) is a black chert pebble to boulder conglomerate and well-bedded gritty limestone, chert and limestone conglomerate, gray limy shale, and minor sandstone. Smith and Ketner (1978) describe the same rocks as gray limestone, sandy limestone, chert, and chert-pebble conglomerate. The Woodruff Formation from the same area is described by Carlisle and Nelson (1990) as a gray fissile shale, dolomitic siltstone, and black 
and brown bedded chert. Smith and Ketner (1978) describe the Woodruff as dark gray to black siliceous mudstone and chert, with lesser amounts of shale, siltstone, dolomitic siltstone, dolomite, and limestone. In the Shoshone Range, pale-red to palebrown weathering, platy, silty dolomite interbedded with black chert in the basal 50 $\mathrm{ft}$ of rocks referred to as the Pilot Shale by both Gilluly and Gates (1965) and Wrucke (1974) is included here. In the southern Independence Range, this unit consists of fine-grained limestone, bedded chert, shale, conglomerate, and prominent ledges of limy sandstone with Famennian and Frasnian (Late Devonian) conodonts (Ketner, 1998). In Welches Canyon northwest of Carlin, this unit is gray to black limestone, fine grained, and thin to thick bedded with common sandand silt-size clasts of quartz and chert grains. It also contains pebbles and cobbles of chert, and interlayered chert and siliceous shale as much as 50 feet thick (Evans, 1974). In the Snake Mountains, the unit is dark carbonaceous limestone apparently overlain by a light-gray, siliceous platy siltstone. Other outcrops that belong with unit MDst, but are not mapped separately on a regional scale from Slope or Basin assemblage units DEs and DOts include the Pinecone sequence in the Toquima Range (Coles and Snyder, 1985), and gold-bearing chert (Theodore, T., oral commun., 2006) mapped informally as the "Rodeo Creek Formation" (Peters, 1997b) in the Carlin area

Platy limestone, dolomite, and chert (Lower Devonian to Silurian)_Platy limestone, dolomite and chert are characteristic of the auriferous Roberts Mountains Formation in Nye, Elko, Eureka, and Lander Counties and of the Masket Shale and Gatecliff Formation in northern Nye County. This unit lies with depositional contact over the Hanson Creek Formation of unit SOc of the Carbonate shelf sequence (unit $\mathrm{O} €_{\mathrm{c}}$ in southern Nevada), and is also structurally imbricated with Carbonate shelf sequence rocks $(\mathrm{O} € \mathrm{c})$ and other Slope and Basin assemblages rocks (units D€s, DOts, MDst) across its area of exposure. In the Carlin area, rocks assigned to the Popovich Formation and the informal Bootstrap Limestone (Berger and Theodore, 2005; Jory, 2002) are also included. In the Monitor Range, the Roberts Mountains, and the Sulphur Spring Range, unit DSt is mapped as stratigraphically overlain by unit DSc. To what extent this "overlying" dolomite is truly a stratigraphic unit as opposed to an alteration product of this unit (Nichols and Silberling, 1977a) is unclear. A stratigraphic contact with unit MDst in the Carlin area is possible based on recent mapping (Berger and Theodore, 2005; Theodore, Moring, and others, 2003)

Calcareous shale, siltstone, chert, quartzite, and greenstone (Devonian to Ordovician)Calcareous shale, siltstone, sandstone, chert, quartzite, and greenstone in the Vinini Formation in Lander, Eureka, Elko, and northern Nye Counties, and the Clipper Canyon Group in the northern Toquima Range are the core rocks of unit DOts. Difficulties in identifying distinct paleogeographic settings within Ordovician slope facies rocks are discussed in Finney and Perry (1991) and Finney and others (1993). On a regional scale, the distinction between this unit and rocks traditionally mapped as the Valmy Formation (D€s) is the preponderance of shale and siltstone of cratonal derivation that is present in the Vinini rocks but less common in the Valmy rocks. Both rock units contain bedded chert, massive quartzite, and greenstone (Finney and Perry, 1991) in many places. Many lower Paleozoic rocks grouped here likely formed in a basinal rather than slope setting, but the presence of more common siliciclastic horizons of shale, siltstone, and sandstone distinguish them as a regional grouping from the lower Paleozoic Basin assemblage rocks. Whether this is a function of distinct paleogeographic settings of coeval units as interpreted by early workers, or is actually an age distinction of older (Valmy) versus younger (Vinini) Ordovician rocks, as suggested more recently for at least the Roberts Mountains (Finney, Perry, and others, 1993), remains to be determined on a regional scale. Originally thought to be primarily Ordovician, studies and biostratigraphic data have demonstrated that this unit consists of tightly imbricated Devonian, Silurian, and Ordovician rocks (Coles and Snyder, 1985; Noble and Finney, 1999). The distinction between units DOts and DEs as currently mapped on a regional scale is ambiguous in many places. Identifying the numerous occurrences of Devonian and Silurian rocks that are embedded within this unit on a regional scale would significantly enhance our 
understanding of the complex structural history of these rocks. These rocks are everywhere in structural contact with other Paleozoic rocks including units $\mathrm{PMcl}$, Pacl, Dc, MDst, DSt, DSc, and Dcd. Stratigraphic correlation has been made between rocks of the Vinini Formation and the Carbonate shelf sequence in Nevada (Finney and Perry, 1991) on the basis of occurrence of quartzite that is coeval with the shelf unit Ocq. While this does suggest a connection between the Ordovician rocks of this composite unit and North America, the quartzite was deposited along a 1,000-mile length of the margin (Ketner, 1986) and thus does not constrain the rocks of unit DOts to deposition along a specific section of the margin. These rocks are unconformably overlain sporadically by units $\mathrm{Pacl}$ and $\mathrm{PPacl}$, and post-Paleozoic cover rocks

\section{Basin Assemblage}

Basin assemblage rocks range from latest Cambrian through Devonian in age and represent rocks that formed primarily in a basin or lower continental-slope setting. Common rock types include chert, argillite, feldspathic siltstone and shale, quartzite, greenstone, and minor carbonate. Because of complex deformation in all of these rocks, it has been difficult to subdivide them into Ordovician, Silurian, and Devonian units, and they have generally been grouped together into larger units that represent a wide range of age and lithologic characteristics on regional maps. Distinguishing the numerous occurrences of Ordovician, Silurian, and Devonian rocks that are embedded within this unit on a regional scale would significantly enhance our understanding of the complex structural history of these rocks. These rocks are all displaced from their place of origin, and the amount of displacement relative to the continental margin is unknown, although in every place that structural studies have been done, these rocks show evidence of regional east-directed transport (Evans and Theodore, 1978; Oldow, 1984b; Peters, 1997a, b, c). Thick beds of massive quartzite are common and the timing of their deposition corresponds to at least some of the influx of quartz sand along the continental shelf suggesting a connection to the North American craton in places (Miller and Larue, 1983). Quartz sand was deposited along much of the western margin of North America more than once during the Ordovician (Finney and Perry, 1991; Gehrels, Dickinson, and others, 2000; Ketner, 1986). The Basin assemblage may consist of several distinct terranes, but regional mapping can't yet clearly distinguish them.

\section{DEs Shale, chert, quartzite, greenstone, and limestone} (Devonian to Upper Cambrian)_Includes the Valmy Formation in Eureka, Humboldt, Lander, and Pershing Counties; Devonian to Upper Cambrian mudstone, shale, chert, siltstone, and gray quartzite in Elko County (Leslie, Isaacson, and others, 1991); Devonian to Ordovician slate, chert, limestone, and sandstone in Mineral County; Devonian to Upper Cambrian rocks in Eureka County (Finney, Perry, and others, 1993); some rocks originally mapped as the Palmetto Formation in Esmeralda County (Albers and Stewart, 1972; Ferguson and Cathcart, 1954); and the Sonoma Range Formation (Ferguson, Muller, and Roberts, 1951) in the Sonoma Range in Humboldt County (later included with the Valmy Formation). The distinctions between these rocks and rocks of the Slope assemblage (DOts) are (1) a more complex and varied history of deformation; (2) less well-defined internal stratigraphic characteristics, which may be a function of structural complexity; (3) fewer shale, siltstone, and sandstone interbeds; (4) less carbonate; and (5) in the Roberts Mountains at least, the Ordovician rocks of this unit are older than the Slope assemblage Ordovician rocks. Like unit DOts, no basement is preserved with these rocks, making it difficult to determine where they were originally laid down, and how far they have been transported. This unit includes Devonian, Silurian, Ordovician, and uppermost Cambrian rocks imbricately faulted and folded together. In a few places, Silurian rocks are defined regionally and broken out separately (Ss), but for the most part they are included in this unit. Likewise, significant exposures of Devonian rocks have been included in unit MDst, but many more are not differentiated from this unit. A great variety of depositional settings are present in ocean basins, and this diversity is represented in these rocks (Watkins and Browne, 1989). While these rocks share a common deformation history indicative of east-directed transport from folding and thrusting along regional structures in different areas of Nevada, these rocks have been subject to additional distinct tectonic events during the Mesozoic and the Paleozoic resulting in significant spatial variability in the structure of these rocks (Evans and Theodore, 1978; Oldow, 1984b)

Feldspathic sandstone, siltstone, shale, and chert (Silurian)—In the HD Range in northeastern Elko County, the Noh Formation was described by Riva (1970) and consists of a basal, dark-gray chert and light-gray shale, light-brown weathering, 
siliceous and tuffaceous siltstone and shale, and tan- and light-brown-weathering, thinbedded siltstone, sandstone, and minor shale. It contains a large and diagnostic Wenlockian (Early Silurian) graptolite fauna, and is partly coeval with the base of the Roberts Mountains Formation (DSt) which also has a conspicuous basal chert ledge. The similar age Elder Sandstone in Lander and Eureka Counties was named for moderately cemented sandstones exposed in the Shoshone Range (Gilluly and Gates, 1965). It is primarily a fine-grained, silty sandstone, sandy siliceous and tuffaceous shale, and thin, platy, light brown chert. Much of the sandstone and siltstone is notably feldspathic, including abundant angular fragments of potassium feldspar, and has reportedly interbedded rhyolite in places (Theodore, T., oral commun., 2006). It is grouped with unit $D € s$ or DOts in many places. Its unusual lithologic characteristics warrant a separate grouping where it can be separated from these units (Noble, Finney, and Cluer, 2000). Zircon studies have suggested that the feldspathic source material for these rocks was not located adjacent to the Nevada part of the continental margin, but is derived from a source either farther to the north or in Mexico (Gehrels, Dickinson, and others, 2000). Likewise, tuffaceous source material for the shale described in the Noh Formation is not known from the Nevada continental margin of this time. Like most other rocks of the Slope and Basin assemblages, unit Ss is everywhere in structural contact with other Paleozoic rocks. It is structurally imbricated with units D€s, DOts, and MDst. Whether these rocks have traveled a significant distance either toward or along the margin as discrete tectonic blocks or as sediment transported in offshore turbidity systems is not known, but no basement is preserved with them, and they are unconformably overlain by the Pennsylvanian and younger Siliciclastic overlap assemblage

\section{Nolan Belt}

A belt of lower Paleozoic rocks with strong affinity to the North American continental margin but with unusual structural characteristics form a discrete belt west and northwest of displaced rocks of the Slope and Basin assemblages. Earlier maps included these rocks in either "Transitional" or
"Siliceous" groupings (Roberts, Hotz, and others, 1958). They are different from the other Paleozoic rocks in a number of important ways that warrant distinction as a separate group. These rocks have structural characteristics of an accreted terrane, that is, they exhibit polyphase deformation, but have stratigraphic ties to North America that suggest they have not traveled great distances laterally from the continental margin. The origin of the name of this group is for T.B. Nolan, whose early paper defined many of these rocks as part of an important "geanticline" during the later Paleozoic long before such concepts had any grounding in modern tectonic understanding (Nolan, 1928), and prior to recognition of the magnitude of displacement that has affected adjacent Paleozoic rocks and terranes.

The distinguishing characteristics of the Nolan belt of rocks are (1) lithologically they define a region of outer shelf and slope Cambrian and Ordovician rocks, originally deposited in a more proximal position to the Carbonate shelf sequence than the rocks of units DEs or DOts, which now lie east, or inboard of many exposures of units O€td and €td, (2) unlike rocks of units DOts, D€s or Ss, they are stratigraphically attached to their Cambrian to Precambrian quartzite basement ( $€ Z q)$, otherwise exposed only much farther to the east, (3) they have a varied and complex structural history that in at least some cases clearly involves multiple pre-Pennsylvanian deformation events with both eastvergent and west-vergent deformation (Crafford and Grauch, 2002; Ehman, 1985; Means, 1962; Oldow, 1984b), (4) like rocks of the Basin, Slope, and Foreland basin assemblages, they are unconformably overlain by Pennsylvanian and younger rocks of the Siliciclastic overlap assemblage, constraining the age of much of their deformation to preMiddle Pennsylvanian, and (5) rocks of the Nolan belt have been much more deeply buried than coeval and lithologically similar rocks that crop out farther east, as witnessed by the metamorphic character of the slates, phyllites, and schists, and by the Conodont Color Alteration Index of the rocks (Crafford and Harris, 2005). Two units are included in this group, units O€td, and $€ t d$. The basement rocks are treated separately because they are common to the base of both the Nolan belt and the Carbonate shelf sequence.

\section{O€td Shale, chert, phyllite, quartzite, and limestone (Ordovician to Cambrian)—Rocks included in this unit have been mapped as the Broad Canyon Formation and Crane Canyon sequence in Lander County (Means, 1962), the Palmetto Formation in Esmeralda and Nye Counties (Ferguson and Cathcart, 1954), the Van Duzer Limestone in northern Elko County (Coats, 1971; Coats, Howard, and Greene, 1984; Decker, 1962; Ehman, 1985), and many other unnamed and locally named rocks. These rocks are strongly deformed, although the nature of the deformation is variable across the belt (Oldow, 1984b) and not well understood}


regionally. This unit is usually shown both in fault contact with adjacent units $€$ td and $€ Z q$ and gradational with them. Unit Pacl of the Siliciclastic overlap assemblage is shown unconformably deposited on this unit in Wall Canyon of the Toiyabe Range in Nye County. In a few cases, this unit is a stratigraphic continuation from $€ \mathrm{td}$, but in most places it represents undifferentiated rocks of both Ordovician and Cambrian age that overlap with $€ \mathrm{td}$, or whose age is poorly constrained

€td Phyllite, schist, shale, thin-bedded limestone, chert, and siltstone (Cambrian)—Shale, thin-bedded limestone, phyllite, hornfels, quartzite, chert, and siltstone are typical of this Cambrian unit which exhibits regional metamorphism suggesting significant burial depths have heated and recrystallized many of these rocks. This unit includes rocks mapped informally as the Bull Run Dolomite and Edgemont Formation in northern Elko County by Ehman (1985); the Crane Canyon sequence in the Toiyabe Range; some regions mapped as Dunderberg Shale; and the Swarbrick Formation in northern Nye County, the Emigrant Formation in southern Nye and Esmeralda Counties, the Mule Spring Limestone in Esmeralda County, the Preble Formation in Humboldt and Pershing Counties (MaddenMcGuire, 1991), the Paradise Valley Chert in Humboldt County, and the Schwin Formation (Gilluly and Gates, 1965) in the Shoshone Range in Lander County. In most exposures this unit lies transitionally above the Cambrian-Precambrian quartzite unit $€ Z q$. In places this unit is transitional into O€td. This unit is also in structural contact with D€s, DOts, O€c, O€td, €Zq, the Golconda terrane (GC), and the Dutch Flat terrane (DF). In the Osgood Mountains (Boskie and Schweickert, 2001; Crafford and Grauch, 2002; Madden-McGuire and Marsh, 1991), the Bull Run Mountains (Ehman, 1985), the Toiyabe Range (Means, 1962), and the Miller Mountain area (Oldow, 1984b) these rocks exhibit complex polyphase deformation with a strong westvergent component. At Edna Mountain near Golconda in Humboldt County, these rocks are unconformably overlain by both Pacl and PPacl of the Siliciclastic overlap assemblage

\section{Precambrian And Other Rocks}

\section{Lower Cambrian to Latest Proterozoic Clastic Rocks}

Precambrian to Lower Cambrian clastic rocks form the base of the Carbonate shelf sequence in eastern and southern Nevada. They also form the stratigraphic base of the rocks of the Nolan belt. They are part of a large sequence of Precambrian rocks that represent the original rifted margin of western North America (Stewart, 1972). They rest unconformably over older Proterozoic basement that is only exposed in southernmost Nevada.

\begin{tabular}{|c|c|}
\hline$€ Z q$ & $\begin{array}{l}\text { Crossbedded quartzite, siltstone, and phyllite } \\
\text { (Lower Cambrian and latest Protero- } \\
\text { zoic)-These lowermost Cambrian to } \\
\text { Precambrian strata are scattered over much } \\
\text { of central and eastern Nevada and form the } \\
\text { base of the Phanerozoic part of the conti- } \\
\text { nental margin stratigraphic section. They } \\
\text { include the Campito, Deep Spring, Hark- } \\
\text { less, and Poleta Formations, and the Reed } \\
\text { Dolomite in Esmeralda County; the Gold } \\
\text { Hill Formation in northern Nye County; } \\
\text { unnamed quartzite and shale in White Pine } \\
\text { County; the Osgood Mountain quartzite in } \\
\text { Humboldt County; the Prospect Mountain } \\
\text { Quartzite in northern Nye, Lincoln, Eureka, } \\
\text { and Elko Counties; unnamed quartzite and } \\
\text { shale in Lander and Clark counties; and the } \\
\text { Stirling Quartzite, Wood Canyon Formation, } \\
\text { and Zabriskie Quartzite in southern Nye } \\
\text { County. In a number of places, these rocks } \\
\text { are depositional on Late Proterozoic unit } \\
\text { Zqs. In southernmost Clark County, } € Z q \\
\text { is lying unconformably directly on Early } \\
\text { Proterozoic gneiss (Xm). In the east-central } \\
\text { part of Nevada, } € Z q \text { is overlain deposition- } \\
\text { ally by Cambrian carbonate ( } € c \text { ) of the } \\
\text { Carbonate shelf sequence. In the Nolan belt, } \\
\text { these rocks are depositionally overlain by } \\
\text { unit } € \text { td. In the Osgood Mountains in Hum- } \\
\text { boldt County, Permian and Pennsylvanian } \\
\text { rocks of the Siliciclastic overlap assemblage } \\
\text { (PPacl, Pacl) rest unconformably directly } \\
\text { on the Osgood Mountain Quartzite }\end{array}$ \\
\hline
\end{tabular}

€Zqm Metaquartzite (Lower Cambrian and latest Proterozoic)_-This highly metamorphosed equivalent of $€ Z q$ crops out in the Ruby Mountains and East Humboldt Range in Elko County, in the Toquima and Monitor Ranges in northern Nye County, and at the northern tip of the White Mountains in Mineral and Esmeralda Counties. In the Ruby Mountains it is transitional into 
O $€ \mathrm{~cm}$, and in the White Mountains it is transitional into O€td

Zqs

Quartzite, siltstone, conglomerate, limestone, and dolomite (Late Proterozoic)—Limestone, quartzite, dolomite, siltstone, conglomerate, and metamorphic rocks crop out in the southeastern, east-central, and northeastern regions of the State as part of Zqs. It forms the Proterozoic base of the continental margin stratigraphic section. This unit includes the Johnnie Formation in southern Nye and Lincoln Counties, schist in Elko County, the McCoy Creek Group metamorphic rocks in Elko and White Pine Counties, and the Wyman Formation in Esmeralda and southern Nye Counties. This rock is overlain by $€ Z q$. Its base is not exposed

\section{Proterozoic Basement Rocks}

Yfi Felsic phaneritic intrusive rocks (Middle Proterozoic)—This porphyritic rapakivi granite is present only in Clark County where it intrudes Proterozoic gneiss and schist $(\mathrm{Xm})$

Xm Gneiss and schist (Early Proterozoic)—Exposed mostly in Clark and Lincoln Counties, with two small outliers in southern Nye County

\section{Other Rocks}

Other rocks include a breccia unit of mixed breccias that identifies locally disrupted rocks; a gneiss, schist, and migmatite in Elko County, the only high-grade metamorphic rock in Nevada; and ultramafic rocks with serpentine that are scattered in a few places around the State adjacent to major Paleozoic and Mesozoic terrane boundaries.

br Mixed breccias including volcanic, thrust, jasperoid, and landslide megabreccia (Tertiary to Jurassic)—Breccias of various origins are scattered across Clark, Nye, Lincoln, Elko, Eureka, Lander, and White Pine Counties. Most are interpreted to be Tertiary in age, but have tectonic, volcanic, and metamorphic origins, and include jasperoids, brecciated tuffs, exotic slide blocks, landslide deposits, megabreccia, thrust breccia, and debris beds

TAgn Metamorphic-igneous complex (Oligocene, Cretaceous, and Jurassic with Paleozoic, Proterozoic, and Archean
protolith)-In the Ruby Mountains and East Humboldt Range in Elko County, this unit is an orthogneiss with amphibolite and paragneiss. It includes granodiorite and quartz monzonite gneiss, granitic to dioritic gneiss, biotite and muscovite schist, quartzitic schist, quartzite, calcsilicate rocks, marble, migmatitic Oligocene granodiorite, and Cretaceous and Jurassic granite. The protoliths for the East Humboldt Range orthogneiss include Archean through Paleozoic rocks (Lush, McGrew, and others, 1988; McGrew, Peters, and Wright, 2000)

KPsp Ultramafic rocks and serpentine (Triassic or upper Paleozoic)—Ultramafic rocks are present in very small belts or lenses in a few places across the State. In the Candelaria Hills along the Mineral-Esmeralda County boundary, they crop out in a thrust complex that overlies the Candelaria Formation ( $\mathrm{kcl})$. At Willow Spring, at the southern end of the Toquima Range south of Manhattan, serpentine is exposed again adjacent to the Candelaria Formation and deformed lower Paleozoic rocks (O€td). A few small outcrops also are present on the east side of the Toquima Range near Belmont adjacent to lower Paleozoic rocks. In the Toiyabe Range in Nye County, scattered outcrops of serpentine form a narrow north-south trending belt adjacent to the Golconda terrane (GC), deformed lower Paleozoic rocks (O€td, €td), and the Siliciclastic overlap assemblage. An early Triassic conodont was recovered near the serpentine near Marysville Canyon (Poole and Wardlaw, 1978), although the Candelaria Formation does not show on the map in this area. All of these exposures of ultramafic rocks are in a similar relative tectonic position above deformed lower Paleozoic rocks and the Siliciclastic overlap assemblage, and below the structurally overlying Golconda terrane. A narrow belt of serpentine and gabbro is exposed at the northern edge of the Golconda terrane in the Hot Springs Range in Humboldt County. In this case, the ultramafic rock is structurally above the Golconda terrane, and beneath the overlying Mesozoic Jungo terrane (JO) 


\section{Map References}

References used in editing the geologic map in addition to the 1978 State map and the individual county maps are shown in the "Refs" attribute column of the geology layer. The codes and references used are listed here and shown in complete form in the references section.

\begin{tabular}{|c|c|}
\hline Map reference code & Reference \\
\hline Abase & $\begin{array}{l}\text { Henry, Chris, unpublished radiometric database of Nevada, } \\
\text { Nevada Bureau of Mines and Geology }\end{array}$ \\
\hline Barnes and others, 2001 & Barnes, Burton, and others, 2001 \\
\hline Cohen, 1980 & Cohen, 1980 \\
\hline CONO & Harris, Anita, ConodontSamples.shp, this map \\
\hline Ehman, 1985 & Ehman, 1985 \\
\hline GSA SP 163 & Silberling, 1975 \\
\hline Heidrick, 1965 & Heidrick, 1965 \\
\hline Lovejoy, GSA Bull 70, p. 539 & Lovejoy, 1959 \\
\hline Means, 1962 & Means, 1962 \\
\hline Miller and others, 1984 & Miller, Holdsworth, and others, 1984 \\
\hline NBMG FS Map 12 & Henry, 1996 \\
\hline NBMG FS Map 14 & Jones, 1997b \\
\hline NBMG FS Map 21 & Miller, Gans, and others, 1999 \\
\hline NBMG FS Map 4 & Mueller, 1993 \\
\hline NBMG Map 104 & Martin and Naumann, 1995 \\
\hline NBMG Map 143 & Theodore, Moring, and others, 2003 \\
\hline NBMG Map 35 & Fritz, 1968 \\
\hline NBMG Map 97 & Carlisle and Nelson, 1990 \\
\hline NBMG OFR 03-4 & Thorman, Brooks, and others, 2003 \\
\hline NBMG OFR 04-9 & Thompson, Teal, and Meeuwig, 2002 \\
\hline Neff, 1969 & Neff, 1969 \\
\hline Oldow, 1984 & Oldow, 1984a \\
\hline OSS, 1993 & Oldow, Satterfield, and Silberling, 1993 \\
\hline Oversby, 1972 & Oversby, 1972 \\
\hline PandW, 1978 & Poole and Wardlaw, 1978 \\
\hline Peters and others, 2003 & Peters, Armstrong, and others, 2003 \\
\hline Riva, 1970 & Riva, 1970 \\
\hline Rowley, 1980 & Rowley, 1980 \\
\hline SandS, 1989 & Speed, Silberling, and others, 1989 \\
\hline Sayeed, 1973 & Sayeed, 1973 \\
\hline Speed-Diablo-77 & Speed, MacMillan, and others, 1977 \\
\hline Stewart, 1980 & Stewart, 1980 \\
\hline Thurber, 1982 & Thurber, 1982 \\
\hline USGS B 1162-B & Ketner and Smith, 1963 \\
\hline USGS B 1312-P & Wells and Elliott, 1971 \\
\hline USGS B 1439 & Coats, Green, and others, 1977 \\
\hline USGS B 1988-D & Ketner, Murchey, and others, 1993 \\
\hline USGS GQ-1117 & Evans, 1974 \\
\hline USGS GQ-1174 & Erickson and Marsh, 1974a \\
\hline USGS GQ-1307 & McKee, 1976a \\
\hline USGS GQ-1710 & John and Silberling, 1994 \\
\hline USGS GQ-1721 & Anderson and Hintze, 1993 \\
\hline USGS GQ-1758 & Miller, Grier, and Brown, 1995 \\
\hline USGS GQ-1759 & Hintze and Axen, 1995 \\
\hline USGS GQ-656 & Gilluly, 1967 \\
\hline USGS I-1028 & Smith and Ketner, 1978 \\
\hline
\end{tabular}




\begin{tabular}{|ll|}
\hline Map reference code & Reference \\
\hline USGS I-1410 & Hose, 1983 \\
USGS I-1578 & Ekren and Byers, 1985 \\
USGS I-1866 & Loucks, Tingey, and others, 1989 \\
USGS I-1902 & Ketner and Evans, 1988 \\
USGS I-2081 & Ketner and Ross, 1990 \\
USGS I-2082 & Ketner, 1990 \\
USGS I-2097 & Smith, Ketner, and others, 1990 \\
USGS I-2394 & Wallace, 1993 \\
USGS I-2409 & Whitebread, 1994 \\
USGS I-2629 & Ketner, 1998 \\
USGS I-612 & Nolan, Merriam, and Brew, 1971 \\
USGS I-667 & Evans and Ketner, 1971 \\
USGS I-793 & Nolan, Merriam, and Blake, 1974 \\
USGS MF-1877-J & John, 1987 \\
USGS MF-2062 & Silberling and John, 1989 \\
USGS MF-2154-A & Greene, Stewart, and others, 1991 \\
USGS MF-2327 & Shawe, 2002 \\
USGS OFR 03-236 & Sloan, Henry, and others, 2003 \\
USGS OFR 68-260 & Stewart and McKee, 1968 \\
USGS OFR 84-644 & Coats, Howard, and Greene, 1984 \\
USGS OFR 91-429 & Theodore, 1991 \\
USGS OFR 94-664 & Doebrich, 1994 \\
USGS PP 575-D, p. 56-63 & Stewart and Palmer, 1967 \\
USGS PP 592 & Silberling and Wallace, 1969 \\
USGS PP 668 & Lee and Van Loenen, 1971 \\
USGS PP 931 & McKee, 1976b \\
USGS SI-2814 & Page, Lundstrom, and others, 2005 \\
Wyld, 2002 & Wyld, 2002 \\
\hline
\end{tabular}

\section{References}

Albers, J.P., and Stewart, J.H., 1972, Geology and mineral deposits of Esmeralda County, Nevada: Nevada Bureau of Mines and Geology Bulletin 78, 80 p.

Anderson, R.E., and Hintze, L.F., 1993, Geologic map of the Dodge Spring quadrangle, Washington County, Utah, and Lincoln County, Nevada: U.S. Geological Survey Geologic Quadrangle Map GQ-1721, scale 1:24,000.

Archbold, N.L., and Paul, R.R., 1970, Geology and mineral deposits of the Pamlico Mining District, Mineral County, Nevada: Nevada Bureau of Mines Bulletin 74, 12 p.

Barnes, C.G., Burton, B.R., Burling, T.C., Wright, J.E., and Karlsson, H.R., 2001, Petrology and geochemistry of the Harrison Pass pluton, Ruby Mountains core complex, northeastern Nevada: Journal of Petrology, v. 42, p. 901-929.

Berger, V.I., and Theodore, T.G., 2005, Implications of stratabound Carlin-type gold deposits in Paleozoic rocks of north-central Nevada, in Rhoden, H.N., Steiniger, R.C., and Vikre, P.G., eds., Geological Society of Nevada Symposium 2005: Window to the World: Reno, Nev., Proceedings, v. 1, p. $43-78$.

Bliss, J.D., ed., 1992, Developments in mineral deposit modeling: U.S. Geological Survey Bulletin 2004, 168 p.

Blome, C.D., and Reed, K.M., 1995, Radiolarian biostratigraphy of the Quinn River Formation, Black Rock terrane, north-central Nevada: Correlations with eastern Klamath terrane geology: micropaleontology, v. 41, no. 1, p. 49-68.

Bonham, H.F.J., and Papke, K.G., 1969, Geology and mineral deposits of Washoe and Storey Counties, Nevada: Nevada Bureau of Mines and Geology Bulletin 70, 140 p. 
Boskie, R.M., and Schweickert, R.A., 2001, Structure and stratigraphy of Lower Paleozoic rocks of the Getchell Trend, Osgood Mountains, Humboldt County, Nevada, in Shaddrick, D.R., Zbinden, E., Mathewson, D.C., and Prenn, C., eds., Regional tectonics and structural control of ore: The major gold trends of northern Nevada: Reno, Nev., Geological Society of Nevada Special Publication No. 33, p. 263-293.

Boundy-Sanders, S.Q., Sandberg, C.A., Murchey, B.L., and Harris, A.G., 1999, A late Frasnian (Late Devonian) radiolarian, sponge spicule, and conodont fauna from the Slaven Chert, northern Shoshone Range, Roberts Mountains allochthon, Nevada: micropaleontology, v. 45, no. 1, p. 62-68.

Brueckner, H.K., and Snyder, W.S., 1985, Structure of the Havallah sequence, Golconda allochthon, Nevada: Evidence for prolonged evolution in an accretionary prism: Geological Society of America Bulletin, v. 96, no. 9, p. 1113-1130.

Burke, D.B., and Silberling, N.J., 1973, The Auld Lang Syne Group of Late Triassic and Jurassic(?) age, North-Central Nevada: U.S. Geological Survey Bulletin 1394-E, 14 p.

Carlisle, D., and Nelson, C.A., 1990, Geologic map of the Mineral Hill quadrangle, Nevada: Nevada Bureau of Mines and Geology Map 97, scale 1:48,000.

Christensen, O.D., 1993, Carlin Trend geologic overview, in Christensen, O.D., ed., Gold deposits of the Carlin Trend, Nevada: Boulder, Colo., Society of Economic Geologists Guidebook Series No. 18, p. 12-26.

Cluer, J.K., Cellura, B.R., Keith, S.B., Finney, S.C., and Bellert, S.J., 1997, Stratigraphy and structure of the Bell Creek Nappe (Antler Orogen), Ren Property, northern Carlin Trend, Nevada, in Perry, A.J., and Abbott, E.W., eds., The Roberts Mountains Thrust, Elko and Eureka Counties, Nevada: Reno, Nevada Petroleum Society Field Trip Guidebook, p. 41-54.

Coats, R.R., 1971, Geologic map of the Owyhee quadrangle, Nevada-Idaho: U.S. Geological Survey Miscellaneous Geologic Investigations Map I-665, scale 1:48,000.

Coats, R.R., 1987, Geology of Elko County, Nevada: Nevada Bureau of Mines and Geology Bulletin 101, 112 p.

Coats, R.R., Green, R.C., Cress, L.D., and Marks, L.Y., 1977, Mineral resources of the Jarbidge Wilderness and adjacent areas, Elko County, Nevada: U.S. Geological Survey Bulletin 1439, 79 p.

Coats, R.R., Howard, K.A., and Greene, R.C., 1984, Geologic map of the southeast quarter of the Mountain City quadrangle, Elko County, Nevada: U.S. Geological Survey Open-File Report 84-644, scale 1:20,000.
Cohen, D.K., 1980, The geology and petrography of the Millet Ranch plutons: A mixed magma: Reno, Nev., University of Nevada, Mackay School of Mines, Masters thesis, 62 p.

Coles, K.S., and Snyder, W.S., 1985, Significance of lower and middle Paleozoic phosphatic chert in the Toquima Range, central Nevada: Geology, v. 13, no. 8, p. 573-576.

Compton, R.R., 1960, Contact metamorphism in Santa Rosa Range, Nevada: Bulletin of the Geological Society of America, v. 71, p. 1383-1416.

Cook, H.E., and Corboy, J.J., 2004, Great Basin Paleozoic carbonate platform: Facies, facies transitions, depositional models, platform architecture, sequence stratigraphy, and predictive mineral host models: U.S. Geological Survey Open-File Report 2004-1078, 129 p.

Cornwall, H.R., 1972, Geology and mineral deposits of Southern Nye County, Nevada: Nevada Bureau of Mines and Geology Bulletin 77, 49 p.

Cox, D.P., and Singer, D.A., eds., 1992, Mineral deposit models: U.S. Geological Survey Bulletin 1693, 379 p.

Crafford, A.E.J., and Grauch, V.J.S., 2002, Geologic and geophysical evidence for the influence of deep crustal structures on Paleozoic tectonics and the alignment of world-class gold deposits, north-central Nevada, USA: Ore Geology Reviews, v. 21, p. 157-184.

Crafford, A.E.J., and Harris, A.G., 2005, New digital conodont Color Alteration Index (CAI) maps of Nevada: Geological Society of America Abstracts with Programs, v. 37, no. 7, p. 379.

Decker, R.W., 1962, Geology of the Bull Run quadrangle, Elko County, Nevada: Nevada Bureau of Mines Bulletin 60, $61 \mathrm{p}$.

Dilek, Y., and Moores, E.M., 1995, Geology of the Humboldt igneous complex, Nevada, and tectonic implications for the Jurassic magmatism in the Cordilleran orogen, in Miller, D.M., and Busby, C., eds., Jurassic magmatism and tectonics of the North American Cordillera: Boulder, Colo., Geological Society of America Special Paper 299, R.L. Armstrong Memorial Volume, p. 229-248.

Doebrich, J.L., 1994, Preliminary geologic map of the Galena Canyon quadrangle, Lander County, Nevada: U.S. Geological Survey Open-File Report 94-664, scale 1:24,000.

Dott, R.H., Jr, 1955, Pennsylvanian stratigraphy of Elko and northern Diamond Ranges, northeastern Nevada: Bulletin of the American Association of Petroleum Geologists, v. 39, no. 11 , p. 2211-2305.

du Bray, E.A., and Crafford, A.E.J., 2007, Modal composition and age of intrusions in north-central and northeast Nevada: U.S. Geological Survey Data Series 250, CD-ROM, 16 p. 
Ehman, K.D., 1985, Paleozoic stratigraphy and tectonics of the Bull Run Mountains, Elko County, northern Nevada: Davis, University of California, Department of Geology, Ph.D. dissertation, $174 \mathrm{p}$.

Ekren, E.B., and Byers, F.M., Jr., 1985, Geologic map of the Win Wan Flat, Kinkaid NW, Kinkaid, and Indian Head Peak quadrangles, Mineral County, Nevada: U.S. Geological Survey Miscellaneous Investigations Series Map I-1578, scale 1:48,000.

Erickson, R.L., and Marsh, S.P., 1974a, Geologic map of the Golconda quadrangle, Humboldt County, Nevada: U.S. Geological Survey Geologic Quadrangle Map GQ-1174, scale 1:24,000.

Erickson, R.L., and Marsh, S.P., 1974b, Geologic map of the Iron Point quadrangle, Humboldt County, Nevada: U.S. Geological Survey Geologic Quadrangle Map GQ-1175, scale 1:24,000.

Evans, J.G., 1974, Geologic map of the Welches Canyon quadrangle, Eureka County, Nevada: U.S. Geological Survey Geologic Quadrangle Map GQ-1117, scale 1:24,000.

Evans, J.G., and Ketner, K.B., 1971, Geologic map of the Swales Mountain quadrangle and part of the Adobe Summit quadrangle, Elko County, Nevada: U.S. Geological Survey Miscellaneous Geologic Investigations Map I-667, scale 1:24,000.

Evans, J.G., and Theodore, T.G., 1978, Deformation of the Roberts Mountains allochthon in North-Central Nevada: U.S. Geological Survey Professional Paper 1060, 18 p.

Ferguson, H.G., and Cathcart, S.H., 1954, Geology of the Round Mountain quadrangle, Nevada: U.S. Geological Survey Geologic Quadrangle Map GQ-40, scale 1:125,000.

Ferguson, H.G., Muller, S.W., and Cathcart, S.H., 1954, Geologic map of the Mina quadrangle, Nevada: U.S. Geological Survey Geologic Quadrangle Map GQ-45, scale $1: 125,000$.

Ferguson, H.G., Muller, S.W., and Roberts, R.J., 1951, Geology of the Winnemucca quadrangle, Nevada: U.S. Geological Survey Geologic Quadrangle Map GQ-11, scale $1: 125,000$.

Ferguson, H.G., Roberts, R.J., and Muller, S.W., 1952, Geology of the Golconda quadrangle, Nevada: U.S. Geological Survey Geologic Quadrangle Map GQ-15, scale $1: 125,000$.

Finney, S.C., and Perry, B.D., 1991, Depositional setting and paleogeography of Ordovician Vinini Formation, central Nevada, in Cooper, J.D., and Stevens, C.H., eds., Paleozoic paleogeography of the Western United States-II: Los
Angeles, Calif., Society of Economic Paleontologists and Mineralogists, Pacific Section, v. 2, p. 747-766.

Finney, S.C., Perry, B.D., Emsbo, P., and Madrid, R.J., 1993, Stratigraphy of the Roberts Mountains allochthon, Roberts Mountains and Shoshone Range, Nevada, in Lahren, M.M., Trexler, J.H., Jr., and Spinosa, C., eds., Crustal evolution of the Great Basin and Sierra Nevada: Department of Geological Sciences, University of Nevada, Reno, Cordilleran/ Rocky Mountain Section, Geological Society of America Guidebook, p. 197-230.

Fouch, T.D., Hanley, J.H., and Forester, R.M., 1979, Preliminary correlation of Cretaceous and Paleogene lacustrine and related nonmarine sedimentary and volcanic rocks in parts of the eastern Great Basin of Nevada and Utah, in Newman, G.W., and Goode, H.D., eds., Basin and Range symposium and Great Basin field conference: Rocky Mountain Association of Geologists, p. 305-312.

Fritz, W.H., 1968, Geologic map and sections of the southern Cherry Creek and northern Egan Ranges, White Pine County, Nevada: Nevada Bureau of Mines and Geology Map 35, scale 1:62,500.

Gehrels, G.E., Dickinson, W.R., Riley, B.C.D., Finney, S.C., and Smith, M.T., 2000, Detrital zircon geochronology of the Roberts Mountains allochthon, Nevada, in Soreghan, M.J., and Gehrels, G.E., eds., Paleozoic and Triassic paleogeography and tectonics of Western Nevada and Northern California: Boulder, Colo., Geological Society of America Special Paper 347, p. 19-42.

Gilluly, J., 1967, Geologic map of the Winnemucca quadrangle, Pershing and Humboldt Counties, Nevada: U.S. Geological Survey Geologic Quadrangle Map GQ-656, scale 1:62,500.

Gilluly, J., and Gates, O., 1965, Tectonic and igneous geology of the northern Shoshone Range Nevada: U.S. Geological Survey Professional Paper 465, 153 p.

Greene, R.C., Stewart, J.H., John, D.A., Hardyman, R.F., Silberling, N.J., and Sorensen, M.L., 1991, Geologic map of the Reno $1^{\circ}$ x $2^{\circ}$ quadrangle, Nevada and California: U.S. Geological Survey Miscellaneous Field Studies Map MF2154-A, scale 1:250,000.

Heidrick, T.L., 1965, Geology and ore deposits of the Ward mining district, White Pine County, Nevada: Boulder, Colo., University of Colorado, Masters thesis, 154 p.

Henry, C.D., 1996, Geologic map of the Bell Mountain quadrangle, Western Nevada: Nevada Bureau of Mines and Geology Field Studies Map 12, scale 1:24,000.

Hess, R.H., and Johnson, G., 1997, County digital geologic maps: Nevada Bureau of Mines and Geology Open-File Report 97-1, scale 1:250,000, CD-ROM. 
Hintze, L.F., and Axen, G.J., 1995, Geologic map of the Scarecrow Peak quadrangle, Washington County, Utah, and Lincoln County, Nevada: U.S. Geological Survey Geologic Quadrangle Map GQ-1759, scale 1:24,000.

Holdsworth, B.K., 1986, Later Paleozoic Radiolaria in thrust belts of Nevada: Journal of the Geological Society, London, v. 143 , p. 217.

Hose, R.K., 1983, Geologic map of the Cockalorum Wash quadrangle, Eureka and Nye Counties, Nevada: U.S. Geological Survey Miscellaneous Investigations Series Map I-1410, scale 1:31,680.

Hose, R.K., Blake, M.C., Jr., and Smith, R.M., 1976, Geology and mineral resources of White Pine County, Nevada: Nevada Bureau of Mines and Geology Bulletin 85, 105 p.

Hotz, P.E., and Willden, R., 1964, Geology and mineral deposits of the Osgood Mountains quadrangle, Humboldt County, Nevada: U.S. Geological Survey Professional Paper 431, 128 p.

John, D.A., 1987, Map showing the distribution and characteristics of plutonic rocks in the Tonopah $1^{\circ}$ by $2^{\circ}$ quadrangle, central Nevada: U.S. Geological Survey Miscellaneous Field Studies Map MF-1877-J, scale 1:250,000.

John, D.A., and Silberling, N.J., 1994, Geologic map of the La Plata Canyon quadrangle, Churchill County, Nevada: U.S. Geological Survey Geologic Quadrangle Map GQ-1710, scale 1:24,000.

Johnson, M.G., 1977, Geology and mineral deposits of Pershing County, Nevada: Nevada Bureau of Mines and Geology Bulletin 89, $115 \mathrm{p}$.

Jones, A.E., 1990, Geology and tectonic significance of terranes near Quinn River Crossing, Nevada, in Harwood, D.S., and Miller, M.M., eds., Paleozoic and early Mesozoic paleogeographic relations; Sierra Nevada, Klamath Mountains, and related terranes: Boulder, Colo., Geological Society of America Special Paper 255, p. 239-253.

Jones, A.E., 1991a, Sedimentary rocks of the Golconda terrane: Provenance and paleogeographic implications, in Cooper, J.D., and Stevens, C.H., eds., Paleozoic paleogeography of the Western United States-II: Los Angeles, Calif., Society of Economic Paleontologists and Mineralogists, Pacific Section, v. 2, p. 783-800.

Jones, A.E., 1991b, Tectonic significance of Paleozoic and Early Mesozoic terrane accretion in northern Nevada: Berkeley, University of California, Ph.D. dissertation, $256 \mathrm{p}$.

Jones, A.E., 1993, Northwest vergent folding in the Harmony Formation, north-central Nevada: Lower Paleozoic tectonics revisited: Geological Society of America Abstracts with Programs, v. 25, no. 5, p. 59.
Jones, A.E., 1997a, Geologic map of the Delvada Spring 7.5' quadrangle: Nevada Bureau of Mines and Geology Field Studies Map FS-13, scale 1:24,000.

Jones, A.E., 1997b, Geologic map of the Hot Springs Peak quadrangle and the southeastern part of the Little Poverty quadrangle, Nevada: Nevada Bureau of Mines and Geology Field Studies Map FS-14, scale 1:24,000.

Jones, D.L., Howell, D.G., Coney, P.J., and Monger, J.W.H., 1983, Recognition, character, and analysis of tectonostratigraphic terranes in western North America, in Hashimoto, M., and Uyeda, S., eds., Accretion tectonics in the circumpacific regions: Tokyo, Japan, Terra Scientific Publishing Company, p. 21-35.

Jones, D.L., Wrucke, C.T., Holdsworth, B., and Suczek, C.A., 1978, Revised ages of chert in the Roberts Mountains allochthon, northern Nevada: Geological Society of America Abstracts with Programs, v. 10, no. 3, p. 111.

Jory, J., 2002, Stratigraphy and host rock controls of gold deposits on the northern Carlin trend, in Thompson, T.B., Teal, L., and Meeuwig, R.O., eds., Gold deposits of the Carlin Trend: Nevada Bureau of Mines and Geology Bulletin 111, p. 20-45.

Ketner, K.B., 1986, Eureka Quartzite in Mexico(?)—Tectonic implications: Geology, v. 14, no. 12, p. 1027-1030.

Ketner, K.B., 1990, Geologic map of the Elko Hills, Elko County, Nevada: U.S. Geological Survey Miscellaneous Investigations Series Map I-2082, scale 1:24,000.

Ketner, K.B., 1998, Geologic map of the southern Independence Mountains, Elko County, Nevada: U.S. Geological Survey Geologic Investigations Series I-2629, scale 1:24,000.

Ketner, K.B., Crafford, A.E.J., Harris, A.G., Repetski, J.E., and Wardlaw, B.R., 2005, Late Devonian to Mississippian arkosic rock derived from a granitic terrane in northwestern Nevada adds a new dimension to the Antler orogeny, in Rhoden, H.N., Steiniger, R.C., and Vikre, P.G., eds., Geological Society of Nevada Symposium 2005: Window to the World: Reno, Geological Society of Nevada, v. 1, p. 135-145.

Ketner, K.B., and Evans, J.G., 1988, Geologic map of the Peko Hills, Elko County, Nevada: U.S. Geological Survey Miscellaneous Investigations Series Map I-1902, scale $1: 24,000$.

Ketner, K.B., Murchey, B.L., Stamm, R.G., and Wardlaw, B.R., 1993, Paleozoic and Mesozoic Rocks of Mount Ichabod and Dorsey Canyon, Elko County, NevadaEvidence for Post-Early Triassic emplacement of the Roberts Mountains and Golconda allochthons: U.S. Geological Survey Bulletin 1988-D, 12 p. 
Ketner, K.B., and Ross, R.J., Jr., 1990, Geologic map of the northern Adobe Range, Elko County, Nevada: U.S. Geological Survey Miscellaneous Investigations Series Map I-2081, scale 1:24,000.

Ketner, K.B., and Smith, J.F., Jr., 1963, Geology of the Railroad Mining District, Elko County, Nevada: U.S. Geological Survey Bulletin 1162-B, 27 p.

Kleinhampl, F.J., and Ziony, J.I., 1985, Geology of northern Nye County, Nevada: Nevada Bureau of Mines and Geology Bulletin 99A, 172 p.

Langenheim, R.L., Jr., and Larson, E.R., 1973, Correlation of Great Basin stratigraphic units: Nevada Bureau of Mines and Geology Bulletin 72, $36 \mathrm{p}$.

Lee, D.E., and Van Loenen, R.E., 1971, Hybrid granitoid rocks of the southern Snake Range, Nevada: U.S. Geological Survey Professional Paper 668, 48 p.

Leslie, S.A., Isaacson, P.E., Repetski, J.E., and Weideman, W.L., 1991, Upper plate rocks of the Roberts Mountains thrust, northern Independence Range, northeast Nevada: The Late Cambrian(?) to Middle Ordovician Snow Canyon Formation of the Valmy Group, in Cooper, J.D., and Stevens, C.H., eds., Paleozoic Paleogeography of the Western United States-II: Los Angeles, Calif., Society of Economic Paleontologists and Mineralogists, Pacific Section, v. 2, p. 475-486.

Longwell, C.R., Pampeyan, E.H., Bowyer, B., and Roberts, R.J., 1965, Geology and mineral deposits of Clark County, Nevada: Nevada Bureau of Mines and Geology Bulletin 62, 218 p.

Loucks, M.D., Tingey, D.G., Best, M.G., Christiansen, E.H., and Hintze, L.F., 1989, Geologic map of the Fortification Range, Lincoln and White Pine Counties, Nevada: U.S. Geological Survey Miscellaneous Investigations Series Map I-1866, scale 1:50,000.

Lovejoy, D.W., 1959, Overthrust Ordovician and the Nannie's Peak intrusive, Lone Mountain, Elko County, Nevada: Geological Society of America Bulletin, v. 70, p. 539-563.

Lupe, R., and Silberling, N.J., 1985, Genetic relationship between Lower Mesozoic continental strata of the Colorado Plateau and marine strata of the western Great Basin: Significance for accretionary history of Cordilleran lithotectonic terranes, in Howell, D.G., ed., Tectonostratigraphic terranes of the circum-pacific region: Houston, Texas, Circum-Pacific Council for Energy and Mineral Resources, Earth Science Series, no. 1, p. 263-271.

Lush, A.P., McGrew, A.J., Snoke, A.W., and Wright, J.E., 1988, Allochthonous Archean basement in the northern East Humboldt Range, Nevada: Geology, v. 16, no. 4, p. 349-353.
Madden-McGuire, D.J., 1991, Stratigraphy of the limestonebearing part of the Lower Cambrian to Lower Ordovician Preble Formation near its type locality, Humboldt County, North-Central Nevada, in Raines, G.L., Lisle, R.E., Schafer, R.W., and Wilkinson, W.H., eds., Geology and ore deposits of the Great Basin: Reno, Nev., Geological Society of Nevada, Symposium Proceedings, v. II, p. 875-893.

Madden-McGuire, D.J., Hutter, T.J., and Suczek, C.A., 1991, Late Cambrian-Early Ordovician microfossils from the allochthonous Harmony Formation at its type locality, northern Sonoma Range, Humboldt County, Nevada: Geological Society of America Abstracts with Programs, v. 23 , no. 2 , p. 75 .

Madden-McGuire, D.J., and Marsh, S.P., 1991, Lower Paleozoic host rocks in the Getchell gold belt: Several distinct allochthons or a sequence of continuous sedimentation(?): Geology, v. 19, no. 5, p. 489-492.

Martin, M.W., and Naumann, T.R., 1995, Geologic map of the Reveille quadrangle, Nevada: Nevada Bureau of Mines and Geology Map 104, scale 1:24,000.

McCollum, L.B., and McCollum, M., 1991, Paleozoic rocks of the Osgood Mountains, Nevada, in Raines, G.L., Lisle, R.E., Schafer, R.W., and Wilkinson, W.H., eds., Geology and ore deposits of the Great Basin: Reno, Nev., Geological Society of Nevada, Symposium Proceedings, v. II, p. 735-738.

McGrew, A.J., Peters, M.T., and Wright, J.E., 2000, Thermobarometric constraints on the tectonothermal evolution of the East Humboldt Range metamorphic core complex, Nevada: Geological Society of America Bulletin, v. 112 , no. 1 , p. 45-60.

McKee, E.H., 1976a, Geologic map of the Austin quadrangle, Lander County, Nevada: U.S. Geological Survey Geologic Quadrangle Map GQ-1307, scale 1:62,500.

McKee, E.H., 1976b, Geology of the northern part of the Toquima Range, Lander, Eureka, and Nye Counties, Nevada: U.S. Geological Survey Professional Paper 931, $49 \mathrm{p}$.

McKee, E.H., and Burke, D.B., 1972, Fission-track age bearing on the Permian-Triassic boundary and time of the Sonoma Orogeny in north-central Nevada: Geological Society of America Bulletin, v. 83, p. 1949-1952.

Means, W.D., 1962, Structure and stratigraphy in the central Toiyabe Range, Nevada: California University Publications of the Geological Sciences, v. 42, no. 2, p. 71-110.

Miller, E.L., Gans, P.B., Grier, S.P., Huggins, C.C., and Lee, J., 1999, Geologic map of the Old Mans Canyon quadrangle, Nevada: Nevada Bureau of Mines and Geology Field Studies Map 21, scale 1:24,000. 
Miller, E.L., Grier, S.P., and Brown, J.L., 1995, Geologic map of the Lehman Caves quadrangle, White Pine County, Nevada: U.S. Geological Survey Geologic Quadrangle Map GQ-1758, scale 1:24,000.

Miller, E.L., Holdsworth, B.K., Whiteford, W.B., and Rodgers, D., 1984, Stratigraphy and structure of the Schoonover sequence, northeastern Nevada: Implications for Paleozoic plate-margin tectonics: Geological Society of America Bulletin, v. 95, no. 9, p. 1063-1076.

Miller, E.L., Kanter, L.R., Larue, D.K., Turner, R.J.W., Murchey, B.L., and Jones, D.L., 1982, Structural fabric of the Paleozoic Golconda allochthon, Antler Peak quadrangle, Nevada: Progressive deformation of an oceanic sedimentary assemblage: Journal of Geophysical Research, v. 87, no. B5, p. 3795-3804.

Miller, E.L., and Larue, D.K., 1983, Ordovician quartzite in the Roberts Mountains allochthon, Nevada: Deep sea fan deposits derived from cratonal North America, in Stevens, C.H., ed., Pre-Jurassic rocks in western North American suspect terranes: Los Angeles, Calif., Society of Economic Paleontologists and Mineralogists, Pacific Section, p. 91-102.

Moore, J.G., 1969, Geology and mineral deposits of Lyon, Douglas, and Ormsby Counties, Nevada: Nevada Bureau of Mines and Geology Bulletin 75, 45 p.

Mueller, K.J., 1993, Geologic map of the Windermere Hills, Northeastern Nevada: Nevada Bureau of Mines and Geology Field Studies Map 4, scale 1:24,000.

Muffler, L.J.P., 1964, Geology of the Frenchie Creek quadrangle, north-central Nevada: U.S. Geological Survey Bulletin 1179, 99 p.

Muller, S.W., Ferguson, H.G., and Roberts, R.J., 1951, Geology of the Mount Tobin quadrangle, Nevada: U.S. Geological Survey Geologic Quadrangle Map GQ-7, scale $1: 125,000$.

Murchey, B.L., 1990, Age and depositional setting of siliceous sediments in the upper Paleozoic Havallah sequence near Battle Mountain, Nevada: Implications for the paleogeography and structural evolution of the western margin of North America, in Harwood, D.S., and Miller, M.M., eds., Paleozoic and early Mesozoic paleogeographic relations; Sierra Nevada, Klamath Mountains, and related terranes: Boulder, Colo., Geological Society of America Special Paper 255, p. 137-155.

Neff, T.R., 1969, Petrology and structure of the Buffalo Mountain pluton (probably Late Permian), Humboldt County, Nevada: Palo Alto, Stanford University, Ph.D. dissertation, $210 \mathrm{p}$.
Nichols, K.M., and Silberling, N.J., 1977a, Depositional and tectonic significance of Silurian and Lower Devonian dolomites, Roberts Mountains and vicinity, east-central Nevada, in Stewart, J.H., Stevens, C.H., and Fritsche, A.E., eds., Paleozoic paleogeography of the western United States: Los Angeles, Calif., Society of Economic Paleontologists and Mineralogists, Pacific Section, Pacific Coast Paleogeography Symposium 1, p. 217-240.

Nichols, K.M., and Silberling, N.J., 1977b, Stratigraphy and depositional history of the Star Peak Group (Triassic), northwestern Nevada: Geological Society of America Special Paper 178, 73 p.

Noble, P.J., Cellura, B.R., and Cluer, J.K., 1999, Revision of structural and stratigraphic relationships in the Roberts Mountains allochthon, Nevada, based on radiolarian chert: Geological Society of America Abstracts with Programs, v. 31, no. 7, p. A-355.

Noble, P.J., and Finney, S.C., 1999, Recognition of fine-scale imbricate thrusts in lower Paleozoic orogenic belts-An example from the Roberts Mountains allochthon, Nevada: Geology, v. 27, no. 6, p. 543-546.

Noble, P.J., Finney, S.C., and Cluer, J.K., 2000, Revised stratigraphy of the Roberts Mountains allochthon and structural implications: Geological Society of America Abstracts with Programs, v. 32, no. 7, p. A-383.

Nolan, T.B., 1928, A late Paleozoic positive area in Nevada: American Journal of Science, v. 16, no. 92, p. 153-161.

Nolan, T.B., Merriam, C.W., and Blake, M.C., Jr., 1974, Geologic map of the Pinto Summit quadrangle, Eureka and White Pine Counties, Nevada: U.S. Geological Survey Miscellaneous Investigations Series Map I-793, scale 1:31,680.

Nolan, T.B., Merriam, C.W., and Brew, D.A., 1971, Geologic map of the Eureka quadrangle, Eureka and White Pine Counties, Nevada: U.S. Geological Survey Miscellaneous Geologic Investigations Series Map I-612, scale 1:31,680.

Oldow, J.S., 1981, Structure and stratigraphy of the Luning allochthon and the kinematics of allochthon emplacement, Pilot Mountains, west-central Nevada: Geological Society of America Bulletin, part I, v. 92, p. 888-911.

Oldow, J.S., 1984a, Evolution of a late Mesozoic back-arc fold and thrust belt, northwestern Great Basin, U.S.A.: Tectonophysics, v. 102, p. 245-274.

Oldow, J.S., 1984b, Spatial variability in the structure of the Roberts Mountains allochthon, western Nevada: Geological Society of America Bulletin, v. 95, no. 2, p. 174-185.

Oldow, J.S., and Bartel, R.L., 1987, Early to Middle(?) Jurassic extensional tectonism in the western Great Basin: Growth faulting and synorogenic deposition of the Dunlap Formation: Geology, v. 15, no. 8, p. 740-743. 
Oldow, J.S., Satterfield, J.I., and Silberling, N.J., 1993, Jurassic to Cretaceous transpressional deformation in the Mesozoic marine province of the northwestern Great Basin, in Lahren, M.M., Trexler, J.H., Jr., and Spinosa, C., eds., Crustal evolution of the Great Basin and Sierra Nevada: University of Nevada, Reno, Cordilleran/Rocky Mountain Section, Geological Society of America Guidebook, p. 129-166.

Oversby, B., 1972, Thrust sequences in the Windermere Hills, northeastern Elko County, Nevada: Geological Society of America Bulletin, v. 83, no. 9, p. 2677-2688.

Page, B.M., 1959, Geology of the Candelaria mining district, Mineral County, Nevada: Nevada Bureau of Mines Bulletin $56,67 \mathrm{p}$.

Page, W.R., Lundstrom, S.C., Harris, A.G., Langenheim, V.E., Workman, J.B., Mahan, S.A., Paces, J.B., Dixon, G.L., Rowley, P.D., Burchfiel, B.C., Bell, J.W., and Smith, E.I., 2005, Geologic and geophysical maps of the Las Vegas $30^{\prime}$ x 60' quadrangle, Clark and Nye Counties, Nevada and Inyo County, California: U.S. Geological Survey Scientific Investigations Map 2814, scale 1:100,000.

Peters, S.G., 1997a, Structural transect across the central Carlin trend, Eureka County, Nevada: U.S. Geological Survey Open-File Report 97-55, 40 p.

Peters, S.G., 1997b, Structural transect across the northcentral Carlin trend, Eureka County, Nevada: U.S. Geological Survey Open-File Report 97-83, 41 p.

Peters, S.G., 1997c, Structural transect across the southern Carlin trend, Elko and Eureka Counties, Nevada: U.S. Geological Survey Open-File Report 97-31, 27 p.

Peters, S.G., Armstrong, A.K., Harris, A.G., Oscarson, R.L., and Noble, P.J., 2003, Biostratigraphy and structure of Paleozoic host rocks and their relationship to Carlin-type gold deposits in the Jerritt Canyon mining district, Nevada: Economic Geology, v. 98, no. 2, p. 317-337.

Poole, F.G., and Wardlaw, B.R., 1978, Candelaria (Triassic) and Diablo (Permian) Formations in southern Toquima Range, central Nevada, in Howell, D.G., and McDougall, K.A., eds., Mesozoic paleogeography of the western United States: Los Angeles, Calif., Society of Economic Paleontologists and Mineralogists, Pacific Section, Pacific Coast Paleogeography Symposium 2, p. 271-276.

Riva, J., 1970, Thrusted Paleozoic rocks in the northern and central HD Range, northeastern Nevada: Geological Society of America Bulletin, v. 81, no. 9, p. 2689-2716.

Roberts, R.J., 1951, Geology of the Antler Peak quadrangle, Nevada: U.S. Geological Survey Geologic Quadrangle Map GQ-10, scale 1:62,500.
Roberts, R.J., 1964, Stratigraphy and structure of the Antler Peak quadrangle, Humboldt and Lander Counties, Nevada: U.S. Geological Survey Professional Paper 459-A, 93 p.

Roberts, R.J., Hotz, P.E., Gilluly, J., and Ferguson, H.G., 1958, Paleozoic rocks of north-central Nevada: Bulletin of the American Association of Petroleum Geologists, v. 42, no. 12, p. 2813-2857.

Roberts, R.J., Montgomery, K., and Lehner, R.E., 1967, Geology and mineral resources of Eureka County, Nevada: Nevada Bureau of Mines and Geology Bulletin 64, 152 p.

Ross, D.C., 1961, Geology and mineral deposits of Mineral County, Nevada: Nevada Bureau of Mines and Geology Bulletin 58, 98 p.

Rowley, R.B., 1980, Geology and mineral deposits of the Lodi Hills, Nye County, Nevada: Salt Lake City, Brigham Young University, Geology Studies, v. 27, p. 141-151.

Russell, B.J., 1984, Mesozoic geology of the Jackson Mountains, northwestern Nevada: Geological Society of America Bulletin, v. 95, no. 3, p. 313-323.

Sayeed, U.A., 1973, Petrology and structure of Kern Mountains plutonic complex, White Pine County, Nevada, and Juab County, Utah: Lincoln, University of Nebraska, Ph.D. dissertation, $134 \mathrm{p}$.

Shawe, D.R., 2002, Geologic map of part of the southern Toquima Range and adjacent areas, Nye County, Nevada: U.S. Geological Survey Miscellaneous Field Studies Map MF-2327-A, scale 1:48,000.

Silberling, N.J., 1973, Geologic events during PermianTriassic time along the Pacific margin of the United States, in Logan, A., and Hills, L.V., eds., The Permian and Triassic systems and their mutual boundary: Calgary, Alberta, Canadian Society of Petroleum Geologists Memoir 2, p. 345-362.

Silberling, N.J., 1975, Age relationships of the Golconda thrust fault, Sonoma Range, North-Central Nevada: Boulder, Colo., Geological Society of America Special Paper 163, 28 p.

Silberling, N.J., 1984, Map showing localities and correlation of age-diagnostic Lower Mesozoic megafossils, Walker Lake $1^{\circ} \times 2^{\circ}$ quadrangle, Nevada and California: U.S. Geological Survey Miscellaneous Field Studies Map MF1382-O, scale 1:250,000.

Silberling, N.J., 1991, Allochthonous terranes of Western Nevada, current status, in Raines, G.L., Lisle, R.E., Schafer, R.W., and Wilkinson, W.H., eds., Geology and ore deposits of the Great Basin: Reno, Nev., Geological Society of Nevada, Symposium Proceedings, v. 1, p. 101-102. 
Silberling, N.J., and John, D.A., 1989, Geologic map of preTertiary rocks of the Paradise Range and southern Lodi Hills, west-central Nevada: U.S. Geological Survey Miscellaneous Field Studies Map MF-2062, scale 1:24,000.

Silberling, N.J., Jones, D.L., Blakely, R.J., and Howell, D.G., 1987, Lithotectonic terrane map of the western conterminous United States: U.S. Geological Survey Miscellaneous Field Studies Map MF-1874-C, scale 1:2,500,000.

Silberling, N.J., Jones, D.L., Monger, J.W.H., and Coney, P.J., 1992, Lithotectonic terrane map of the North American cordillera: U.S. Geological Survey Miscellaneous Investigations Series Map I-2176, scale 1:5,000,000.

Silberling, N.J., and Roberts, R.J., 1962, Pre-Tertiary stratigraphy and structure of northwestern Nevada: Boulder, Colo., Geological Society of America Special Paper 72, 58 p.

Silberling, N.J., and Wallace, R.E., 1967, Geologic map of the Imlay quadrangle, Pershing County, Nevada: U.S. Geological Survey Geologic Quadrangle Map GQ-666, scale 1:62,500.

Silberling, N.J., and Wallace, R.E., 1969, Stratigraphy of the Star Peak Group (Triassic) and overlying lower Mesozoic rocks, Humboldt Range, Nevada: U.S. Geological Survey Professional Paper 592, 50 p.

Sloan, J., Henry, C.D., Hopkins, M., Ludington, S., Zartman, R.E., Bush, C.A., and Abston, C., 2003, National geochronological database (revised ed.): U.S. Geological Survey Open-File Report 03-236, CD-ROM, 6 tables.

Smith, J.F., Jr., and Ketner, K.B., 1976, Stratigraphy of post-Paleozoic rocks and summary of resources in the Carlin-Piñon Range area, Nevada: U.S. Geological Survey Professional Paper 867-B, 48 p.

Smith, J.F., Jr., and Ketner, K.B., 1978, Geologic map of the Carlin-Piñon Range area, Elko and Eureka Counties, Nevada: U.S. Geological Survey Miscellaneous Investigations Series Map I-1028, scale 1:62,500.

Smith, J.F., Jr., Ketner, K.B., Hernandez, G.X., Harris, A.G., Stamm, R.G., and Smith, M.C., 1990, Geologic map of the Summer Camp quadrangle and part of the Black Butte quadrangle, Elko County, Nevada: U.S. Geological Survey Miscellaneous Investigations Series Map I-2097, scale $1: 24,000$.

Smith, M., and Gehrels, G., 1994, Detrital zircon geochronology and the provenance of the Harmony and Valmy Formations, Roberts Mountains allochthon, Nevada: Geological Society of America Bulletin, v. 106, p. 968-979.

Speed, R.C., 1977a, Excelsior Formation, west-central Nevada: Stratigraphic appraisal, new divisions, and paleogeographic interpretations, in Stewart, J.H., Stevens, C.H., and Fritsche, A.E., eds., Paleozoic paleogeography of the western United States: Los Angeles, Calif., Society of Economic Paleontologists and Mineralogists, Pacific Section, Pacific Coast Paleogeography Symposium 1, p. 325-336.

Speed, R.C., 1977b, Island arc and other paleogeographic terranes of late Paleozoic age in the western Great Basin, in Stewart, J.H., Stevens, C.H., and Fritsche, A.E., eds., Paleozoic paleogeography of the western United States: Los Angeles, Calif., Society of Economic Paleontologists and Mineralogists, Pacific Section, Pacific Coast Paleogeography Symposium 1, p. 349-362.

Speed, R.C., and Jones, T.A., 1969, Synorogenic quartz sandstone in the Jurassic mobile belt of western Nevada: Boyer Ranch Formation: Geological Society of America Bulletin, v. 80 , no. 12 , p. 2551-2584.

Speed, R.C., MacMillan, J.R., Poole, F.G., and Kleinhampl, F.J., 1977, Diablo Formation, central-western Nevada; composite of deep and shallow water upper Paleozoic rocks, in Stewart, J.H., Stevens, C.H., and Fritsche, A.E., eds., Paleozoic paleogeography of the western United States: Los Angeles, Calif., Society of Economic Paleontologists and Mineralogists, Pacific Section, Pacific Coast Paleogeography Symposium 1, p. 301-313.

Speed, R.C., Silberling, N.J., Elison, M.W., Nichols, K.M., and Snyder, W.S., 1989, Early Mesozoic tectonics of the western Great Basin, Nevada: Washington, D.C., American Geophysical Union, International Geological Congress Field Trip Guidebook T122, 54 p.

Stahl, S.D., 1987, Mesozoic structural features in Sonoma Canyon, Sonoma Range, Humboldt and Pershing Counties, Nevada, in Hill, M., ed., Geological Society of America Centennial Field Guide-Cordilleran Section: Boulder, Colo., Geological Society of America, v. 1, p. 85-90.

Stewart, J.H., 1972, Initial deposits in the Cordilleran geosyncline: Evidence of a late Precambrian (<850 m.y.) continental separation: Geological Society of America Bulletin, v. 83, no. 5, p. 1345-1360.

Stewart, J.H., 1980, Geology of Nevada-A discussion to accompany the geologic map of Nevada: Nevada Bureau of Mines and Geology Special Publication 4, 136 p.

Stewart, J.H., and Carlson, J.E., 1978, Geologic map of Nevada: U.S. Geological Survey, scale 1:500,000.

Stewart, J.H., MacMillan, J.R., Nichols, K.M., and Stevens, C.H., 1977, Deep-water upper Paleozoic rocks in northcentral Nevada-A study of the type area of the Havallah Formation, in Stewart, J.H., Stevens, C.H., and Fritsche, A.E., eds., Paleozoic paleogeography of the western United States: Los Angeles, Calif., Society of Economic Paleontologists and Mineralogists, Pacific Section, Pacific Coast Paleogeography Symposium 1, p. 337-347. 
Stewart, J.H., and McKee, E.H., 1968, Geologic map of southeastern part of Lander County, Nevada: U.S. Geological Survey Open-File Report 68-260, scale 1:62,500.

Stewart, J.H., McKee, E.H., and Stager, H.K., 1977, Geology and mineral deposits of Lander County, Nevada: Nevada Bureau of Mines and Geology Bulletin 88, 106 p.

Stewart, J.H., Murchey, B.L., Jones, D.L., and Wardlaw, B.R., 1986, Paleontologic evidence for complex tectonic interlayering of Mississippian to Permian deep-water rocks of the Golconda allochthon in Tobin Range, north-central Nevada: Geological Society of America Bulletin, v. 97, no. 9, p. 1122-1132.

Stewart, J.H., and Palmer, A.R., 1967, Callaghan window-A newly discovered part of the Roberts thrust, Toiyabe Range, Lander County, Nevada: U.S. Geological Survey Professional Paper 575-D, p. 56-63.

Theodore, T.G., 1991, Preliminary geologic map of the North Peak quadrangle, Humboldt and Lander Counties, Nevada: U.S. Geological Survey Open-File Report 91-429, scale $1: 24,000$.

Theodore, T.G., 1994, Preliminary geologic map of the Valmy quadrangle, Humboldt County, Nevada: U.S. Geological Survey Open-File Report 91-430, scale 1:24,000.

Theodore, T.G., Moring, B.C., Harris, A.G., Armstrong, A.K., and Finney, S.C., 2003, Geologic map of the Beaver Peak quadrangle, Elko and Eureka Counties, Nevada: Nevada Bureau of Mines and Geology Map 143, scale 1:24,000.

Theodore, T.G., Murchey, B.L., Hanger, R.A., Strong, E.E., and Ashinhurst, R.T., 1994, Preliminary geologic map of the Snow Gulch quadrangle, Humboldt and Lander Counties, Nevada: U.S. Geological Survey Open-File Report 94-436, scale 1:24,000.

Thompson, T.B., Teal, L., and Meeuwig, R.O., eds., 2002, Gold deposits of the Carlin Trend: Nevada Bureau of Mines and Geology Bulletin 111, 204 p.

Thorman, C.H., Brooks, W.E., Ketner, K.B., and Dubiel, R.F., 2003, Preliminary geologic map of the Oxley Peak area, Elko County, Nevada: Nevada Bureau of Mines and Geology Open-File Report 03-4, scale 1:24,000.

Thurber, J.E., 1982, Petrology and Cu-Mo mineralization of the Kennedy stock, East Range, Pershing County, Nevada: Fort Collins, Colorado State University, Masters thesis, $101 \mathrm{p}$.

Trexler, J.H., Jr., Cashman, P.H., Snyder, W.S., and Davydov, V.I., 2004, Late Paleozoic tectonism in Nevada: Timing, kinematics, and tectonic significance: Geological Society of America Bulletin, v. 116, no. 5/6, p. 525-538.

Tschanz, C.M., and Pampeyan, E.H., 1970, Geology and mineral deposits of Lincoln County, Nevada: Nevada Bureau of Mines and Geology Bulletin 73, 188 p.
Wallace, A.R., 1993, Geologic map of the Snowstorm Mountains and vicinity, Elko and Humboldt Counties, Nevada: U.S. Geological Survey Miscellaneous Investigations Series Map I-2394, scale 1:50,000.

Wallace, R.E., Silberling, N.J., Irwin, W.P., and Tatlock, D.B., 1969, Geologic map of the Buffalo Mountain quadrangle, Pershing and Churchill Counties, Nevada: U.S. Geological Survey Geologic Quadrangle Map GQ-821, scale 1:62,500.

Wallace, R.E., Tatlock, D.B., and Silberling, N.J., 1960, Intrusive rocks of Permian and Triassic age in the Humboldt Range, Nevada: U.S. Geological Survey Professional Paper 400-B, p. B291-B293.

Wallace, R.E., Tatlock, D.B., Silberling, N.J., and Irwin, W.P., 1969, Geologic map of the Unionville quadrangle, Pershing County, Nevada: U.S. Geological Survey Geologic Quadrangle Map GQ-820, scale 1:62,500.

Watkins, R., and Browne, Q.J., 1989, An Ordovician continental-margin sequence of turbidite and seamount deposits in the Roberts Mountains allochthon, Independence Range, Nevada: Geological Society of America Bulletin, v. 101, no. 5, p. 731-741.

Wells, J.D., and Elliott, J.E., 1971, Geochemical reconnaissance of the Cortez-Buckhorn area, southern Cortez Mountains, Nevada: U.S. Geological Survey Bulletin 1312-P, 18 p.

Whitebread, D.H., 1994, Geologic map of the Dun Glen quadrangle, Pershing County, Nevada: U.S. Geological Survey Miscellaneous Investigations Series Map I-2409, scale 1:48,000.

Whitebread, D.H., and John, D.A., 1992, Geologic Map of the Tonopah $1^{\circ}$ by $2^{\circ}$ quadrangle, Central Nevada: U.S. Geological Survey Miscellaneous Field Studies Map MF1877-A, scale 1:250,000.

Willden, R., 1964, Geology and mineral deposits of Humboldt County, Nevada: Nevada Bureau of Mines and Geology Bulletin 59, 154 p.

Willden, R., and Speed, R.C., 1974, Geology and mineral deposits of Churchill County, Nevada: Nevada Bureau of Mines and Geology Bulletin 83, 95 p.

Wrucke, C.T., 1974, Geologic map of the Gold AcresTenabo area, Shoshone Range, Lander County, Nevada: U.S. Geological Survey Miscellaneous Field Studies Map MF-647, scale 1:15,840.

Wyld, S.J., 1990, Paleozoic and Mesozoic rocks of the Pine Forest Range, northwest Nevada, and their relation to volcanic arc assemblages of the western U.S. Cordillera, in Harwood, D.S., and Miller, M.M., eds., Paleozoic and early Mesozoic paleogeographic relations; Sierra Nevada, Klamath Mountains, and related terranes: Boulder, Colo., Geological Society of America Special Paper 255, p. 219-237. 
Wyld, S.J., 2002, Structural evolution of a Mesozoic backarc fold-and-thrust belt in the U.S. Cordillera: New evidence from northern Nevada: Geological Society of America Bulletin, v. 114, no. 11, p. 1452-1468.

Zientek, M.L., Sidder, G.B., and Zierenberg, R.A., 2004, Platinum-Group-Element (PGE) potential of the Humboldt mafic complex, Nevada, Assessment of metallic mineral resources in the Humboldt River Basin, northern Nevada: U.S. Geological Survey Bulletin 2218, p. 115-124.

\section{Acknowledgments}

A compilation and reinterpretation of this scope would not be possible without a great deal of input from many people. The author is greatly indebted to the following people for their invaluable assistance, insight and important information; Ron Hess and Gary Johnson for the original digital work on the county maps; Norm Silberling, Mesozoic and Paleozoic terranes; John Oldow, Mesozoic terranes; Alan Wallace, Dave John, and Chris Henry, Tertiary volcanic rocks; Ed du Bray and Steve Ludington, Intrusive rocks; Keith Howard, Metamorphic rocks; Anita Harris, Conodonts; and David Jones, Paleozoic and Mesozoic terranes and tectonics. Most thoughtful and thorough reviews of geologic content by Ted Theodore, digital content by Doug Yager, geologic names review by Tom Judkins, and final editing by Gayle Dumonceaux are gratefully acknowledged. Paul Denning provided critical GIS support in the final stages of the map, and Gary Raines offered valuable insight and advice for the digital content and metadata. The author takes full responsibility for errors and omissions, and is grateful to the many individuals whose insight and observations provided the ingredients for revised interpretations presented herein. Financial support that made this project possible was provided by AngloGold, North America; Anita Harris; Nevada Bureau of Mines and Geology; and Al Hofstra and the Metallogeny of the Great Basin team of the U.S. Geological Survey. Thank you one and all. 